\title{
MYOP: um arcabouço para predição de genes ab initio
}

ANDRÉ YoshiAKI KASHIWABARA

\author{
DISSERTAÇÃO APRESENTADA \\ $\mathrm{AO}$ \\ INSTITUTO DE MATEMÁTICA E ESTATÍSTICA \\ DA \\ UNIVERSIDADE DE SÃO PAULO \\ PARA \\ OBTENÇÃO DO GRAU DE MESTRE \\ EM \\ CIÊNCIAS
}

Programa: Ciência da Computação

Orientador: Prof. Dr. Alan Mitchell Durham

Durante a elaboração deste trabalho o autor recebeu apoio financeiro do CAPES

São Paulo, março de 2007 


\title{
MYOP: um arcabouço para predição de genes ab initio
}

\author{
Este exemplar corresponde à redação \\ final da dissertação/tese devidamente corrigida \\ e defendida por André Yoshiaki Kashiwabara \\ e aprovada pela Comissão Julgadora.
}

Banca Examinadora:

- Prof. Dr. Alan Mitchell Durham - IME-USP.

- Prof. Dr. Arthur Gruber - ICB-USP.

- Prof. Dr. Marco Dimas Gubitoso - IME-USP. 


\section{Agradecimentos}

Ao meu orientador e amigo, Prof. Dr. Alan Mitchell Durham, pelos ensinamentos sobre os aspectos da vida acadêmica e por ajudar-me a estudar nesta área de pesquisa. Ao Prof. Dr. Arthur Gruber que me recebeu durante a iniciação científica e que continua me ajudando com diversos conselhos.

Ao nosso grupo de estudo, especialmente para a amiga Ariane Machado-Lima pelos conselhos e dicas importantes, ao Daniel Vieira pela ajuda no início do mestrado, e ao amigo Ricardo Abe pelas várias discussões interessantes.

Quero agradecer a toda turma do Laboratório Bioinfo e de Processamento de Imagens do IME-USP, especialmente para Jesús Pascual Mena-Chalco pela troca de informações sobre o assunto de predição de genes. Ao David da Silva Pires pela amizade e por incentivar a praticar esportes. Um agradecimento especial para os administradores da rede Vision.

Gostaria de agradecer aos meus pais e irmãs e dedico esta dissertação para eles.

Finalmente, quero agradecer a CAPES pelo apoio financeiro durante esta pesquisa. 


\section{Resumo}

A demanda por abordagens eficientes para o problema de reconhecer a estrutura de cada gene numa seqüência genômica motivou a implementação de um grande número de programas preditores de genes. Fizemos uma análise dos programas de sucesso com abordagem probabilística e reconhecemos semelhanças na implementação dos mesmos. A maior parte desses programas utiliza a cadeia oculta generalizada de Markov (GHMM - generalized hidden Markov model) como um modelo de gene. Percebemos que muitos preditores têm a arquitetura da GHMM fixada no código-fonte, dificultando a investigação de novas abordagens. Devido a essa dificuldade e pelas semelhanças entre os programas atuais, implementamos o sistema MYOP (Make Your Own Predictor) que tem como objetivo fornecer um ambiente flexível o qual permite avaliar rapidamente cada modelo de gene. Mostramos a utilidade da ferramenta através da implementação e avaliação de 96 modelos de genes em que cada modelo é formado por um conjunto de estados e cada estado tem uma distribuição de duração e um outro modelo probabilístico. Verificamos que nem sempre um modelo probabilístico mais sofisticado fornece um preditor melhor, mostrando a relevância das experimentações e a importância de um sistema como o MYOP.

Palavras chaves: predição de genes, bioinformática, cadeia de Markov oculta generalizada. 


\section{Abstract}

The demand for efficient approaches for the gene structure prediction has motivated the implementation of different programs. In this work, we have analyzed successful programs that apply the probabilistic approach. We have observed similarities between different implementations, the same mathematical framework called generalized hidden Markov chain (GHMM) is applied. One problem with these implementations is that they maintain fixed GHMM architectures that are hard-coded. Due to this problem and similarities between the programs, we have implemented the MYOP framework (Make Your Own Predictor) with the objective of providing a flexible environment that allows the rapid evaluation of each gene model. We have demonstrated the utility of this tool through the implementation and evaluation of 96 gene models in which each model has a set of states and each state has a duration distribution and a probabilistic model. We have shown that a sophisticated probabilistic model is not sufficient to obtain better predictor, showing the experimentation relevance and the importance of a system as MYOP.

Key words: gene prediction, Bioinformatics, generalized hidden Markov model. 


\section{Sumário}

$\begin{array}{ll}\text { Agradecimentos } & \text { v }\end{array}$

Resumo vii

$\begin{array}{ll}\text { Abstract } & \text { ix }\end{array}$

Lista de Figuras $\quad$ xiii

$\begin{array}{ll}\text { Lista de Tabelas } & \text { xvi }\end{array}$

1 Introdução 1

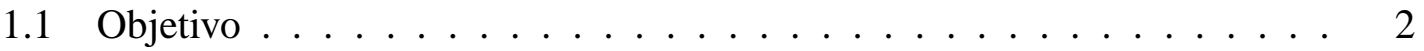

1.2 Organização do trabalho ..................... 3

2 Conceitos biológicos 5

2.1 A síntese de RNA . . . . . . . . . . . . . . . . . 5

2.2 Splicing do pre-mRNA mediado pelo spliceossomo . . . . . . . . . 6

2.3 A síntese de proteína . . . . . . . . . . . . . . . . . . 8

2.4 Estruturas dos genes de eucariotos e procariotos . . . . . . . . . . . 9

3 Abordagens para predição de genes 13

3.1 Informações utilizadas para a predição de genes . . . . . . . . . . . . . . 14

3.1.1 Sensores de sinais $\ldots \ldots \ldots \ldots$

3.1.2 Reconhecimento de sinais biológicos . . . . . . . . . . . 15

3.1.3 Sensores de conteúdo intrínsecos . . . . . . . . . . . . . . 16

3.1.4 Reconhecimento de regiões codificadoras . . . . . . . . . . . 17 
3.1.5 Cadeia oculta generalizada de Markov e predição de genes . . . . 18

3.2 Arquitetura dos preditores atuais . . . . . . . . . . . . 22

4 Modelos probabilísticos para a predição de genes 29

4.1 Cadeia de Markov . . . . . . . . . . . . . . . . . . . . 29

4.1.1 Weight matrix model ................ 31

4.1 .2 Weight array method ............... 33

4.1.3 Cadeia de Markov com periodicidade três . . . . . . . . . . . 34

4.1.4 Cadeia de Markov com ordem maior . . . . . . . . . . . . 35

4.2 Cadeia interpolada de Markov . . . . . . . . . . . . . . . 36

4.3 Cadeia oculta de Markov . . . . . . . . . . . . . . . . . 36

4.3.1 Cálculo da probabilidade da seqüência dado o modelo . . . . . . 38

4.3.2 Algoritmo de Viterbi . . . . . . . . . . . . . . . 39

4.4 Cadeia oculta generalizada de Markov . . . . . . . . . . . . . . . . 40

4.4.1 Cálculo da probabilidade da seqüência dado o modelo . . . . . . 42

4.4 .2 Algoritmo de Viterbi . . . . . . . . . . . . . . . 42

5 O sistema MYOP 45

5.1 Utilizando o MYOP . . . . . . . . . . . . . . . . 46

5.2 Componentes do MYOP . . . . . . . . . . . . . . . . . . 49

5.3 Validação dos modelos e teste de unidade . . . . . . . . . . . . . . 50

5.4 Detalhes de implementação do MYOP . . . . . . . . . . . . . . . . 51

5.4.1 Fábricas de distribuições discretas de probabilidade . . . . . . . . 52

5.4 .2 Fábricas de alfabetos . . . . . . . . . . . . . . 52

5.4.3 Construtores de modelos probabilísticos . . . . . . . . . 53

5.4 .4 MYOP e Python .................... 53

5.4 .5 Ferramentas utilizadas $\ldots \ldots \ldots \ldots 4$

6 Um exemplo de uso do MYOP

6.1 Amostra de genes . . . . . . . . . . . . . . . 56 
6.2 Topologias testadas $\ldots \ldots \ldots \ldots$. . . . . . . . . . . . . . . . .

6.3 Sensores de conteúdo avaliados . . . . . . . . . . . . . . . . 56

6.4 Sensores de sinais avaliados $\ldots \ldots \ldots \ldots$

6.5 Duração dos estados . . . . . . . . . . . . . . . . 58

6.6 Modelos de genes avaliados . . . . . . . . . . . . . . . . 60

6.7 Avaliação dos modelos de genes . . . . . . . . . . . . . . . . . 60

6.8 Resultados . . . . . . . . . . . . . . . . . . . 60

6.9 Discussão e Conclusão . . . . . . . . . . . . . . . . . . . . . . . . . 62

$\begin{array}{lll}7 & \text { Conclusão } & 67\end{array}$

7.1 Trabalhos futuros . . . . . . . . . . . . . . 68

$\begin{array}{ll}\text { A Utilizando o MYOP } & 77\end{array}$

A.1 Programa build_model . . . . . . . . . . . . . . . . . 77

A.2 Gerando seqüências simuladas . . . . . . . . . . . . . . 77

A.3 Configurando uma GHMM . . . . . . . . . . . . . . . 78

A.4 Encontrando a estrutura do gene . . . . . . . . . . . . . . 81

A.5 Outros programas do MYOP . . . . . . . . . . . . . . . 82

B Gerando seqüências por simulação dos modelos $\quad 83$

$\begin{array}{llr}\text { C Avaliação entre preditores de genes } & 87\end{array}$

C.1 Medidas de exatidão da predição de genes . . . . . . . . . . . . . . . 87

$\begin{array}{lr}\text { D Poster ISMB } 2006 & 89\end{array}$ 


\section{Lista de Figuras}

2.1 A transcrição em organismos eucariotos. . . . . . . . . . . . . . 6

2.2 Splicing pelo spliceossomo . . . . . . . . . . . . . . 7

2.3 A maquinaria da tradução . . . . . . . . . . . . . . . . . . . . . . 9

2.4 RNA mensageiro de procarioto . . . . . . . . . . . . . . . . 10

2.5 Gene de eucarioto . . . . . . . . . . . . . . . . . . 11

3.1 Exemplo de uma GHMM simples . . . . . . . . . . . . . . . . . . . . 19

3.2 Exemplo de uma GHMM para predição de genes . . . . . . . . . . . . 20

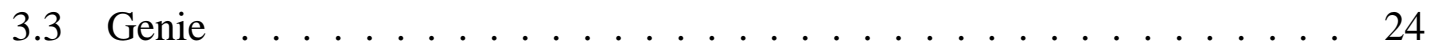

3.4 Genscan . . . . . . . . . . . . . . . . . 25

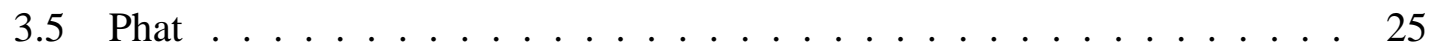

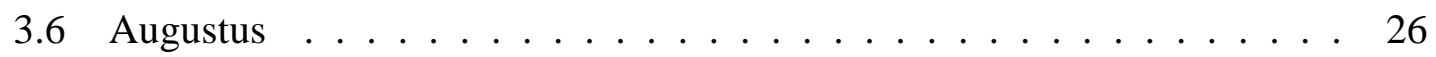

3.7 Tigrscan . . . . . . . . . . . . . . . . . . 27

3.8 GlimmerHMM . . . . . . . . . . . . . . . . . . . 28

3.9 Genemark.hmm . . . . . . . . . . . . . . . . . . 28

4.1 Cadeia de Markov . . . . . . . . . . . . . . . . . . . . 30

4.2 Alinhamento múltiplo . . . . . . . . . . . . . . . . 32

4.3 Exemplo de como estimar uma entrada de $M_{k} \ldots \ldots \ldots$. . . . . . . . . 34

4.4 Cadeia de Markov com ordem $2 \ldots \ldots \ldots$

4.5 Alinhamento e HMM . . . . . . . . . . . . . . . . . . 37

$4.6 \mathrm{GHMM} \ldots \ldots \ldots \ldots \ldots \ldots \ldots$

5.1 Configurando uma GHMM . . . . . . . . . . . . . . . . 46 
5.2 Treinando modelos . . . . . . . . . . . . . . . . . . . 48

5.3 Diagrama de classes do MYOP . . . . . . . . . . . . . . . . . . . 49

5.4 Exemplo de Builder . . . . . . . . . . . . . . . . 53

6.1 Topologia do GlimmerHMM . . . . . . . . . . . . . . . . . . . 57

6.2 Topologia do Phat . . . . . . . . . . . . . . . . 57

6.3 Topologia do Genemark.hmm _. . . . . . . . . . . . . . 57

6.4 Distribuição do comprimento das regiões . . . . . . . . . . . . . . . 59

A.1 Topologia com dois estados . . . . . . . . . . . . . . . . . 78 


\section{Lista de Tabelas}

3.1 Arquitetura dos preditores de genes ............... 23

6.1 Sinais do preditor $\ldots \ldots \ldots \ldots \ldots$

6.2 Tamanho da amostra de cada sinal . . . . . . . . . . . . . 58

6.3 Exatidão do Tigrscan e do GlimmerHMM . . . . . . . . . . . . . . . . . 61

6.4 Exatidão dos modelos $\left(\frac{s_{p}+S_{n}}{2}\right) \ldots \ldots \ldots \ldots \ldots$

6.5 Exatidão dos modelos (sensibilidade) . . . . . . . . . . . . . . 64

6.6 Exatidão dos modelos (especificidade) . . . . . . . . . . . . . 65 


\section{Capítulo 1}

\section{Introdução}

As bases de dados de seqüências de DNA, tal como Genbank [3], têm tido um crescimento exponencial no número de seqüências armazenadas. Considerando o alto custo financeiro de cada experimento biológico, fornecer interpretações biológicas para todas as seqüências é praticamente impossível sem o desenvolvimento de algoritmos eficientes de reconhecimento de padrões [39].

Em particular, podemos observar avanços no desenvolvimento de programas de predição de genes. Esses programas tentam resolver o problema de predição de genes que tem definição diferente dependendo do organismo. Nos organismos procariotos, o problema de predição de genes consiste em encontrar regiões codificadoras que estão representadas de maneira contínua no genoma [53]. Nos organismos eucariotos, este problema consiste em reconhecer precisamente a estrutura éxon-íntron de cada gene [5].

Os programas de predição foram agrupados em diversas gerações [64]. Na primeira geração, eles indicam aproximações das localizações das regiões codificadoras: TestCode [19] e GRAIL [66]. Na segunda geração, eles conseguem localizar os prováveis éxons através da combinação das informações sobre os sinais biológicos e regiões codificadoras: Sorfind [24] e Xpound [61]. Na terceira geração, eles fazem a predição da estrutura completa do gene: GeneLang [13] , FGENEH [56] e GeneId [42]. No entanto, existe a suposição de que a sequiência de entrada tem exatamente um gene. Na próxima geração, cada programa modela as duas fitas de DNA simultaneamente e incluem no modelo a região intergênica, possibilitando encontrar vários genes na mesma seqüência de entrada: Genscan [5], Augustus [59] e Tigrscan [34]. Na geração atual, os preditores de genes utilizam informações sobre similaridade entre os genomas para aumentar a exatidão das predições: TWAIN [35] e Twinscan [29].

Para reconhecer genes por meios biológicos, podemos fazer o sequenciamento de pequenos fragmentos de cDNAs chamados de etiquetas de sequiências expressas (ESTs expressed sequence tags). As seqüências de cDNAs podem ser mapeadas na seqüência 
genômica fornecendo a localização e a estrutura exata de cada gene expresso. Entretanto, os genes raramente expressos serão pobremente representados nas bibliotecas de ESTs [52] e também mais difíceis de serem encontrados. Por outro lado, os programas de predição de genes podem ser utilizados para fornecer evidências de qualquer gene codificador de proteína, inclusive aqueles genes raramente expressos [68]. Além disso, mesmo que seja possível encontrar todos os genes por técnicas biológicas, é importante entender como eles podem ser encontrados usando métodos computacionais, pois, técnicas biológicas são financeiramente caros [68].

Enquanto o número de programas de predição aumenta devido a demanda de técnicas cada vez mais eficientes, a exatidão das predições está longe de ser satisfatória $[68,10]$. Podemos listar cerca de 25 programas com abordagem probabilística [39] dos quais os melhores acertam com precisão somente as estruturas de $20 \%$ dos genes [68]. Além disso, uma comparação recente entre programas contemporâneos mostra que não houve uma mudança significativa na performance nos últimos anos [28].

Podemos reconhecer diversas semelhanças na arquitetura dos programas de predição. Os modelos probabilísticos utilizados são basicamente os mesmos, mas as abordagens de como combinar esses modelos são distintas. Baseado nas características comuns, desenvolvemos um arcabouço para criação de preditores de genes, MYOP (Make Your Own Predictor). Este sistema foi desenvolvido visando possibilitar experimentação, validação e comparação justa das diversas técnicas arquiteturas e modelos probabilísticos utilizados em preditores de genes. Na verdade, o arcabouço não tem a princípio sua aplicação limitada a preditores de genes, mas sim a qualquer domínio de problemas que possa ser modelado com as técnicas probabilísticas aqui implementadas.

\subsection{Objetivo}

O objetivo principal deste trabalho foi o desenvolvimento de um sistema capaz de construir diferentes preditores de genes utilizando os principais modelos probabilísticos aplicados atualmente. Encontramos as seguintes semelhanças em diversos preditores: uso de cadeias ocultas generalizadas de Markov para descrição da arquitetura final do preditor e utilização de variantes de cadeias de Markov para caracterização dos diversos componentes da estrutura dos genes. Porém com exceção do sistema Tigrscan [34], todos tem a estrutura do gene e a definição dos componentes dos genes inseridos diretamente no código fonte, tornando extremamente difícil uma experimentação mais detalhada com cada solução.

Mapeando as semelhanças desenvolvemos um arcabouço para descrição de preditores de genes, o MYOP. Em particular, ele tem as seguintes características: 
- fornece um conjunto de modelos probabilísticos necessários para a construção de preditores de genes;

- tem algoritmos para o treinamento de cada modelo probabilístico;

- gera seqüências por simulação. Esta funcionalidade ajuda a validar a implementação de cada modelo;

- calcula a probabilidade da seqüência dado um modelo;

- salva e carrega os parâmetros de um modelo num arquivo;

- com um modelo de genes treinado, ele fornece predições para cada seqüência de entrada.

\subsection{Organização do trabalho}

No Capítulo 2, apresentamos conceitos fundamentais da Biologia Molecular necessários à compreensão do problema de predição de genes. No Capítulo 3, descrevemos as arquiteturas utilizadas para a descrição de preditores de genes, introduzindo informalmente os modelos probabilísticos utilizados para caracterizar os elementos da arquitetura dos genes. No Capítulo 4, fazemos a descrição formal de cada um destes modelos probabilísticos, bem como do modelo utilizado para descrever a arquitetura dos preditores. O leitor da área de exatas pode optar em ler este capítulo antes do Capítulo 3 para uma maior compreensão do texto. No Capítulo 5, descrevemos em linhas gerais a arquitetura do MYOP bem como a maneira de utilizá-lo para descrever e treinar determinada arquitetura de predição de genes. No Capítulo 6, fazemos um estudo de caso para demonstrar como o sistema pode ser utilizado para implementar e comparar vários modelos de genes diferentes, equivalentes a vários preditores de genes. Em particular implementamos a arquitetura básica dos preditores GeneMark.hmm [33], TigrScan [34], bem como variações destes preditores e dos preditores Phat [9] e GlimmerHMM [34], num total de 96 modelos de genes. Estes modelos foram treinados e testados utilizando dados para Homo sapiens. 


\section{Capítulo 2}

\section{Conceitos biológicos}

Conhecer os conceitos básicos da Biologia Molecular é importante para discutir como um programa de predição de genes funciona. Esse programa tenta representar elementos presentes no dogma central da Biologia Molecular [11], conceito que define o fluxo da informação genética nos seres vivos. Vamos revisar uma parte desse fluxo: a síntese de RNA, e a síntese de proteína. A síntese de RNA e a síntese de proteína dependem de um conjunto de sinais biológicos que indicam a localização de cada região. Na predição de genes, os sinais biológicos e as diferentes regiões do gene são representadas por diferentes modelos probabilísticos. Vamos indicar neste capítulo, baseado no livro Molecular biology of The Cell [1], quais sinais e regiões serão modelados para o problema de predição de genes.

\subsection{A síntese de RNA}

A síntese de RNA a partir de um molde de DNA é chamada de transcrição. Inicialmente, um conjunto de fatores de transcrição deve reconhecer uma seqüência de DNA chamada de promotor que pode estar localizado em regiões distantes do gene, mas em geral está na região 5' do gene. Com a ajuda desses fatores, o complexo enzimático chamado de RNA-polimerase II (pol II) associa-se com o promotor e reconhece o sítio de início de transcrição. A pol II é responsável em abrir a dupla-hélice expondo as bases das duas fitas. Uma das fitas servirá como molde para a síntese de RNA. Cada base do molde faz par com um ribonucleotídeo trifosfatado, e dois desses monômeros são ligados pela pol II para começar uma nova cadeia de RNA. A elongação da cadeia de RNA pode ser resumida pelos seguintes passos: a pol II caminha para a próxima base; a dupla-hélice é desenrolada expondo uma nova região; a polimerase anexa uma próxima base na cadeia de RNA. Esses passos são repetidos várias vezes e termina quando a pol II encontra o sítio de fim de transcrição. Nos organismos eucariotos, o sítio de fim de transcrição é indicado 
pelo sinal de poliadenilação. Finalmente, a polimerase libera a nova molécula de RNA e se solta da molécula de DNA.

Na Figura 2.1, mostramos a pol II fazendo a síntese de uma molécula de mRNA de um organismo eucarioto, o transcrito passa por três transformações, a adição de uma estrutura chamada de 5'CAP, a adição da cauda poli-A e o splicing que remove os íntrons e junta os éxons. A molécula resultante sai do núcleo para possibilitar a tradução do código presente na molécula de mRNA.

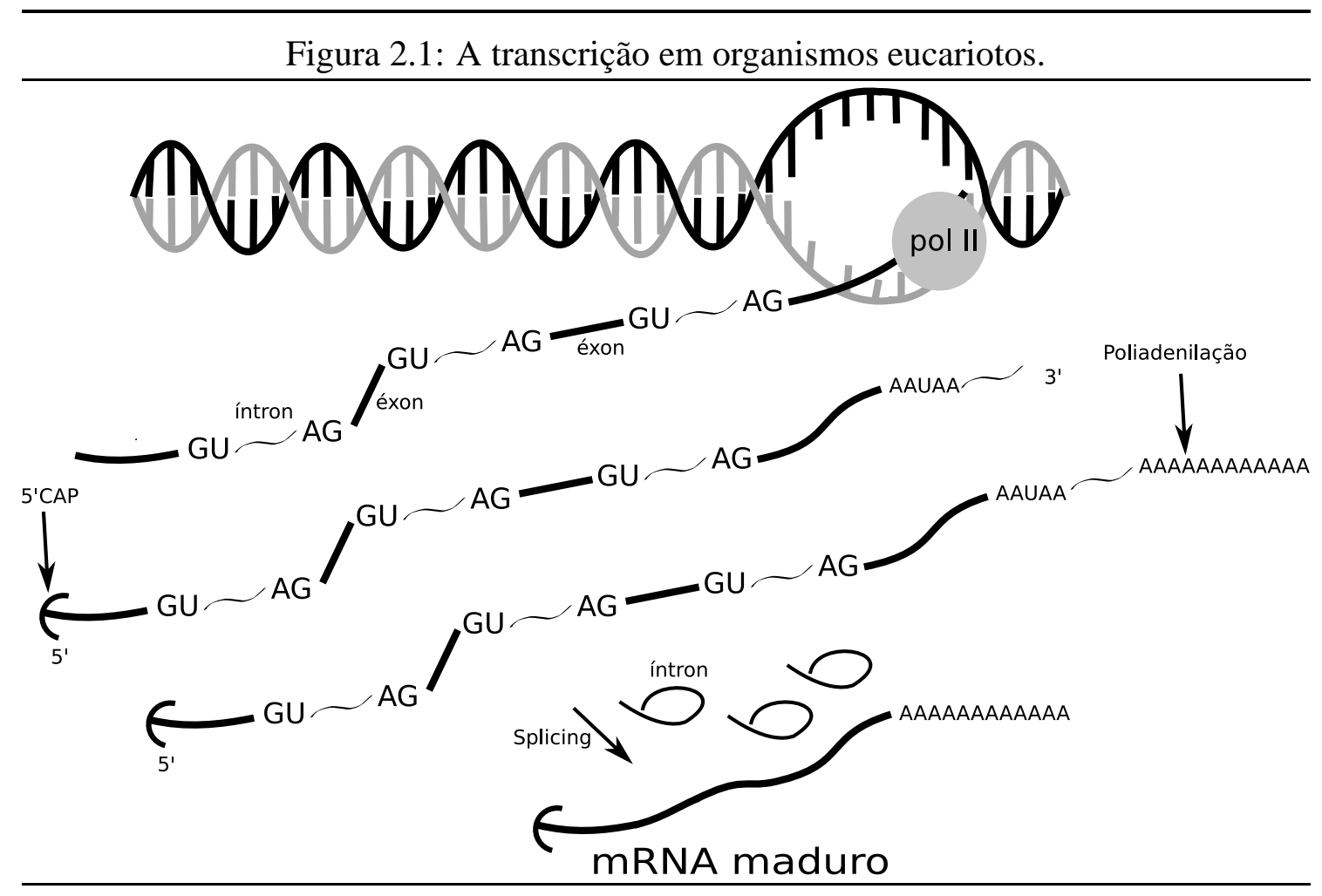

Podemos observar que o promotor, o sítio de início de transcrição, o sítio de fim de transcrição, e o sinal de poliadenilação são os sinais biológicos que são representados por modelos probabilísticos nos programas de predição.

\subsection{Splicing do pre-mRNA mediado pelo spliceossomo}

Nos organismos eucariotos, os íntrons de uma molécula de pre-mRNA podem ser removidos através da ação do complexo spliceossomo que é formado por cinco pequenas partículas de ribonucleoproteína nucleares (snRNPs - small nuclear ribonucleoprotein particles). Na Figura 2.2, apresentamos um diagrama resumindo os passos do splicing. No modelo atual, o primeiro passo é o reconhecimento do sítio 5' de splicing na fronteira entre éxon e íntron chamado de sítio doador. Esse reconhecimento consiste em emparelhar a molécula U1 de snRNA (small nuclear RNA) numa seqüência de aproximadamente 
nove bases que cobrem três bases do éxon e seis do íntron [5]. O segundo passo consiste em reconhecer o ponto de ramificação (branch point) e o sítio aceitador (acceptor site). Esta etapa envolve ligar a molécula U2 e o complexo formado pelos snRNPs U4/U6/U5 na molécula de pre-mRNA formando o spliceossomo.

Após a formação do spliceossomo, reações ocorrem resultando no splicing do RNA. Ocorre a junção dos dois éxons e a remoção do íntron. Os dois éxons unidos soltam-se do spliceossomo enquanto o íntron permanece associado com os snRNPs. Esse complexo intron-snRNPs não é estável e acaba se desmanchando.

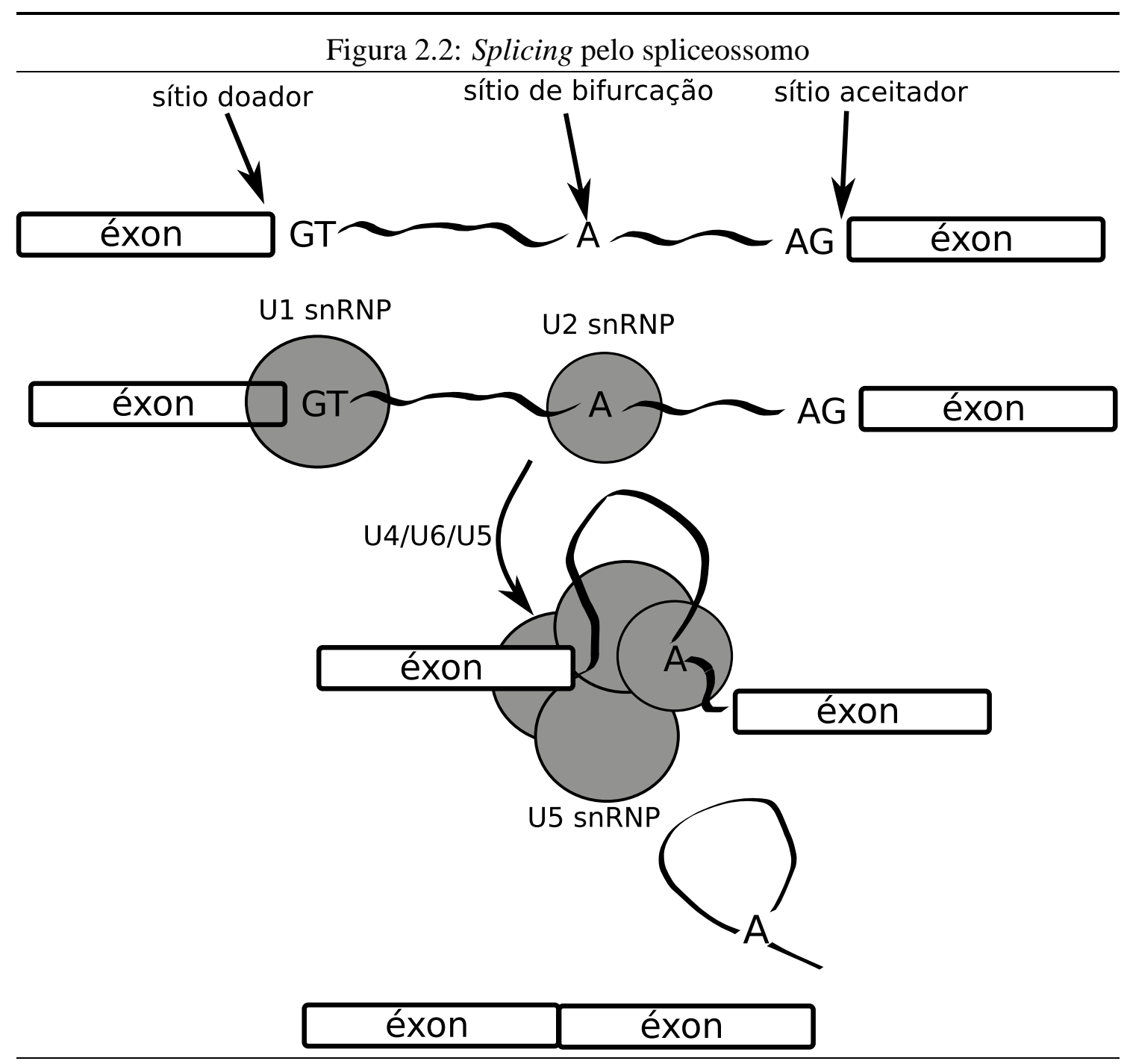

Na predição de genes, os sinais que são reconhecidos pelos snRNAs são também representados pelos modelos probabilísticos. Geralmente, esses sinais biológicos possuem alguma seqüência conservada. No sítio aceitador, existe a seqüência conservada AG na extremidade 3' do íntron. No sítio doador, existe a seqüência GT na extremidade 5' do íntron. 


\subsection{A síntese de proteína}

A síntese de uma proteína, seqüências de aminoácidos ligados por ligações peptídicas, a partir do RNA mensageiro é chamada de tradução. A tradução necessita da ação do RNA transportador (tRNA) que serve como um adaptador que traduz uma sequiência de bases para uma seqüência de aminoácidos [47].

A molécula de tRNA faz par com um códon (sequiência de três bases) encontrado no mRNA, e na outra extremidade ela carrega um único aminoácido. O aminoácido é anexado na extremidade 3' do tRNA, permitindo a ligação entre um aminoácido a um tRNA contendo o anticódon correto (seqüência complementar ao códon). O emparelhamento entre códon e anticódon permite que a proteína seja formada segundo o código dado pelo mRNA.

O códon determina o resíduo de aminoácido específico a ser adicionado na crescente cadeia polipeptídica, já que apenas um dos vários tipos de tRNAs pode emparelhar com cada códon. As bases do RNA podem ser representadas por um alfabeto de quatro letras, o que fornece 64 possíveis seqüências de três bases $\left(4^{3}\right)$, e todas podem ocorrer nas moléculas de mRNA. Três códons (geralmente UAG, UAA, UGA), conhecidos como códons de terminação, não codificam para nenhum aminoácido. Os outros 61 códons devem especificar apenas 20 diferentes aminoácidos, isto é, existe um aminoácido associado a muitos códons. Em outras palavras, o código genético é degenerado.[12].

Iniciando no códon de iniciação, localizado no sítio de início de tradução, a maquinaria da tradução anda no sentido $5^{\prime} \rightarrow 3$ ' sobre uma molécula de mRNA que é lida a cada três nucleotídeos. O fim da tradução é sinalizado pelo códon de terminação que está no sítio de fim de tradução.

Na Figura 2.3, apresentamos a tradução, cada códon na região codificadora da molécula de mRNA é mapeado por uma tRNA que carrega um aminoácido específico. O ribossomo serve para manter as duas moléculas de tRNA na posição correta possibilitando a ligação peptídica.

Como os códons são constituídos de 3 bases, para uma mesma seqüência de RNA podemos utilizar 3 diferentes fases de leitura, cada uma resultando em uma seqüência diferente de aminoácidos. As fases de leitura correspondem às possíveis posições em que começamos a tradução. Considerando a seqüência genômica, existem seis possíveis fases de leitura, uma vez que o DNA se constitui de uma fita dupla e cada uma das fitas pode ser utilizada para a transcrição. A fase de leitura utilizada é determinada pela localização em que o ribossomo é montado sobre a molécula de mRNA e qual das fitas é a codificadora.

Na predição de genes, é importante ter modelos para representar tanto a região codificadora, quanto a região intergênica. Utilizamos, também, um modelo para representar 
Figura 2.3: A maquinaria traduzindo uma seqüência do RNA mensageiro: (a) dois RNA transportadores carregando um aminoácido dentro do ribossomo e fazendo par com os códons específicos. (b) Ocorre a ligação peptídica, (c) O próximo códon vai ser processado pela maquinaria.

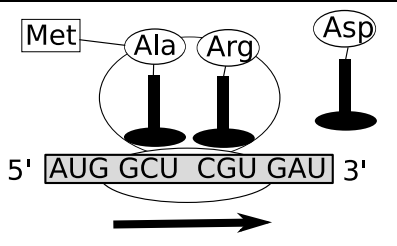

(a) Dois RNA transportadores fazendo par com os códons

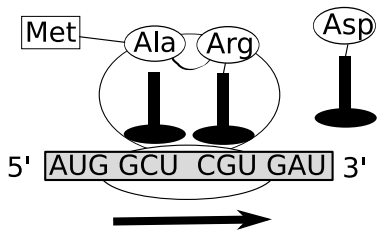

(b) Ligação peptídica

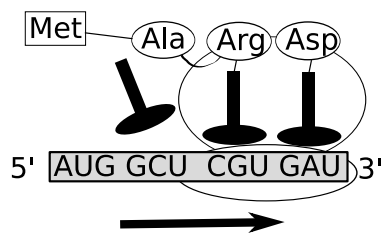

(c) A maquinaria processa o próximo códon

o sítio de início de tradução contendo o códon de iniciação como sequiência conservada e um modelo para o sítio de fim de tradução que tem como sequiências conservadas os códons de terminação e indicam quando a tradução termina.

\subsection{Estruturas dos genes de eucariotos e procariotos}

Os procariotos possuem cromossomos circulares com alta densidade de genes os quais codificam de forma contínua as proteínas. É comum encontrar na mesma molécula de mRNA várias proteínas codificadas em diferentes ORFs. A Figura 2.4 mostra a organização de um RNA mensageiro de organismos procariotos, nesta molécula de mRNA existem três genes codificadores de proteína consecutivos numa organização chamada de operon. O reconhecimento de genes neste caso não pode supor a existência de uma região promotora para cada gene, observamos um único promotor para diferentes genes consecutivos.

Nos organismos eucariotos, é comum encontrar genes grandes (o maior gene humano tem $\approx 2.5 \mathrm{Mbp}[22])$, mas apenas uma pequena parte de cada gene é utilizada para a produção de proteína. Na Figura 2.5, apresentamos a estrutura dos genes de eucariotos. O gene pode apresentar uma estrutura que possui dois tipos de regiões chamados de éxons e íntrons. Podemos listar quatro tipos de éxons: éxon inicial; éxon final; éxon interno; e o éxon único. O primeiro éxon do gene, chamado de éxon inicial, tem uma região não traduzida chamada de 5'UTR (região 5' não traduzida). O último éxon do gene, chamado de éxon final, tem uma região não traduzida chamada de 3'UTR (região 3' não traduzida). O éxon interno aparece entre dois íntrons e pode não existir no gene. Um éxon 
Figura 2.4: O RNA mensageiro de procarioto pode conter várias regiões contínuas que codificam para proteínas diferentes, o grupo de gene consecutivo é denominado de operon.

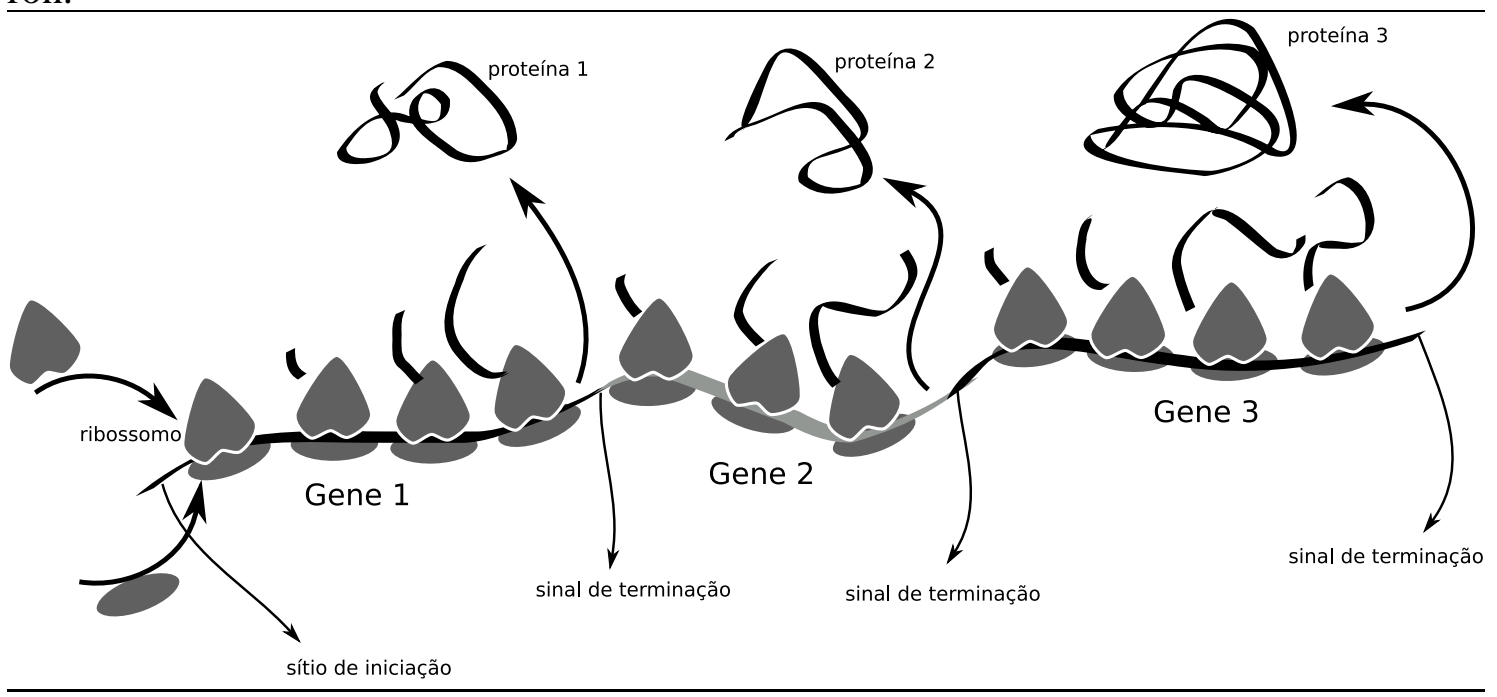

único aparece em genes que não tem íntron. No gene, existe o sinal de poliadenilação que serve para indicar o fim da transcrição e para indicar a localização em que será adicionada a cauda poli-A.

As abordagens de predição de genes utilizam a suposição de que regiões similares podem ter funções similares. Por exemplo, é de esperar que os sinais biológicos tal como sítio doador, sítio aceitador, sinal de início de tradução e sinal de fim de tradução tenham seqüiências que são conservadas devido à ação da seleção natural. Além disso, as regiões codificadoras possuem aspectos diferente em relação a região não-codificadora, já que a pressão de seleção nesses dois tipos de região é diferente. Por exemplo, a terceira posição de cada códon da região codificadora pode variar mais freqüentemente em relação as duas primeiras posições, pois ao variar a terceira posição do códon provavelmente o respectivo aminoácido não muda na proteína codificada. As regiões não codificadoras não estão sujeitas a esse tipo de pressão de seleção, mas elas podem ter outras funções e conseqüentemente uma evolução diferente. 


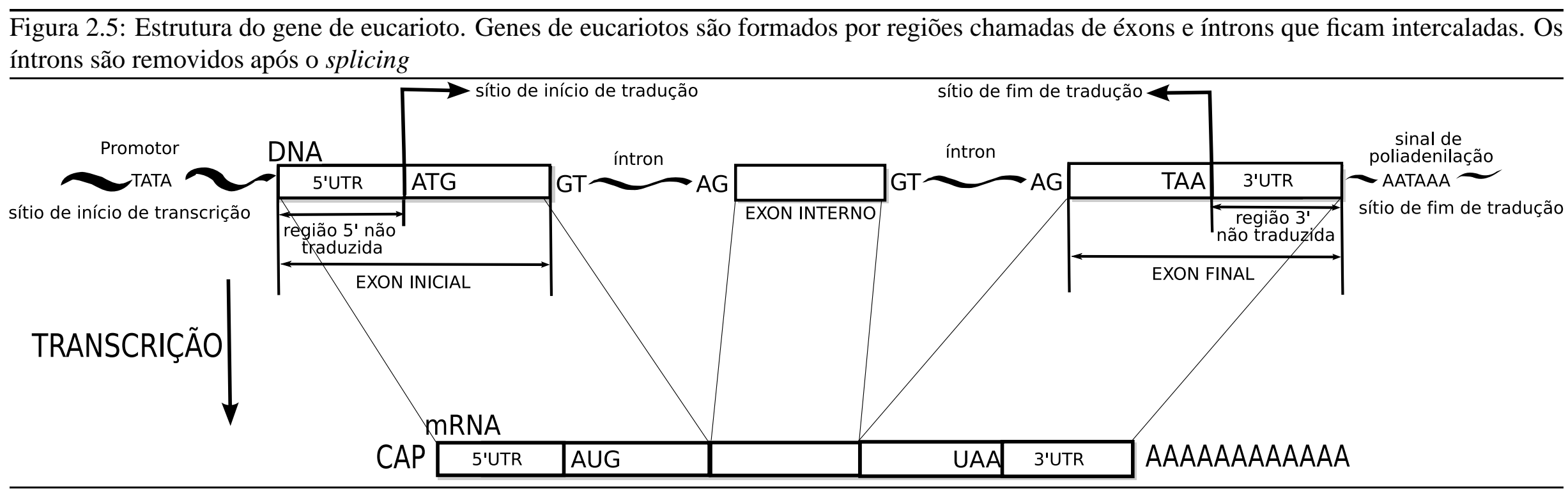
íntrons são removidos após o splicing

sítio de início de transcrição




\section{Capítulo 3}

\section{Abordagens para predição de genes}

Existem basicamente duas abordagens para a predição de genes. A primeira é chamada de abordagem extrínseca e utiliza comparações entre diferentes sequiências. A segunda é chamada de abordagem intrínseca e utiliza aspectos da própria sequiência. Um preditor de genes que utiliza apenas a abordagem intrínseca é chamado de preditor ab initio. Note que essas duas abordagens podem ser combinadas para melhorar a exatidão das predições. Um exemplo é o programa Twinscan [29].

A abordagem intrínseca explora duas linhas de raciocínio [5]. A primeira tenta combinar todas as medidas discriminatórias entre regiões (éxon, íntron, região intergênica) utilizando alguma função, em que cada medida tem um peso estimado ou fixado manualmente. MZEF [70] é um exemplo de programa que utiliza esta abordagem, ele explora uma combinação de medidas para fazer o reconhecimento de éxons utilizando análise de discriminantes. A segunda abordagem é a de modelar exatamente cada passo bioquímico por trás da transcrição e da tradução. Esta abordagem é impraticável, pois não conhecemos precisamente o funcionamento de cada passo da transcrição ou tradução. Utilizamos uma abordagem probabilística que é um intermediário dessas duas idéias e representa cada região do gene por um modelo probabilístico.

Geralmente, programas com abordagem probabilística dividem o problema de predição em três partes: (a) reconhecimento de sinais biológicos usando modelos probabilísticos para a vizinhança de tamanho fixo destes sinais; (b) reconhecimento de regiões de tamanho variável como éxons, íntrons, e regiões intergênicas; (c) uso de algoritmos de otimização, chamados decodificadores ou analisadores, para encontrar a estrutura mais provável do gene. 


\subsection{Informações utilizadas para a predição de genes}

Para fazer o reconhecimento das diferentes regiões do gene utilizamos várias medidas que tentam discriminar as seqüências de diferente famílias. Essas medidas são chamadas de sensores e podem ser classificadas em dois tipos [39]:

- sensores de sinais tentam reconhecer elementos regulatórios do gene usando as estatísticas das posições vizinhas desses elementos.

- sensores de conteúdo servem para classificar uma região com tamanho variável. Um sensor de conteúdo pode ser classificado em intrínseco (aspectos da própria seqüência) ou extrínseco (comparação entre seqüências diferentes).

Não somos capazes de fazer o reconhecimento dos genes apenas usando os sensores. Esses sensores quando utilizados individualmente fornecem um grande número de falsos positivos [60]. A diminuição desses falsos positivos requer a utilização do conhecimento a priori da estrutura do gene codificador de proteína de cada tipo de organismo [32].

\subsubsection{Sensores de sinais}

Um sensor de sinal é uma medida que classifica uma seqüência, geralmente de tamanho fixo, em algum sinal biológico do gene: sítios aceitadores, sítios doadores, regiões promotoras, sítios de início de tradução, sítios de fim de tradução e sinais de poliadenilação. O reconhecimento de sinais biológicos é um passo importante para uma predição precisa de genes. Em particular, o reconhecimento de sítios de splicing é um problema desafiador o qual existem diversas abordagens [31, 44, 6, 23].

O conjunto de sequiências de cada sinal biológico pode ser representado através de um alinhamento múltiplo. Para resumir a informação deste tipo de alinhamento, a abordagem mais simples é através da utilização da sequiência conservada de cada sinal: ATG para o sítio de início de tradução; TAA, TAG, TGA para sítio de fim de tradução; GT para sítio doador; AG para sítio aceitador. Essas seqüências conservadas podem ser utilizadas para facilitar o reconhecimento de sinais biológicos [39], diminuindo o tempo de processamento do algoritmo de predição. Podemos fazer a busca por um tipo de sinal processando apenas as regiões vizinhas da seqüência conservada ao invés da seqüência de entrada inteira.

Uma outra forma de resumir um alinhamento múltiplo é através do uso de modelos probabilísticos. Um modelo amplamente utilizado é a matriz de pesos posicional (WMM - weight matrix model) que define a probabilidade de uma base em uma dada posição do 
sinal [57]. O modelo WMM é de fácil implementação e amplamente utilizado quando o conjunto de treinamento é relativamente pequeno [5].

Entretanto, a limitação do modelo WMM é que ele supõe independência entre posições, não capturando as dependências entre posições adjacentes do sinal. Para representar tais dependências, podemos utilizar o modelo WAM (weigth array method) [69]. Este modelo tem um parâmetro que define o comprimento da memória, $L$, chamada de ordem. A ordem é o número de posições anteriores que cada posição depende. $\mathrm{O}$ valor de $L$ é fixado manualmente, escolhemos aquele que melhor discrimina um falso sinal de um sinal verdadeiro. A WAM pode ser considerada uma generalização do modelo WMM: quando o valor de $L$ é zero temos uma WAM equivalente ao modelo WMM.

Além disso, podemos observar no genoma regiões com dependências complexas entre posições. Nesse caso, um outro sensor de sinal que pode ser aplicado é o maximal dependence decomposition (MDD) [5] introduzido no programa Genscan. Este modelo é uma árvore de decisão que captura as "dependências mais fortes" logo nos primeiros nós da árvore [67]. Ele é capaz de representar não apenas dependências entre bases adjacentes, mas também dependências entre bases não adjacentes [6].

Finalmente, podemos utilizar gramáticas estocásticas inferidas pelo algoritmo Learn acyclic probabilistic finite automaton (LAPFA) [50, 26]. Em particular, os algoritmos de inferência gramatical têm a capacidade de gerar gramáticas equivalentes aos modelos WMM e WAM sem supor a priori o comprimento da memória. O LAPFA pode gerar modelos com memória variável em cada posição [25].

\subsubsection{Reconhecimento de sinais biológicos}

Suponha que desejamos decidir se uma dada seqüência $S$ é um sinal. Para esse problema, podemos utilizar um modelo probabilístico $\mathrm{M}^{+}$representando a distribuição de probabilidade das sequiências de um sinal. Dado este modelo, a probabilidade de $S$ ser gerada é dada por $P\left(S \mid M^{+}\right)$. Da mesma forma, podemos utilizar um modelo $M^{-}$representando seqüências que não são sinais e a probabilidade da seqüência $S$ ser gerada por esse modelo é dada por $P\left(S \mid M^{-}\right)$. Uma forma de decidir se $S$ é um sinal é calculando a relação entre as probabilidades dos dois modelos, $R=\frac{P\left(S \mid M^{+}\right)}{P\left(S \mid M^{-}\right)}$, quanto maior o valor desta medida maior é a chance da seqüência $S$ pertencer à distribuição do modelo $M^{+}$em relação ao modelo $M^{-}$. Os valores de probabilidade obtidos dos modelos em geral são o produto de números entre 0 e 1 . Para evitar perda de precisão devido às limitações na precisão dos números em um computador, o sensor de sinal é construído calculando-se o logaritmo de 
$R$ que é chamado de razão log-odds [16]:

$$
r_{S}=\log \frac{P\left(S \mid M^{+}\right)}{P\left(S \mid M^{-}\right)}
$$

Podemos verificar que a probabilidade a posteriori é dada por $P\left(M^{+} \mid S\right)=\frac{\exp \left(r_{S}\right)}{1+\exp \left(r_{S}\right)}$. Esta função é chamada de função logística. Quanto maior o valor de $r_{S}$, mais próximo de 1 será o valor de $P\left(M^{+} \mid S\right)$; quanto menor o valor de $r_{S}$, mais próximo de 0 será o valor de $P\left(M^{+} \mid S\right)$. Em outras palavras, $r_{S}$ fornece um valor consistente para o escore da sequiência $S$.

\subsubsection{Sensores de conteúdo intrínsecos}

O sensor de conteúdo intrínseco foi originalmente definido para genomas de organismos procariotos [39]. Nesse tipo de genoma, os genes são seqüências contínuas que não apresentam splicing. Desse modo, podemos localizar regiões codificadoras olhando para longas regiões com quadro de leitura aberta (ORF - open reading frames) definidas como uma seqüência contínua de códons que não tem códon de terminação [40].

Nos procariotos, a presença de ORFs sobrepostas é muito comum, o que dificulta a identificação de ORFs codificadoras. Nos organismos eucariotos, o problema de reconhecer regiões codificadoras é mais complicado, porque regiões traduzidas não são representadas de forma contínua no genoma. Assim outros sensores de conteúdo são aplicados para identificar regiões codificadoras [18]: freqüência de hexâmeros; composição de bases; o conteúdo GC; composição de códons; e periodicidade de bases.

A freqüência dos $k$-meros das regiões codificadoras por fase de leitura ${ }^{1}$ tem o mesmo poder discriminatório do que uma cadeia de Markov com periodicidade três [48]. Teoricamente, quanto maior a ordem da cadeia de Markov utilizada, melhor será a representação da região codificadora. Na prática, não somos capazes de inferir os parâmetros de uma cadeia de Markov com ordem muito alta. O número de parâmetros de uma cadeia de Markov cresce exponencialmente com a ordem [71], e o tamanho do conjunto de treinamento pode não ser suficiente. Uma abordagem alternativa que explora ao mesmo tempo as estatísticas de diferentes $k$-meros, em que $k$ é um valor variável, foi introduzida pelo programa Glimmer [53] que utiliza a cadeia interpolada de Markov (IMM - interpolated Markov model). O IMM e a cadeia de Markov com periodicidade três são os principais sensores de conteúdo utilizados pelos preditores atuais, representando diferentes tipos de regiões do gene $[34,58,9,5]$.

\footnotetext{
${ }^{1}$ Para facilitar a notação, definimos a fase de leitura como o valor de $(p-1) \bmod 3$ (resto da divisão de $p-1$ por 3) em que $p, p \geq 1$, é uma posição da seqüência traduzida.
} 


\subsubsection{Reconhecimento de regiões codificadoras}

O reconhecimento de regiões codificadoras consiste em utilizar uma janela deslizante de tamanho fixo. Para cada seqüência $S$ da janela, decidimos se $S$ é codificadora utilizando modelos representando cada um dos três tipos de regiões: a região codificadora; a região não-codificadora; e a região da fita complementar da região codificadora [4]. Para representar de forma realista a região codificadora e a região da fita complementar utilizamos um modelo para cada fase de leitura. Assim, temos 7 modelos, um para cada fase de leitura e um para regiões não codificadoras, a saber:

- $C O D_{k}$ modelo para a região codificadora da fase $k \in\{0,1,2\}$.

- $S H A_{k}$ modelo para a região da fita complementar, denominada de "shadown", da região codificadora da fase $k \in\{0,1,2\}$.

- NON para representar a região não codificadora.

Para decidir qual é o modelo que melhor descreve um trecho $S$ da sequência genômica, podemos utilizar a regra de decisão de Bayes a qual fornece o menor erro teórico [14]. A decisão de Bayes consiste em escolher aquele modelo com a maior probabilidade $a$ posteriori. Utilizamos assim 7 valores, calculados utilizando as fórmulas abaixo:

$$
\begin{aligned}
& P\left(C O D_{k} \mid S\right)=\frac{P\left(S \mid C O D_{k}\right) P\left(C O D_{k}\right)}{P(S)} \\
& P\left(S H A_{k} \mid S\right)=\frac{P\left(S \mid S H A_{k}\right) P\left(S H A_{k}\right)}{P(S)} \\
& P(N O N \mid S)=\frac{P(S \mid N O N) P(N O N)}{P(S)}
\end{aligned}
$$

Em que, $P\left(S \mid C O D_{k}\right)$ é a probabilidade da seqüência ser gerada pelo modelo da região codificadora na fase $k, P(S \mid N O N)$ é a probabilidade da seqüência ser gerada pelo modelo da região não-codificadora, e $P\left(S \mid S H A_{k}\right)$ é a probabilidade da seqüência $S$ ser gerada pelo modelo da região da fita complementar da região codificadora. As probabilidades $P\left(C O D_{k}\right), P\left(S H A_{k}\right)$ e $P(N O N)$ são chamadas de probabilidades a priori as quais fornecem a probabilidade de uma região qualquer ser codificadora em alguma fase ou não codificadora. A probabilidade da sequiência $P(S)$ atua como um fator normalizador e é dada por: 


$$
\begin{array}{r}
P(S)=\sum_{k \in\{0,1,2\}} P\left(S \mid C O D_{k}\right) P\left(C O D_{k}\right)+ \\
\sum_{k \in\{0,1,2\}} P\left(S H A_{k} \mid S\right) P\left(S H A_{k}\right)+P(S \mid N O N) P(N O N)
\end{array}
$$

Geralmente, $N O N$ é uma cadeia homogênea de Markov. $C O D_{k}$ e $S H A_{k}$ podem ser tanto cadeias de Markov com periodicidade três [4], quanto IMM [53].

\subsubsection{Cadeia oculta generalizada de Markov e predição de genes}

A cadeia oculta generalizada de Markov (GHMM - generalized hidden Markov model) é um arcabouço matemático que pode ser utilizado para representar a estrutura do gene. Os programas que o empregam são geralmente aqueles que possuem os melhores resultados em diversas avaliações [48, 43, 7]. Uma GHMM é formada por um conjunto de estados $Q$, uma matriz de transição de estados $T$, e para cada estado está associado um modelo probabilístico representando uma distribuição de emissão.

Uma diferença entre uma GHMM com relação à uma cadeia oculta de Markov (HMM - hidden Markov model) é a possibilidade de modelar explicitamente a duração de cada estado. Ao utilizar uma HMM estamos supondo que cada estado tem uma duração com distribuição geométrica. Contudo, a distribuição de tamanhos de éxons não é uma geométrica ${ }^{2}$. Com GHMMs podemos representar de forma mais realista a distribuição do tamanho de cada região do gene $[5,41]$.

\section{Estados e transições}

Em uma GHMM para predição de genes utilizamos dois tipos de estados: estados que emitem palavras de tamanho fixo, e estados que emitem palavras de tamanho variável. Cada estado deve ter algum significado biológico, bem como cada transição deve ser biologicamente válida.

Um exemplo de um modelo de gene está na Figura 3.1. Esta GHMM tem quatro estados para éxons: E_inic (éxon inicial); E_unico (éxon único); E_inte (éxon interno); e E_final (éxon final). Além disso, temos um estado representando a região intergênica $(\mathrm{N})$, e um estado representando o íntron (Intron). Vamos utilizar retângulos para representar estados que emitem palavras de tamanho fixo, e elipses para representar estados que emitem palavras de tamanho variável. A transição recursiva significa que o estado

\footnotetext{
${ }^{2}$ Como veremos no Capítulo 6, os éxons possuem uma distribuição diferente da distribução geométrica e os íntrons possuem uma distribuição similar a distribuição geométrica em H. sapiens
} 
tem uma distribuição geométrica na duração com média igual ao inverso de um menos a probabilidade desta transição.

Figura 3.1: Exemplo de uma GHMM. Os retângulos são estados que emitem palavras de tamanho fixo, e as elipses são estados que emitem palavras de tamanho variável: E_unico (éxon único); N (região intergênica); E_inic (éxon inicial); Intron (íntron); E_inte (éxon interno).

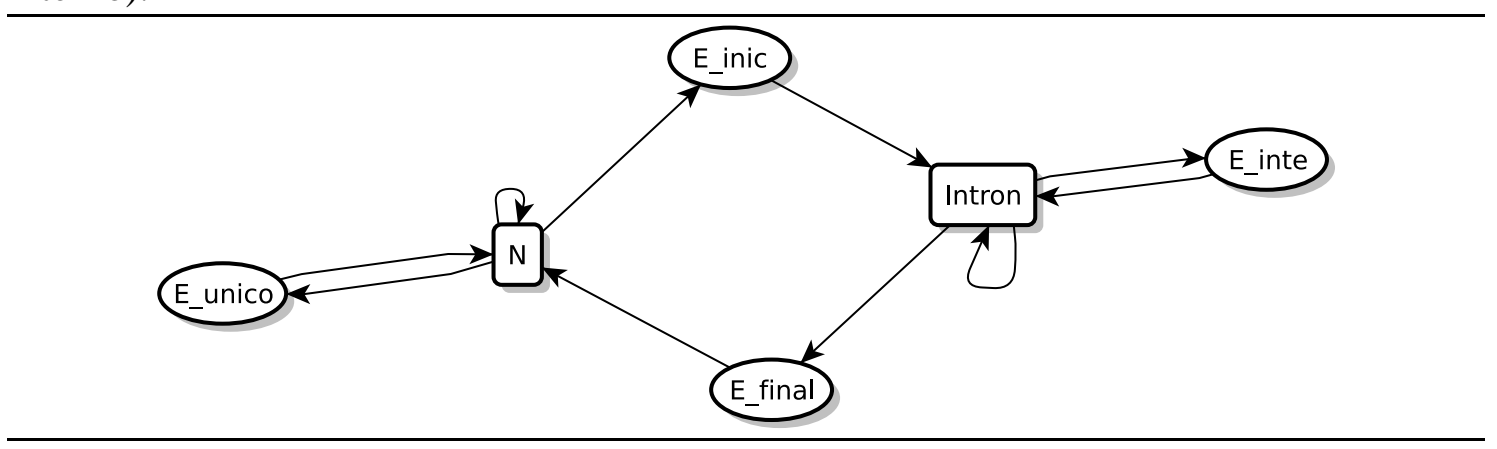

O conjunto de estados e transições forma a topologia da GHMM. Os programas de predição de genes que utilizam GHMMs têm cada um aspectos característicos da topologia do modelo, mas todos utilizam as seguintes idéias: (1) representação das duas fitas do DNA; (2) modelagem das seis fases de leitura; (3) modelagem dos éxons iniciais, éxons internos, éxons finais, éxons únicos, íntrons e região intergênica; (4) as bases dos éxons são todas consideradas codificadoras. Além disso, alguns modelam também as regiões 5' não traduzida e 3' não traduzida.

Um exemplo de uma topologia utilizada na predição de genes está na Figura 3.2. A representação das duas fitas permite que o algoritmo de decodificação processe as duas fitas simultaneamente, além de diminuir o número de falsos positivos. Porém a topologia não permite predições sobrepostas em fitas complementares [4]. O algoritmo de decodificação processa a sequiência de entrada da primeira posição até a última. É por essa razão que um caminho a partir da região intergênica na fita reversa começa com um éxon final. Além disso, para facilitar o rastreamento da fase de leitura, para a fita normal temos 3 estados para modelar éxons iniciais, éxons internos e íntrons (num total de 9 estados da GHMM). Neste mesmo sentido para a fita reversa temos 3 estados para modelar éxons finais, éxons internos e íntrons. Na Figura 3.2, o valor de $k$ nos rótulos E_inic_k, E_inte_k, rE_final_k, e rE_inte_ $k$ indica que o éxon ou íntron termina na fase $k$.

\section{Probabilidade de emissão}

Para calcular a probabilidade de emissão, temos que definir a probabilidade do comprimento, $P(|S|=l)$, para todo $l$, e depois a probabilidade $P\left(S=s_{1} \ldots s_{l}|| S \mid=l\right)$ para toda palavra de tamanho $l$. A probabilidade de emissão é dada por [58]: 
Figura 3.2: Nesta topologia, há a representação das duas fitas: estados que começam com a letra "r" são elementos da fita reversa e estados sem a letra "r" são elementos da fita direta. Encontramos a representação das três fases de leitura de cada uma das fitas: $E \_i n i c \_k$, E_inte_ $k$, rE_final $\_k, r E \_$inte_ $k$, Intro_ $k$ e rIntron $\_k$ representam estados que terminam na fase de leitura $k$. Os éxons dos quatro tipos estão sendo modelados nas duas fitas. As bases dos éxons são todas codificadoras. Finalmente, não há a modelagem das regiões 5' e 3' não traduzidas

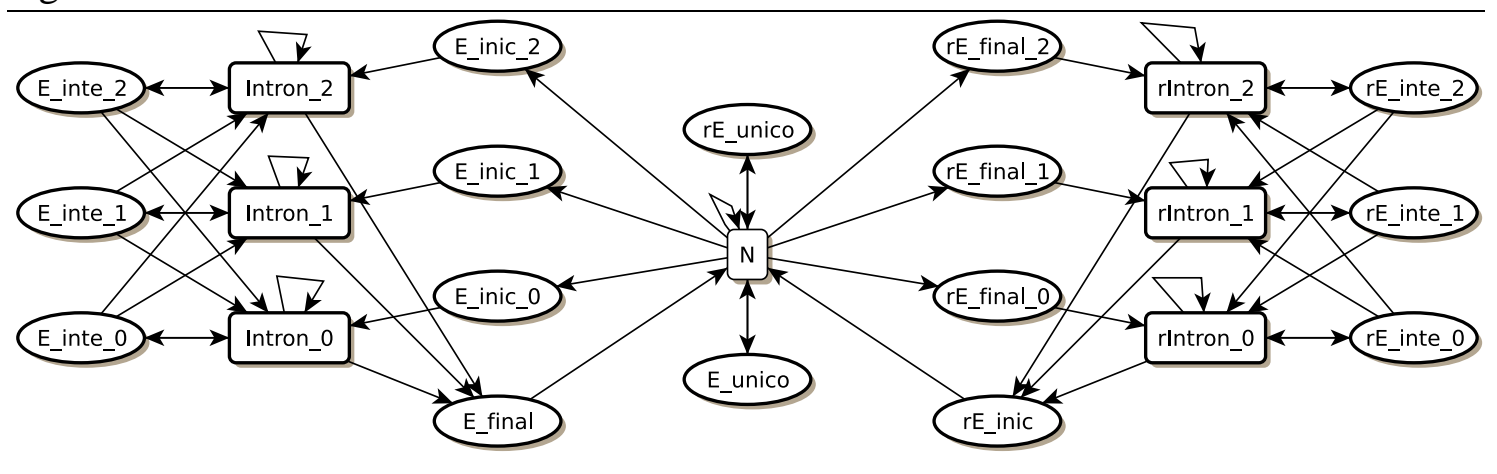

$$
P\left(S=s_{1} \ldots s_{l}\right)=P\left(S=s_{1} \ldots s_{l}|| S \mid=l\right) P(|S|=l)
$$

As distribuições $P(|S|=l)$ e $P\left(S=s_{1} \ldots s_{l}|| S \mid=l\right)$ são definidas para cada estado da GHMM.

\section{Distribuição do tamanho das regiões}

Enquanto os estados que emitem palavras de tamanho fixo possuem distribuição geométrica na duração, a distribuição de duração dos estados que emitem palavras de tamanho variável são fornecidas de maneira explícita [41]. Para estimar a distribuição de probabilidade $d(i)$ do tamanho $i$ de cada tipo de região, é utilizada uma amostra $L=\left\{l_{1}, l_{2}, l_{3}, \ldots, l_{n}\right\}$ de comprimentos. A forma mais simples de estimar a probabilidade de encontrar uma seqüência de tamanho $x$ é através da frequiência relativa do tamanho $x$ na amostra. Contudo, para amostra $L$ pequena, muitos comprimentos não serão observados, resultando numa distribuição de probabilidade estimada que representa muito bem o conjunto de treinamento, mas que tem pouca capacidade de representar amostras fora do conjunto de treinamento. Esse tipo de problema é chamado de overfitting [14], e na tentativa de evitar-lo é necessário fazer a suavização da distribuição observada $[5,58]$, isto é, precisamos ter uma distribuição de probabilidade que aceite também valores não observados. Geralmente, a suavização é baseada no estimador de densidade pela função núcleo (kernel density estimator) [55].

Formalmente, seja $K$ uma função núcleo simétrica em relação ao zero, unimodal, satisfazendo $\int K(x) d x=1$. Seja $h$ um parâmetro de suavização. O estimador da densidade 
é definido por:

$$
\hat{f}_{h}(x)=\frac{1}{n h} \sum_{i=1}^{n} K\left(\frac{x-l_{i}}{h}\right)
$$

O estimador de densidade pela função núcleo distribui o peso $\frac{1}{n}$ para todos os comprimentos observados na área centrado em volta de $x$. A largura da área é o parâmetro de suavização $h$. Se escolhermos um $h$ fixo, podemos ter uma suavização excessiva em algumas regiões, bem como overfitting em outras regiões. Informalmente, quando os valores do comprimento na amostra são muito esparsas, escolhemos uma largura $h$ maior [58], e quando são mais densas escolhemos um valor de $h$ menor. Em particular no preditor de genes AUGUSTUS [58], o valor do parâmetro de suavização é fornecido por:

$$
h(l)=\max \left\{\begin{array}{l}
\frac{0.5}{n^{1 / 5}} l \\
\min \{r \geq 1||\{l, \ldots, l+r-1\} \cap L \mid \geq 8 \text { or }|\{l-r+1, \ldots, l\} \cap L| \geq 8\}
\end{array}\right.
$$

Uma função núcleo, $K$, amplamente utilizada é a função Gaussiana:

$$
K(y)=\frac{1}{\sqrt{2 \pi}} \exp \left(-\frac{y^{2}}{2}\right)
$$

Na predição de genes, estamos interessados em representar comprimentos de regiões utilizando distribuições sobre números inteiros maiores do que 0 . Como $\hat{f}_{h}(i)$ para $i$ inteiro é uma distribuição de probabilidade, ao remover os números não positivos é necessário fazer uma outra normalização [58]:

$$
d(i)=\hat{f}_{h}(i) / \sum_{j=1}^{\infty} \hat{f}_{h}(j) \text { para } i \in\{1,2,3,4,5, \ldots\}
$$

Podemos agora definir o valor de $P(|S|=l)$. Seja $\psi_{1}$ o valor da fase de leitura em que o estado anterior termina, e $\psi_{2}$ a fase de leitura em que o estado atual termina, e seja $k$ um fator normalizador, temos que:

$$
P(|S|=l)=\left\{\begin{array}{l}
d(l) k \text { se }\left(\psi_{1}+l\right) \bmod 3=\psi_{2} \text { e } l \geq 1 \\
0 \text { caso contrário }
\end{array}\right.
$$

O fator $k$ deve ser próximo de 3.0, pois, estamos removendo aproximadamente 1/3 dos elementos da distribuição dada por $d$. Cada fator $k$ pode ser pré-calculando para cada par de fases $\left(\psi_{1}, \psi_{2}\right)$. 


\subsection{Arquitetura dos preditores atuais}

Na Tabela 3.1, apresentamos os modelos probabilísticos utilizados pelos atuais programas de predição. Para fazer o reconhecimento de sinais, os programas desta lista utilizam praticamente os mesmos modelos (exceto o Genie [46] que utiliza redes neurais). Em particular, os modelos WMM e WAM são os mais utilizados como sensores de sinais. Cadeias homogêneas de Markov são utilizadas para representar a região não-codificadora. Tanto a cadeia interpolada de Markov quanto a cadeia de Markov com periodicidade três são utilizadas para representar a região codificadora. A metade dos 14 preditores de genes utilizam GHMM como modelo de gene.

Os decodificadores devem fornecer predições em que cada éxon predito fique consistente com a fase de leitura. Uma forma de rastrear a fase de leitura dos éxons é através da topologia da GHMM. Cada estado da topologia dos preditores atuais está rotulado com a fase de entrada, ou com a fase de saída, ou com ambas. As topologias dos preditores Phat [9] (Figura 3.5), e Augustus [59] (Figura 3.6) têm estados rotulados com a fase de saída: o estado E_inic_ $k$ indica que o éxon inicial terminou na fase $k$. A topologia do Genie supõe a existência de exatamente um gene por seqüência de entrada, ela não modela as duas fitas e a região intergênica, os estados dos éxons iniciais estão rotulados com a fase de saída, os estados dos éxon finais estão rotulados com a fase de entrada, os éxons internos com ambas. As topologias dos preditores Genscan [5] (Figura 3.4), GlimmerHMM [34] (Figura 3.8) e Tigrscan [34] (Figura 3.7) utilizam uma topologia que indica a fase de entrada de cada estado. Finalmente, o Genemark.hmm [33](Figura 3.9) tem estados rotulados tanto com a fase de entrada, quanto com a fase de saída. 
Tabela 3.1: Um resumo das tecnologias utilizadas pelos preditores de genes atuais. 3PMC, cadeia de Markov de periodicidade 3; Otimização, o preditor encontra a combinação de éxons que fornece a maior nota; Método linguístico, uma gramática é utilizada para representar as regiões de cada gene, o problema a ser resolvido é a de encontrar a árvore sintática com o menor custo.

\begin{tabular}{|c|c|c|c|c|}
\hline \multirow{2}{*}{ PREDITOR } & \multirow{2}{*}{ ORGANISMO } & \multicolumn{3}{|c|}{ MODELOS } \\
\hline & & SENSOR DE SINAIS & SENSOR DE CONTEÚDO & ESTRUTURA DO GENE \\
\hline GenMark (1993)[4] & procarioto & - & $\begin{array}{l}\text { 3PMC e cadeia de } \\
\text { Markov homogênea }\end{array}$ & - \\
\hline GenLang (1994) [13] & eucarioto & WAM & $\begin{array}{c}\text { freqüencias de } \\
\text { hexameros }\end{array}$ & Método linguístico \\
\hline Genie (1997) [46] & eucarioto & redes neurais & redes neurais & GHMM (Figura 3.3) \\
\hline Genscan (1997) [5] & eucarioto & WMM, WAM, e MDD & $\begin{array}{l}\text { 3PMC e cadeia de } \\
\text { Markov homogênea }\end{array}$ & GHMM (Figura 3.4 ) \\
\hline HMMgene (1997) [30] & eucarioto & HMM & HMM & $\mathrm{CHMM}^{a}$ \\
\hline Glimmer (1998) [53] & procarioto & - & $\begin{array}{l}\text { IMM e cadeia de } \\
\text { Markov homogênea }\end{array}$ & - \\
\hline GlimmerM (1999)[54] & eucarioto & WAM & IMM & Otimização \\
\hline GeneId (2000)[42] & eucarioto & WMM & cadeia de Markov & Otimização \\
\hline Phat (2001)[9] & eucarioto & cadeia de Markov de & 3PMC & GHMM (Figura 3.5) \\
\hline Augustus (2003) [59] & eucarioto & WMM, WAM, e MDD & $\begin{array}{l}\text { IMM e cadeia de } \\
\text { Markov homogênea }\end{array}$ & GHMM (Figura 3.6) \\
\hline Tigrscan (2004)[34] & eucarioto & WMM, WAM, e MDD & IMM ou 3PMC & GHMM (Figura 3.7) \\
\hline GlimmerHMM (2004)[34] & eucarioto & MDD e IMM & IMM & GHMM (Figura 3.8) \\
\hline Genemark.hmm (2005)[33] & eucarioto & WAM & 3PMC & GHMM (Figura 3.9) \\
\hline Agene (2006)[41] & eucarioto & HMM & HMM & HMM \\
\hline
\end{tabular}

${ }^{a}$ O preditor HMMgene utiliza uma HMM em que cada estado tem um rótulo. Este tipo de HMM foi chamado de "CHMM". O problema a ser resolvido é a de encontrar a rotulação mais provável [30]. 


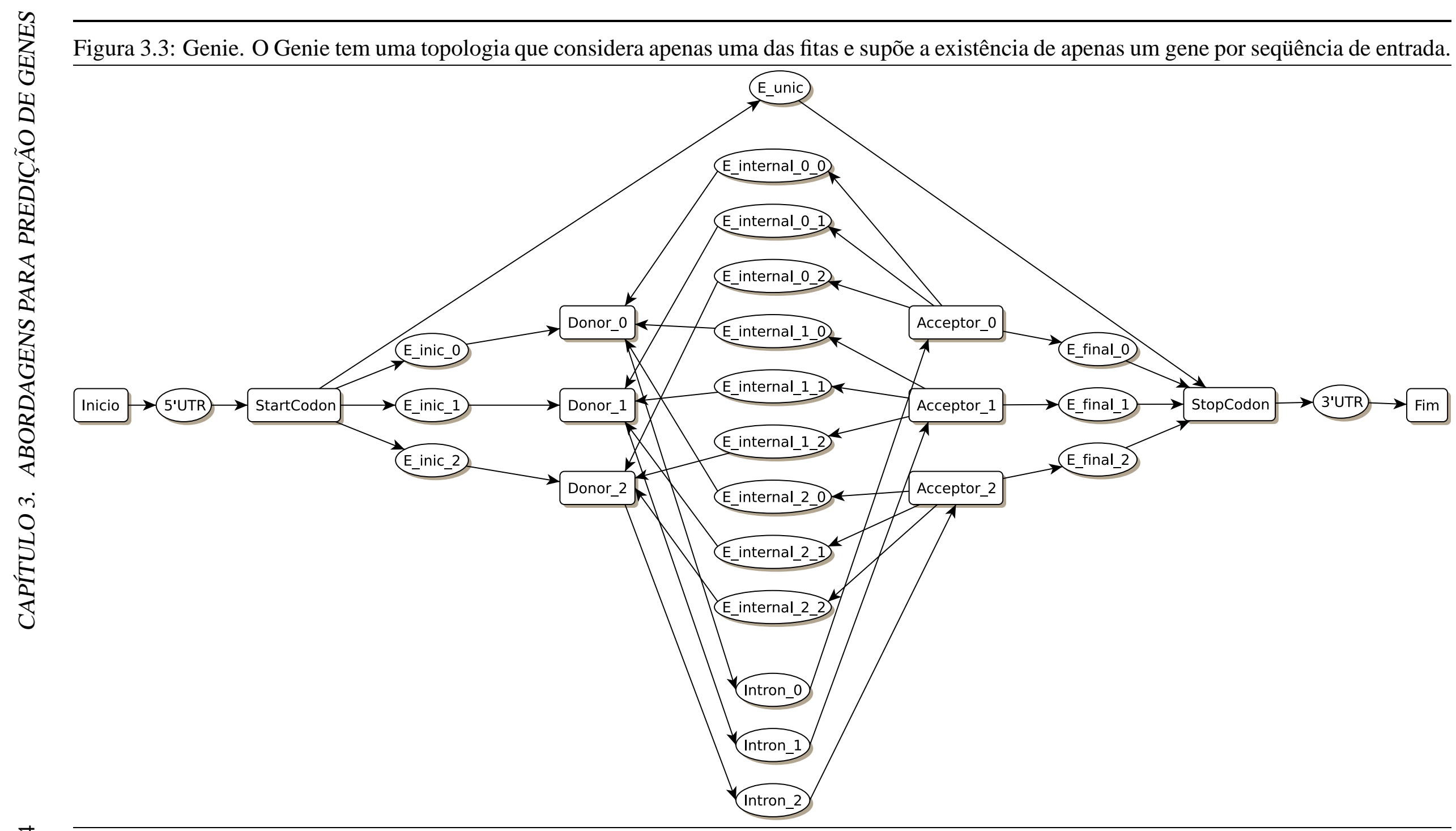


Figura 3.4: Genscan. O Genscan considera as duas fitas simultaneamente. Existe a representação da região promotora, do sítio de poliadenilação, e das regiões 5' e 3' nãocodificadora. Esta topologia permite encontrar diversos genes na mesma sequiência de entrada. Os sensores de sinais fazem parte dos estados representados por elipses.

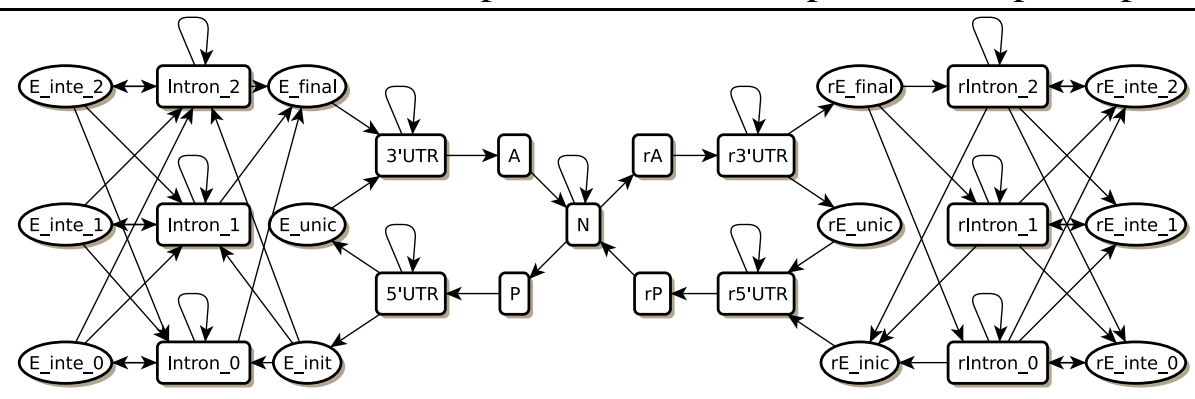

Figura 3.5: Phat. Neste preditor, o modelo de gene foi mantido simples. Segundo o desenvolvedor do Phat [65]: "Due to my lack of experience in genetics I decided to keep the model simple. The gene searching is (almost) entirely nucleotide-composition based, with functional site recognition limited to use of minimal consensi. The three types of state are intergene, exon and intron so there is no modelling of untranslated regions, promoters or poly-A sites. In particular the exon states of this model include only the protein-coding or tranlated section of the initial and final real exons. The UTR sections are considered to be intergenic: the first exon state starts with ATG and the last exon state ends with a stop codon (...)"

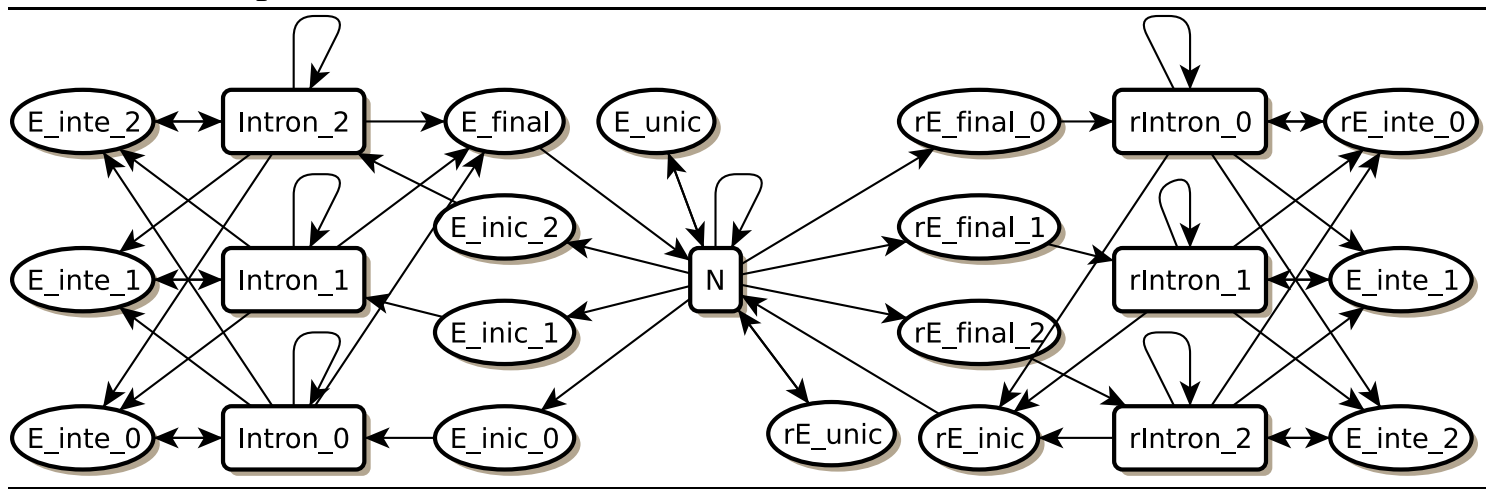


Figura 3.6: Augustus. O preditor de genes Augustus fornece uma modelagem mais detalhada para íntrons.

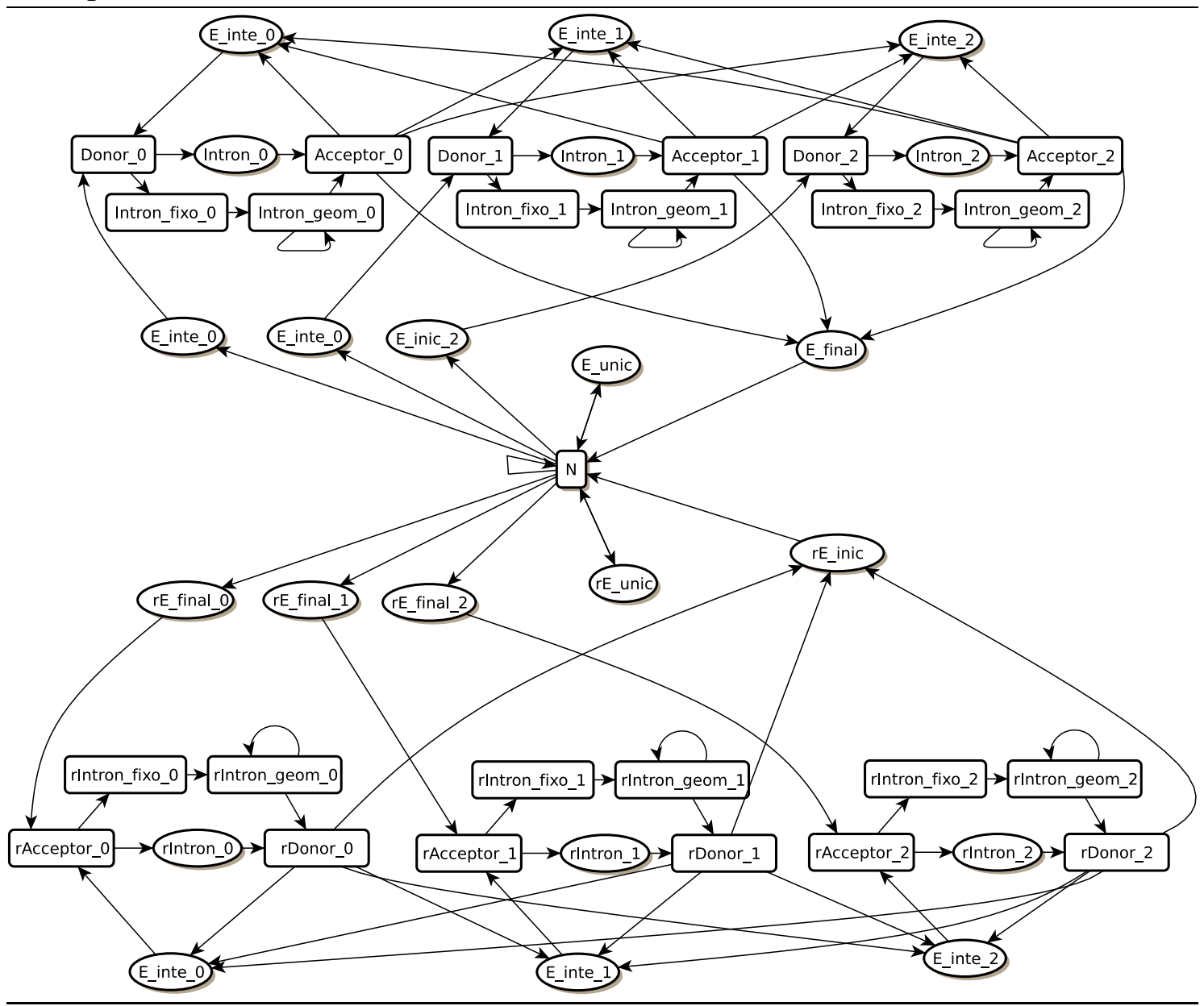


Figura 3.7: Tigrscan. Nesta arquitetura, os sinais também estão representados como sendo um estado que emitem palavras de tamanho fixo. Assim como o Genscan, o Tigrscan tem estados para as regiões 5'UTR, 3'UTR, promotor e sítio de poliadenilação, mas diferente do Genscan tais estados não precisam estar na estrutura do gene predito.

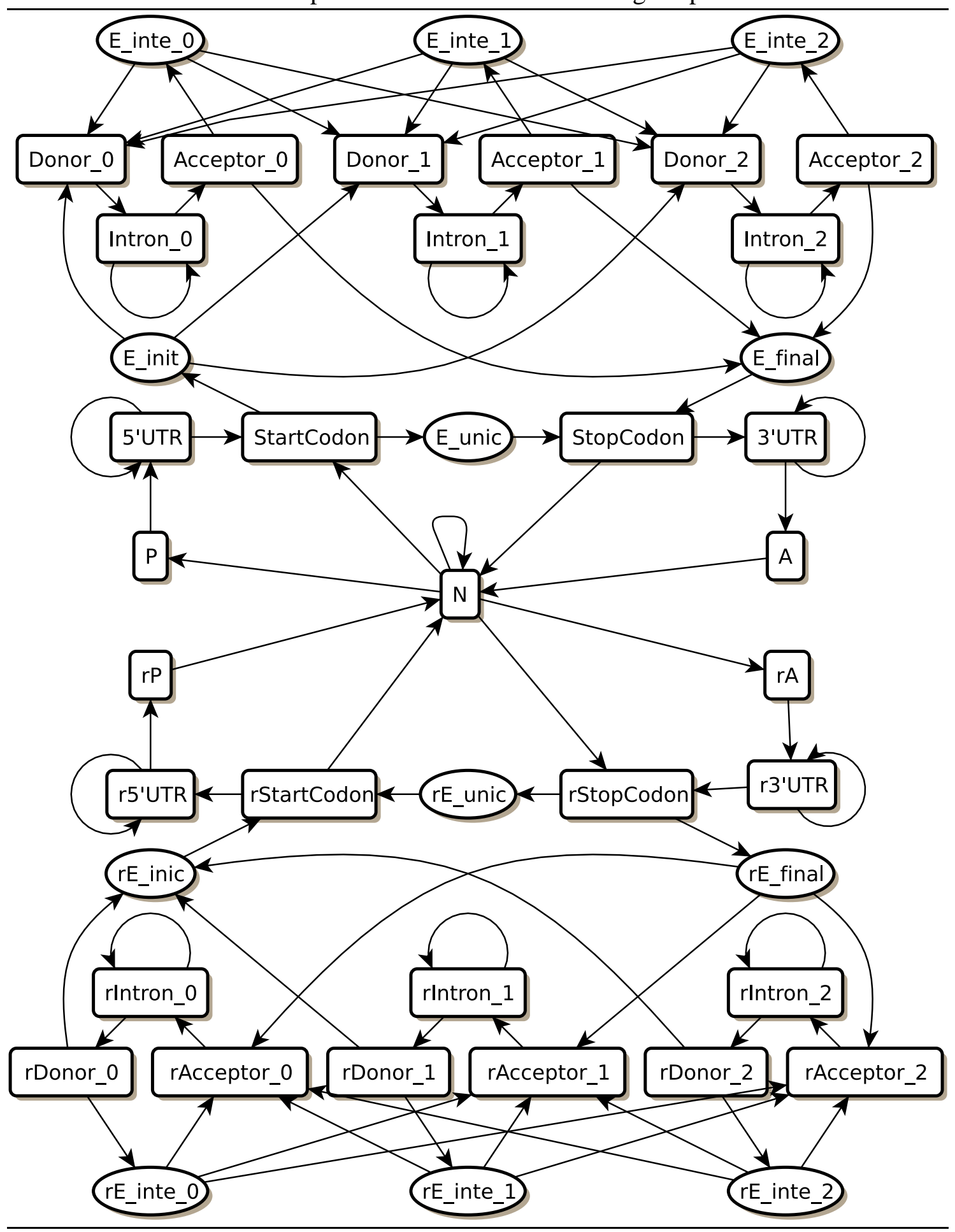


Figura 3.8: GlimmerHMM. Assim como o Phat, o GlimmerHMM não representa as regiões 5'UTR, 3'UTR, promotor e sítio de poliadenilação. Os outros estados são similares aos estados da topologia do Genscan.

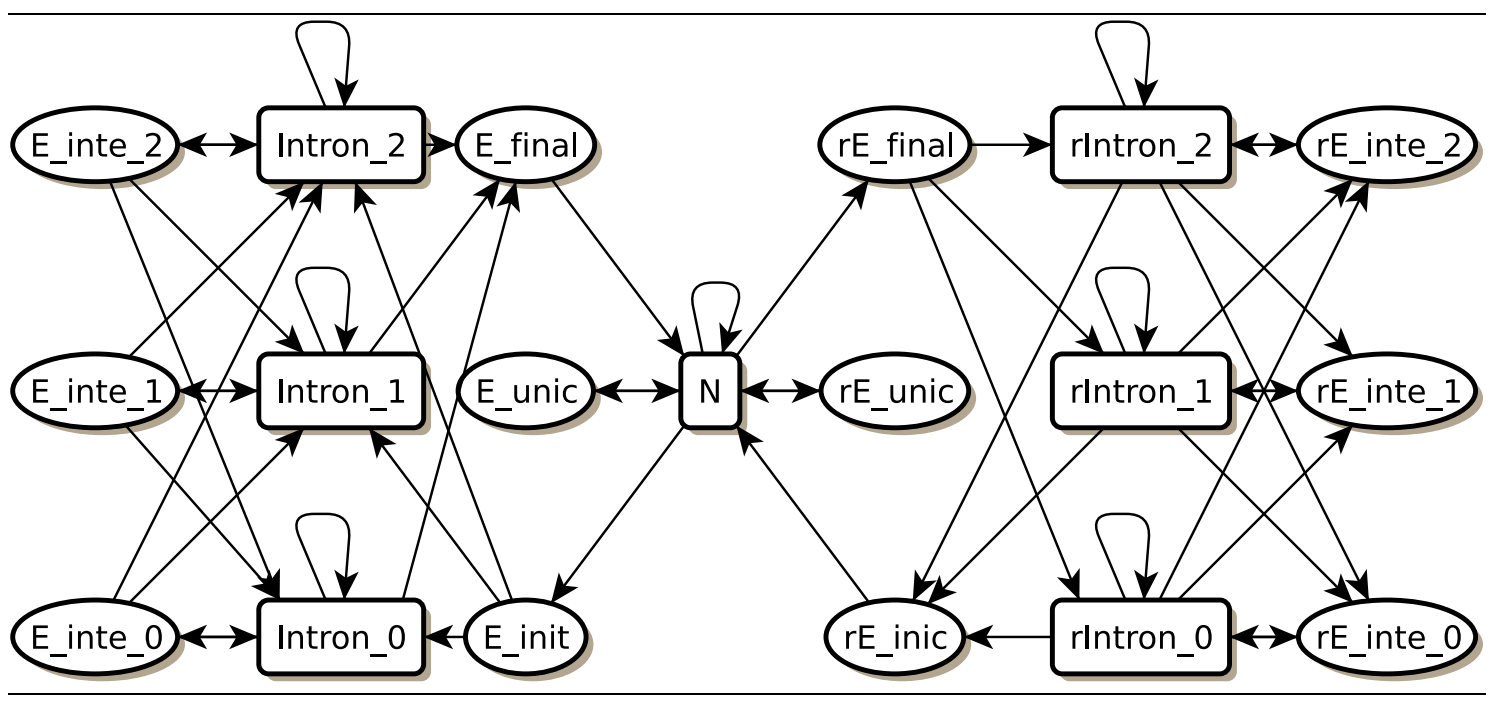

Figura 3.9: Genemark.hmm. Nesta arquitetura, o preditor de genes Genemark.hmm utiliza a topologia da GHMM para rastrear as fases de entrada e saída de cada estado.

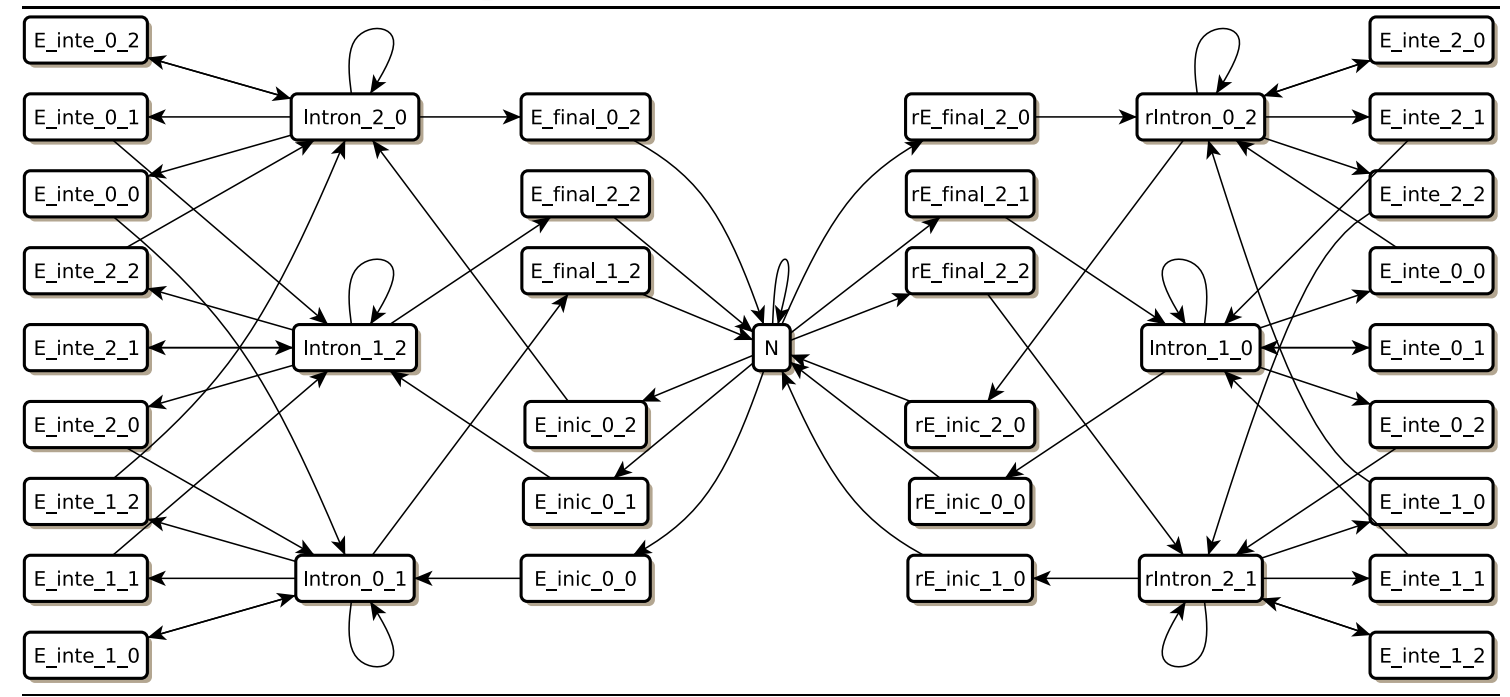




\section{Capítulo 4}

\section{Modelos probabilísticos para a predição de genes}

No Capítulo 3, vimos como um preditor de genes ab initio pode ser construído: precisamos de diferentes modelos representando os sinais biológicos, as regiões do gene, e a estrutura do gene. Neste capítulo, vamos descrever os modelos implementados.

\subsection{Cadeia de Markov}

Na Figura 4.1, apresentamos um grafo em que cada nó representa um estado rotulado com um símbolo do alfabeto $\{A, C, G, T\}$ e cada arco representa uma possível transição. Este modelo serve como um objeto sintático que representa uma distribuição de probabilidade sobre um conjunto de palavras em que todas as palavras tem o mesmo tamanho [63]. Podemos utilizar este grafo para gerar uma palavra utilizando a seguinte simulação. Começamos o processo no estado inicial $A$, e a partir dele um próximo é escolhido usando a distribuição de probabilidade de transição. A medida que caminhamos pelo grafo, uma palavra é formada com a seqüência de estados que foi obtida. A probabilidade de uma palavra neste modelo é dada pelo produto das probabilidades de cada transição do caminho percorrido. Em particular, a seqüência de variáveis aleatórias obtida ao percorrer um caminho neste grafo é uma cadeia de Markov.

Formalmente, uma cadeia de Markov é um processo estocástico construído a partir de um conjunto finito de estados $S$, uma seqüência de variáveis aleatórias $U_{n}$ independentes e uniformemente distribuídas no intervalo $[0,1]$, e uma função de transição $F: S \times[0,1] \rightarrow$ $S$ [17]. O estado inicial, $X_{1}$, pode ser fixado ou escolhido aleatoriamente, o valor do próximo estado é escolhido a partir do valor da variável anterior, isto é, cada variável é 
Figura 4.1: Cadeia de Markov. Cada nó no grafo do lado esquerdo é um estado que foi rotulado por uma letra do alfabeto $\{A, C, G, T\}$ o estado inicial é o estado $A$. Do lado direito há uma possível simulação mostrando a palavra formada e o valor da probabilidade dela ser gerada. A probabilidade da palavra é dada pelo produto das probabilidades de cada transição do caminho. Note que este processo gera distribuições de probabilidade sobre um conjunto de palavras em que as palavras têm todas um mesmo tamanho. Por exemplo, para o conjunto de palavras com tamanho 2, esta cadeia gera a palavra $A A$ ou $A C$ com probabilidade 0.5 , e $A G$ e $A T$ têm probabilidade 0 .
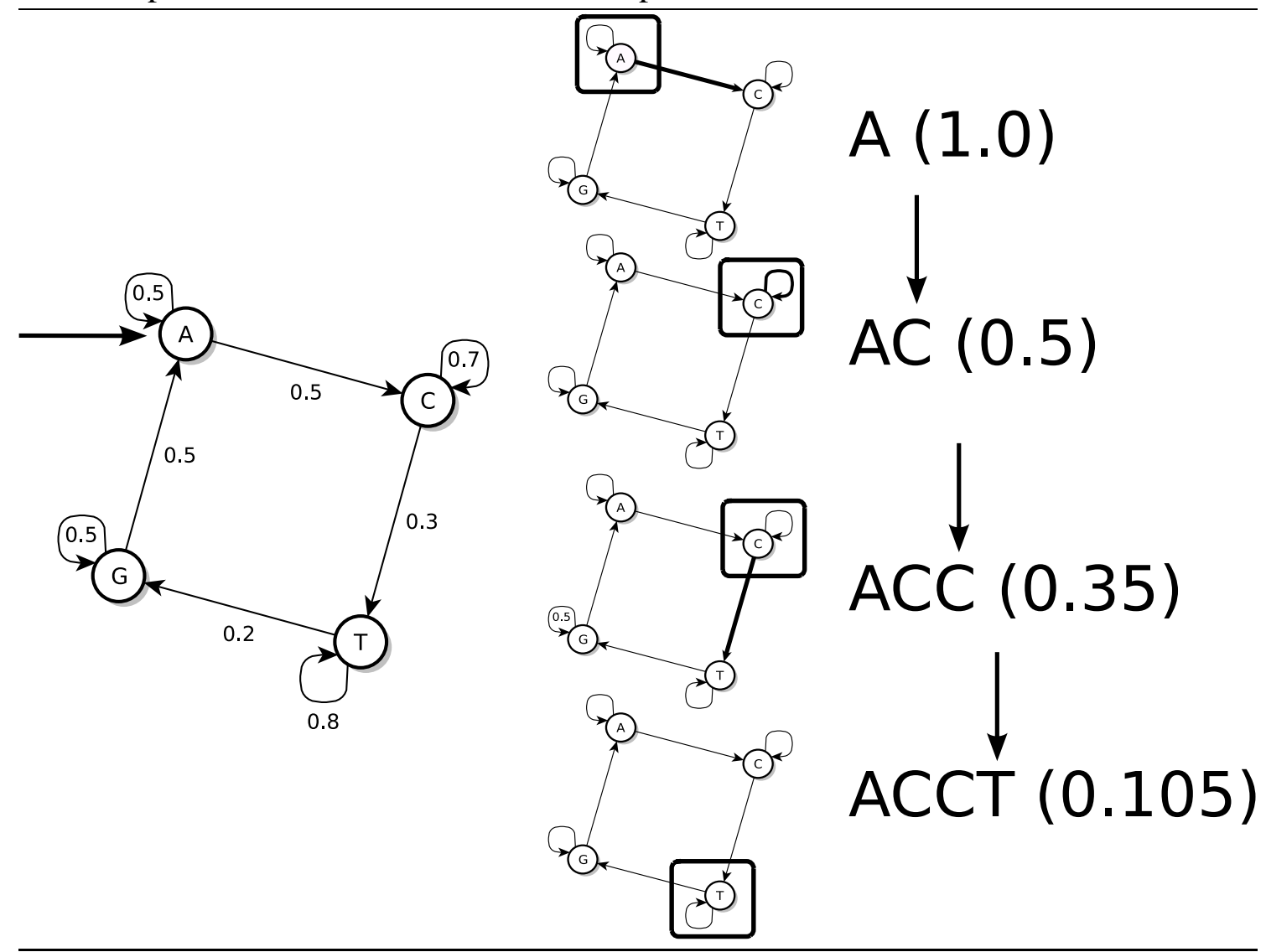
definida por:

$$
X_{n}=F\left(X_{n-1} ; U_{n}\right) \text { para } n>1
$$

Geralmente, utilizamos uma matriz de transição de estados $Q$ para representar uma cadeia de Markov. Cada entrada $Q(x, y)$ é a probabilidade da cadeia estar no estado $y$ no passo $n$ sabendo que estava no estado $x$ no tempo $n-1$ :

Como exemplo, a matriz $Q$ do modelo da Figura 4.1 é dada por

$$
Q=\left[\begin{array}{llll}
Q(A, A) & Q(A, C) & Q(A, G) & Q(A, T) \\
Q(C, A) & Q(C, C) & Q(C, G) & Q(C, T) \\
Q(G, A) & Q(G, C) & Q(G, G) & Q(G, T) \\
Q(T, A) & Q(T, C) & Q(T, G) & Q(T, T)
\end{array}\right]=\left[\begin{array}{llll}
\mathbf{0 . 5} & \mathbf{0 . 5} & 0.0 & 0.0 \\
0.0 & \mathbf{0 . 7} & 0.0 & \mathbf{0 . 3} \\
\mathbf{0 . 5} & 0.0 & \mathbf{0 . 5} & 0.0 \\
0.0 & 0.0 & \mathbf{0 . 2} & \mathbf{0 . 8}
\end{array}\right]
$$

Neste exemplo, podemos observar que a probabilidade do próximo estado no tempo $n+1$ dado o estado atual no tempo $n$ depende apenas do estado atual e não depende do tempo $n$. Neste caso, dizemos que a cadeia de Markov é homogênea. Quando esta probabilidade depende do tempo, então a cadeia de Markov é dita não homogênea. Para cadeias de Markov não homogêneas precisamos de uma função de transição para cada tempo $n$ :

$$
X_{n}=F_{n}\left(X_{n-1} ; U_{n}\right)
$$

Para representar uma cadeia não homogênea de Markov, podemos utilizar uma matriz de transição de estados para cada tempo $n$. Os modelos que serão apresentados nas Seções 4.1.1,4.1.2,4.1.3 são exemplos de cadeias não homogêneas de Markov.

\subsubsection{Weight matrix model}

Na Figura 4.2, apresentamos um alinhamento múltiplo com 12 posições e 10 seqüências do sítio doador. Para resumir este alinhamento, podemos utilizar o modelo weight matrix model (WMM). Ele é utilizado em vários preditores de genes [5, 37, 59] e captura a frequiência de cada letra para cada posição do alinhamento múltiplo [57]. Para cada posição $i$, WMM tem uma distribuição de probabilidade $p_{i}(\sigma)$ de emitir uma letra $\sigma$ do alfabeto $\{A, C, G, T\}$. A distribuição de cada posição é estimada por máxima verossimilhança, isto é, para cada posição $i$ calculamos a freqüência relativa de cada letra $\sigma$. 
Figura 4.2: Alinhamento múltiplo de seqüências do sítio doador. A informação desse tipo de alinhamento deve ser resumida utilizando algum modelo. Em particular, o alinhamento pode ser representado por uma cadeia de Markov não homogênea.

GACAGGTAACTA

AAGAAGTGAGTC

CAAAGGTAAGTG

TAGCGGTGAGGC

CCCTGGTGAGCT

CGCCGGTGAGCT

CACAGGTGAGGG

TGACAGTGAGTA

TCCAGGTAGGTG

GTCAGGTGGGTC

Para o alinhamento da Figura 4.2, podemos calcular os seguintes valores estimados para $p_{i}(\sigma)$ :
$\begin{array}{llllllllllll}1 & 2 & 3 & 4 & 5 & 6 & 7 & 8 & 9 & 10 & 11 & 12\end{array}$
$\begin{array}{llllllllllllll}A & 0.10 & 0.50 & 0.20 & 0.60 & 0.20 & - & - & 0.30 & 0.80 & - & - & 0.20\end{array}$
$\begin{array}{llllllllllllll}C & 0.40 & 0.20 & 0.60 & 0.30 & 0.80 & - & - & 0.70 & - & 0.10 & 0.20 & 0.30\end{array}$
$\begin{array}{llllllllllllll}G & 0.20 & 0.20 & 0.20 & - & - & 1.00 & - & - & 0.20 & 0.90 & 0.20 & 0.30\end{array}$
T $0.30 \quad 0.10 \quad-0.10 \quad-\quad-\quad 1.00 \quad-\quad-\quad-0.600 .20$

O modelo WMM é uma cadeia não homogênea de Markov, em que cada função de transição é dada por:

$$
x=F_{i}(y ; u)=\left\{\begin{array}{lll}
A & \text { se } & u \in\left[0, p_{i}(A)\right) \\
C & \text { se } & u \in\left[p_{i}(A), p_{i}(A)+p_{i}(C)\right) \\
G & \text { se } & u \in\left[p_{i}(A)+p_{i}(C), p_{i}(A)+p_{i}(C)+p_{i}(G)\right) \\
T & \text { se } & u \in\left[p_{i}(A)+p_{i}(C)+p_{i}(G), 1\right]
\end{array}\right.
$$

Cada função de transição nos permite gerar uma palavra por simulação utilizando uma seqüência de variáveis aleatórias com distribuição uniforme. Por exemplo, para cada posição $i$, sorteamos um número aleatório no intervalo $[0,1]$. Se o número sorteado estiver no intervalo $\left[p_{i}(A), p_{i}(A)+p_{i}(C)\right)$, então a letra $C$ é emitida.

Como cada modelo será utilizado para calcular a probabilidade de emissão de um estado da GHMM, precisamos saber como é o cálculo da probabilidade da sequiência dado o modelo, $P(S \mid M O D E L O)$. A WMM gera seqüências de tamanho fixo $n$, e a probabili- 
dade de gerar uma seqüência $S=s_{1} \ldots s_{n}$ usando este modelo é dada pelo produto:

$$
p(S \mid W M M)=\prod_{i=1}^{n} p_{i}\left(s_{i}\right)
$$

\subsubsection{Weight array method}

O modelo weight array method [69] (WAM) é considerado uma generalização do modelo WMM, pois, ele tem a capacidade de capturar dependências entre posições adjacentes da palavra. Este modelo também é uma cadeia não homogênea de Markov. O modelo WAM emite um símbolo $x$ na posição $i$ dado o símbolo $y$ na posição $i-1$ com probabilidade $p_{i}(x \mid y), 1 \leq i \leq n$. A função de transição é dada por:

$$
x=F_{i}(y ; u)=\left\{\begin{array}{lll}
A & \text { se } & u \in\left[0, p_{i}(A \mid y)\right) \\
C & \text { se } & u \in\left[p_{i}(A \mid y), p_{i}(A \mid y)+p_{i}(C \mid y)\right) \\
G & \text { se } & u \in\left[p_{i}(A \mid y)+p_{i}(C \mid y), p_{i}(A \mid y)+p_{i}(C \mid y)+p_{i}(G \mid y)\right) \\
T & \text { se } & u \in\left[p_{i}(A \mid y)+p_{i}(C \mid y)+p_{i}(G \mid y), 1\right]
\end{array}\right.
$$

Para facilitar a notação, se $x$ é uma palavra e $y$ é uma outra palavra, $z=x y$ é a palavra formada pela concatenação de $x \operatorname{com} y$. Vamos chamar de $\epsilon$ o símbolo nulo, símbolo que quando concatenado com uma palavra o resultado é a própria palavra: a palavra $x$ concatenada com $\epsilon$ é igual a palavra $x, \epsilon x=x \epsilon=x$.

O valor estimado para $p_{i}(x \mid y)$ é dado pela razão da quantidade de palavras $y x$ começando na posição $i-1$ com a quantidade de palavra $y$ começando em $i-1: \frac{N_{i-1}(y x)}{N_{i-1}(y)}$. A quantidade de símbolos nulos em qualquer posição é a quantidade de sequiências na amostra. Utilizando como exemplo o alinhamento múltiplo da Figura 4.2, o valor estimado para $p_{2}(A \mid C)$ é dado por $\frac{N_{1}(C A)}{N_{1}(C)}=\frac{2}{4}=0.5$ e o valor estimado de $p_{1}(A \mid \epsilon)$ é dado por $\frac{N_{0}(\epsilon A)}{N_{0}(\epsilon)}=\frac{1}{10}=0.1$.

Da mesma forma que o modelo WMM, o modelo WAM também gera sequiências de tamanho fixo $n$, e a probabilidade de gerar uma seqüência $S=s_{1} \ldots s_{n}$ é dada pelo produto:

$$
P(S \mid W A M)=p_{1}\left(s_{1}\right) \prod_{i=2}^{n} p_{i}\left(s_{i} \mid s_{i-1}\right)
$$

Neste caso, $p_{1}\left(s_{1}\right)=p_{1}\left(s_{1} \mid \epsilon\right)$ é a probabilidade do símbolo $s_{1}$ na posição 1 . 


\subsubsection{Cadeia de Markov com periodicidade três}

Utilizamos uma outra cadeia não homogênea de Markov para representar a região codificadora. Este modelo foi denominado de cadeia de Markov com periodicidade três pelos autores do GeneMark [4]. Para cada fase de leitura, uma matriz de transição de estados $\left(M_{0}, M_{1}\right.$, e $\left.M_{2}\right)$ é utilizada.

Na posição $n$, devemos utilizar a função de transição $F_{k(n)}$, em que $k(n)$ é a fase na posição $n$ :

$$
X_{n}=F_{k(n)}(y ; u)=\left\{\begin{array}{ccl}
A & \text { se } & u \in\left[0, M_{k(n)}(y, A)\right) \\
C & \text { se } & u \in\left[M_{k(n)}(y, A), \sum_{\sigma \in\{A, C\}} M_{k(n)}(y, \sigma)\right) \\
G & \text { se } & u \in\left[\sum_{\sigma \in\{A, C\}} M_{k(n)}(y, \sigma), \sum_{\sigma \in\{A, C, G\}} M_{k(n)}(y, \sigma)\right) \\
T & \text { se } & u \in\left[\sum_{\sigma \in\{A, C, G\}} M_{k(n)}(y, \sigma), 1\right]
\end{array}\right.
$$

Ao utilizar essas três matrizes de transição, o modelo do preditor GeneMark consegue uma representação mais realista da região codificadora, em que cada fase de leitura fica representada.

Os parâmetros deste modelo podem ser estimados por máxima verossimilhança, primeiro todas as sequiências da amostra são concatenadas, depois para cada fase $k$ contamos a quantidade de palavras de tamanho $2, N_{k}(y x)$, e de tamanho $1, N_{k}(y)$, que aparecem na fase $k$. $\mathrm{O}$ valor de cada entrada $M_{k}(y, x)$ é estimado pela razão $\frac{N_{k}(y x)}{N_{k}(y)}$. Um exemplo de como calcular o valor de $M_{1}(G, A)$ está na Figura 4.3, a probabilidade estimada de emitir um $A$ na fase 1 dado que ele já emitiu um $G$ é dada por $\frac{N_{1}(G A)}{N_{1}(G)}=\frac{2}{4}=0.5$.

Figura 4.3: Exemplo de como estimar a entrada $M_{k}(y, x)$. Esta figura mostra como é estimado o valor de $M_{1}(G, A)$, precisamos fazer a contagem da quantidade de palavras $G A$ e $G$ que apareceram na fase 1 . Neste caso, aparecem 2 seqüências GA e 4 sequiências $\mathrm{G}$ na fase 1 . Assim, a probabilidade estimada para $M_{1}(G, A)$ é 0.5

\section{2 AGGTACGGTCGATCGATCGATCGATCG

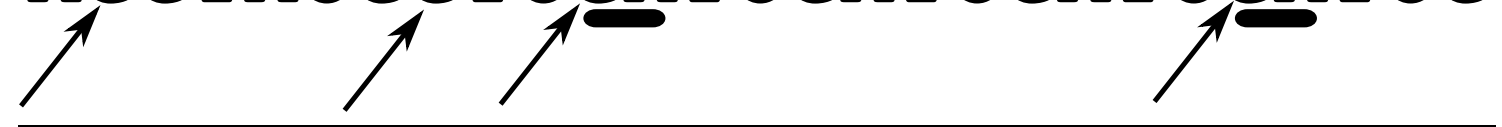

A probabilidade da sequiência ser gerada é fornecida pelo produto:

$$
P(S \mid 3 P M C)=p_{0}\left(s_{1}\right) \prod_{i=2}^{n} M_{k(i)}\left(s_{i-1}, s_{i}\right)
$$

Em que $p_{0}\left(s_{1}\right)$ é a probabilidade de aparecer o símbolo $s_{1}$ na fase 0 . 


\subsubsection{Cadeia de Markov com ordem maior}

Uma suposição feita ao utilizar cadeias de Markov é que a correlação entre duas posições decresce exponencialmente com a distância entre eles [49]. Podemos definir uma distância $L$, chamada de comprimento da memória, tal que a distribuição de probabilidade condicionada a um histórico de comprimento $L$ tem pequenas diferenças com a distribuição de probabilidade condicionada a um histórico de comprimento maior do que $L$ [49]. Se fixamos um valor de $L$, então a cadeia de Markov tem ordem $L$.

Podemos tratar uma cadeia de Markov com ordem $L$ como uma cadeia de Markov com ordem 1 [16, 71]. Para uma cadeia de Markov com ordem $L$, o valor do estado futuro, $X_{k+1}$, depende do histórico conhecido, $X_{k-L+1}, \ldots, X_{k}$. Assim, seja $S_{k}=\left(X_{k-L+1}, \ldots, X_{k}\right)$, então $S_{1}, S_{2}, \ldots$ será uma cadeia de Markov com ordem 1 . Na Figura 4.4, mostramos um exemplo de uma cadeia de Markov com ordem 2 que gera palavras no alfabeto $\Sigma=\{0,1\}$. Neste exemplo, a palavra 00110 foi gerada utilizando a seqüência de estados 00011110 .

Em outras palavras, podemos construir uma cadeia de Markov em que o conjunto de estados é composto por estados rotulados pelas palavras de tamanho $L$ sobre um alfabeto $\Sigma$. Para cada estado, apenas $|\Sigma|$ transições são permitidas, uma transição para cada símbolo do alfabeto. $\mathrm{O}$ estado rotulado pela palavra $s_{1} \ldots s_{L}$ tem apenas as transições para os estados rotulados pelas palavras $s_{2} \ldots s_{L+1}$ para todo $s_{L+1} \in \Sigma$.

Figura 4.4: Cadeia de Markov com ordem 2. No lado esquerdo, um grafo representa uma cadeia de Markov com ordem 2. No lado direito, uma simulação deste modelo gerando a palavra 001100. Omitimos as probabilidades de transição.

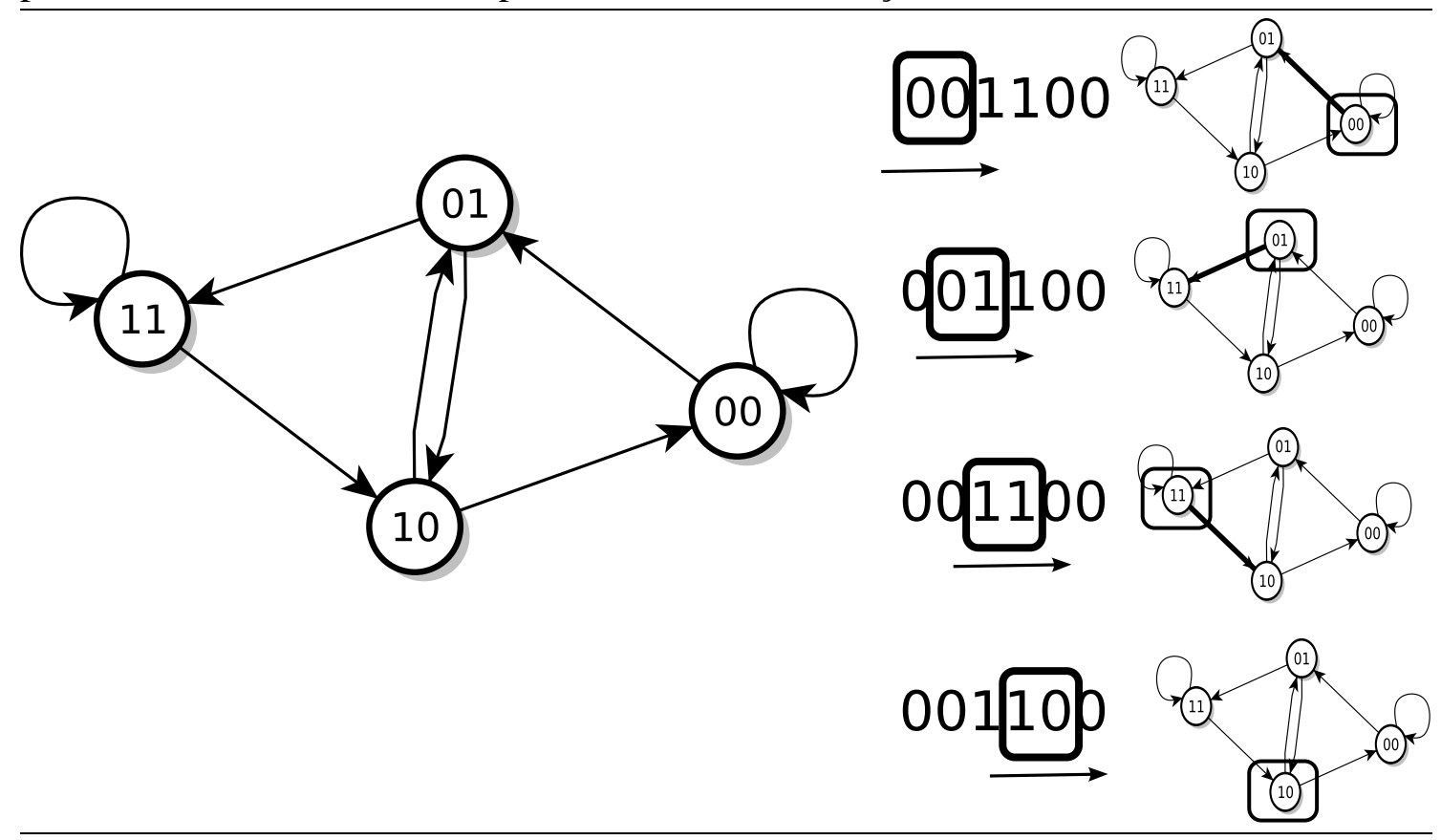




\subsection{Cadeia interpolada de Markov}

Um problema que aparece na prática ao utilizar uma cadeia de Markov com ordem maior é que o número de parâmetros cresce exponencialmente com a ordem. O alfabeto que utilizamos para representar o DNA tem quatro letras, assim a quantidade de probabilidades condicionais é $4^{k+1}$ em que $k$ é a ordem da cadeia de Markov. Assim, para valores grandes de $k$ não há uma amostra suficientemente grande para estimar todas as probabilidades. Se a amostra tem 300 genes com aproximadamente 290000 bases no total, não possuímos uma amostra suficiente para estimar uma cadeia de Markov com ordem 8 que tem 262144 probabilidades condicionais para serem estimadas. Entretanto, foi observado que existem sequiências de tamanho 9 que aparecem em grande quantidade na amostra de regiões codificadoras [53], fornecendo boa estimativa para a probabilidade condicional com histórico de comprimento 8.

A idéia da cadeia interpolada de Markov é o de utilizar a probabilidade condicional com histórico maior quando existem dados suficientes, e a probabilidade condicional com histórico menor quando não existem dados suficientes.

Assim, uma cadeia interpolada de Markov com ordem $k \geq 2$ é uma cadeia de Markov com ordem $k$, em que a probabilidade de observar um símbolo que forma com o histórico uma palavra rara é estimado como uma cadeia de Markov com ordem menor [59].

Para estimar cada probabilidade condicional $P\left(X_{i}=x_{i} \mid X_{i-k}=x_{i-k}, \ldots, X_{i-1}=\right.$ $\left.x_{i-1}\right)$, contamos a freqüência de todas as palavras de tamanho $1,2, \ldots, k+1$. Se o número da palavra $S=x_{i-k} \ldots x_{i}$ for maior do que 400 , então o valor estimado para a probabilidade condicional é dada pela razão da quantidade de $x_{i-k} \ldots x_{i}$ pela quantidade de palavras $x_{i-k} \ldots x_{i-1}$. Se a quantidade da palavra $S$ for menor do que 400 , então o valor estimado para a probabilidade condicional é dada pela razão da quantidade de $x_{i-k-1} \ldots x_{i}$, pela quantidade de $x_{i-k+1} \ldots x_{i-1}$ :

$$
\begin{cases}\frac{N\left(x_{i-k} \ldots x_{i}\right)}{N\left(x_{i-k} \ldots x_{i-1}\right)} & \text { se } N\left(x_{i-k}, \ldots, x_{i-1}\right) \geq 400 \\ \frac{N\left(x_{i-k-1} \ldots x_{i}\right)}{N\left(x_{i-k+1} \ldots x_{i-1}\right)} & \text { caso contrário }\end{cases}
$$

Em que $N(S)$ é a quantidade de palavras $S$ que aparece na amostra. O valor 400 foi escolhido empiricamente [53].

\subsection{Cadeia oculta de Markov}

Uma cadeia oculta de Markov (HMM - hidden Markov model) é construída a partir de uma cadeia de Markov em que cada estado está associado com uma distribuição de pro- 
babilidade de emissão sobre um conjunto de símbolos. Note que a cadeia de Markov não é observada diretamente, mas indiretamente através da emissão.

Podemos utilizar uma cadeia oculta de Markov para representar um alinhamento múltiplo. Na Figura 4.5, uma cadeia oculta de Markov está representando o alinhamento múltiplo de sequiências do sítio doador. Um estado está associado com cada posição do alinhamento, e a probabilidade de emissão é estimada utilizando a frequiência relativa do símbolo na respectiva posição. Como não observamos nenhuma inserção ou deleção neste alinhamento, esta cadeia oculta de Markov é equivalente a uma WMM. No caso em que existem a remoção e inserção de símbolos podemos utilizar uma variação deste modelo chamada de profile-HMM [30] que tem estados especiais representando essas duas ações.

$\overline{\text { Figura 4.5: Alinhamento e HMM. O alinhamento de sinais do sítio doador está represen- }}$ tado por uma cadeia oculta de Markov. Um estado está associado com cada posição deste alinhamento. Cada estado pode emitir um símbolo com a distribuição de probabilidade de emissão estimada com a freqüência relativa de cada símbolo em cada posição.

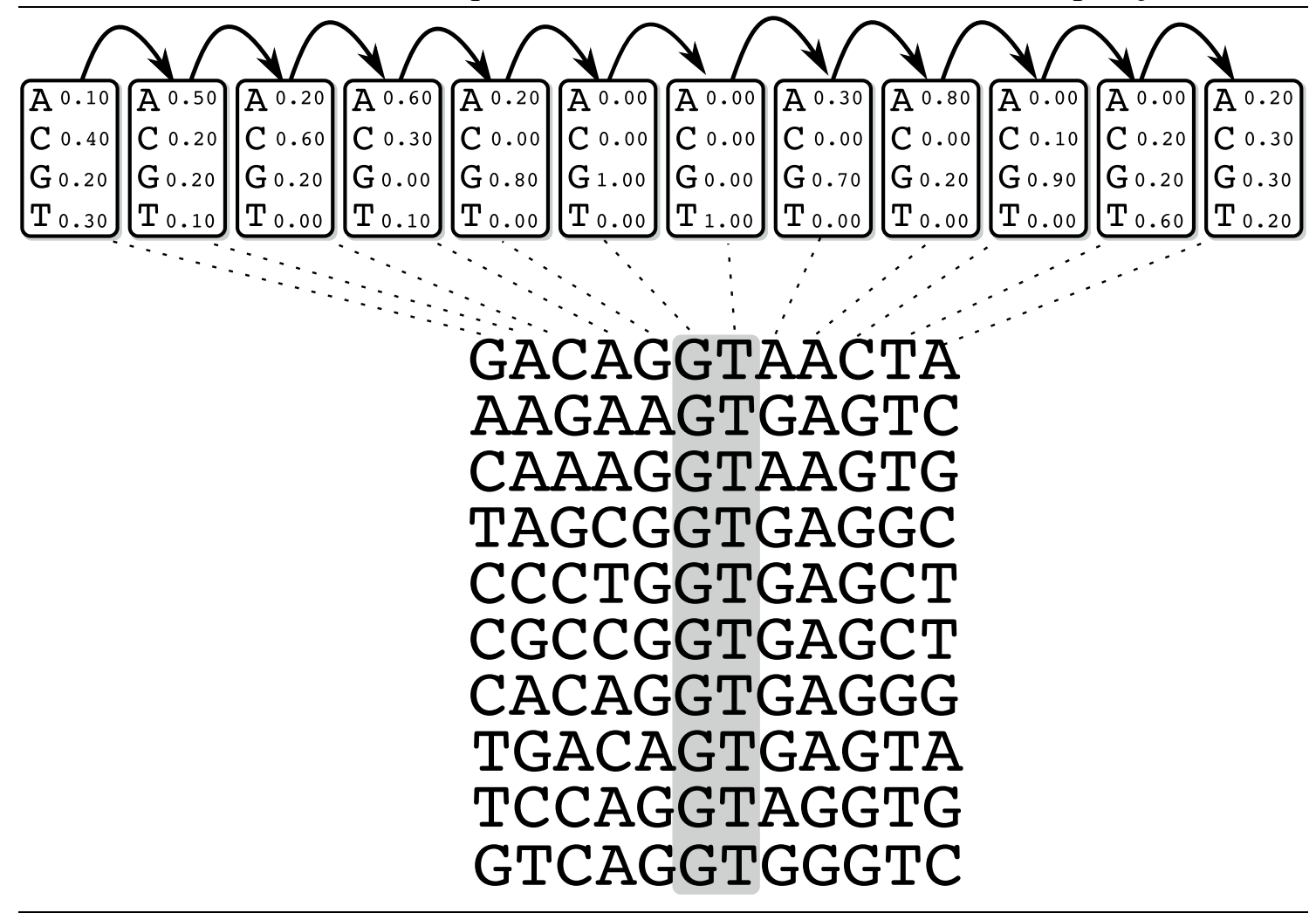

De forma mais formal, a cadeia oculta de Markov [16, 30, 45] é formada por um par de processos estocásticos [71]:

$$
\left(S_{1}, X_{1}\right),\left(S_{2}, X_{2}\right),\left(S_{3}, X_{3}\right), \cdots
$$

Enquanto o processo $X_{1}, X_{2}, X_{3}, \cdots$ é uma cadeia homogênea de Markov com matriz de transição $T$, o processo $S_{1}, S_{2}, S_{3}, \cdots$ é uma seqüência de variáveis aleatórias em que 
cada $S_{i}$ recebe valores de um alfabeto finito $\Sigma$. Esses dois mecanismos probabilísticos discretos estão relacionados por um mapeamento $S_{t}=e\left(X_{t}\right)$. Como $e$ pode ter o mesmo valor em estados diferentes, o processo oculto $\left\{X_{t}\right\}$ é observado de forma indireta através do processo $\left\{S_{t}\right\}[21]$.

Em outras palavras, a cadeia oculta pode ser caracterizada por uma 5-tupla [63] HMM = $(Q, \Sigma, I, T, E)$,

- $Q=\{1, \cdots, m\}$ é o conjunto finito de $m$ estados

- $\Sigma$ é o conjunto finito de símbolos.

- $T: Q \times Q \rightarrow R^{+}$é a função de probabilidade de transição de estado.

- $I: Q \rightarrow R^{+}$é a função de probabilidade inicial de estado.

- $E: Q \times \Sigma \rightarrow R^{+}$é a função de probabilidade de emissão de símbolos de um estado. Esta função fornece o valor da probabilidade de observar $\sigma \in \Sigma$ no estado $q \in Q, P\left(S_{t}=\sigma \mid X_{t}=q\right)$.

Cada função deve descrever uma distribuição de probabilidade, assim elas satisfazem as seguintes restrições:

$$
\begin{gathered}
\Sigma_{q \in Q} I(q)=1 \\
\forall q \in Q, \Sigma_{q^{\prime} \in Q} T\left(q, q^{\prime}\right)=1 \\
\forall q \in Q, \Sigma_{\sigma \in \Sigma} E(q, \sigma)=1
\end{gathered}
$$

\subsubsection{Cálculo da probabilidade da seqüência dado o modelo}

Para calcular a probabilidade da seqüência dado o modelo, podemos utilizar o algoritmo FORWARD que utiliza a probabilidade $\alpha_{t}(i)$ de gerar a seqüência $s_{1} \cdots s_{t}$ e parar no estado $i$ no tempo $t$ :

$$
\alpha_{t}(i)=P\left(S_{1}=s_{1}, \cdots, s_{t}=s_{t}, X_{t}=i\right)
$$

O algoritmo FORWARD recebe uma palavra $S$, e os parâmetros da cadeia oculta de Markov, $H$, e devolve a probabilidade $P(S \mid H M M)$. Este algoritmo calcula o valor de $\alpha_{t}(i)$ utilizando programação dinâmica, isto é, ele utiliza uma tabela para armazenar valores calculados e que podem ser utilizados para calcular novos valores. A inicialização desta tabela está nas linhas 1-2. A probabilidade $\alpha_{1}(i)$ de gerar a seqüência $s_{1}$ e parar 
no estado $i$ é dada pela probabilidade de iniciar o processo no estado $i$ e de emitir o símbolo $s_{1}$ no estado $i$. Após a inicialização, o algoritmo calcula a probabilidade $\alpha_{t+1}(j)$, esta probabilidade é igual a probabilidade de gerar a seqüência $s_{1} \ldots s_{t}$ e parar no estado $j$ $\left(\sum_{i=1}^{m} \alpha_{t}(i) T(i, j)\right)$ e emitir o símbolo $s_{t+1}$ no tempo $t+1$. Finalmente, a probabilidade $P(S \mid H M M)$ é a soma de todas as probabilidades $\alpha_{n}(i)$ para todo o estado $i$. Este algoritmo tem complexidade $O\left(m^{2} n\right)$ em que $n$ é o tamanho da sequiência e $m$ é o número de estados.

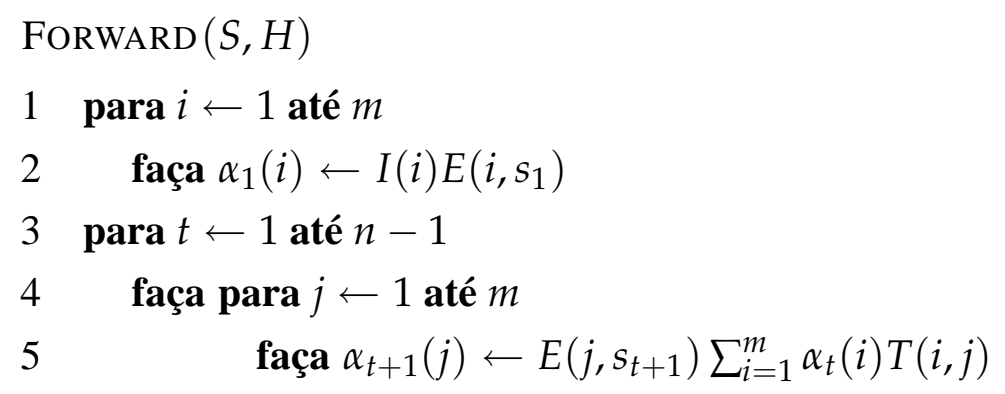

6 devolva $\sum_{i=1}^{m} \alpha_{n}(i)$

\subsubsection{Algoritmo de Viterbi}

Um outro problema que podemos resolver é a de encontrar o caminho mais provável dada a seqüência observada $S$. Este caminho pode ser encontrado utilizando o algoritmo de Viterbi [45], que utiliza programação dinâmica procurando a cada passo o estado anterior mais provável.

O algoritmo HMM_VITERBI recebe uma seqüência $S$ e os parâmetros, $H$, da cadeia oculta de Markov. Ele utiliza a variável de Viterbi, $v_{t}(j)$, que é a probabilidade do caminho único mais provável no tempo $t$ e que termina no estado $j$ com a sequiência observada $s_{1} \ldots s_{t}$. A inicialização da variável de Viterbi está nas linhas 1-2, a probabilidade do melhor caminho para a sequiência de tamanho 1, terminando no estado $i$ é simplesmente a probabilidade de começar no estado $i$ e emitir o símbolo $s_{1}$. Após a inicialização, o algoritmo utiliza valores calculados da variável de Viterbi para calcular o valor de $v_{t}(j)$, procurando pelo estado anterior que fornece o valor máximo de $v_{t}(j)$, este estado é armazenado no vetor $p t r$. Finalmente, a probabilidade do caminho mais provável é o valor máximo de $v_{n}(j)$ para $1 \leq j \leq m$. O algoritmo também precisa reconstruir o caminho ótimo usando a matriz ptr, esta reconstrução está nas linhas 8-10. Este algoritmo tem complexidade $O\left(m^{2} n\right)$, em que $m$ é o número de estados e $n$ é o tamanho da seqüência de entrada. 


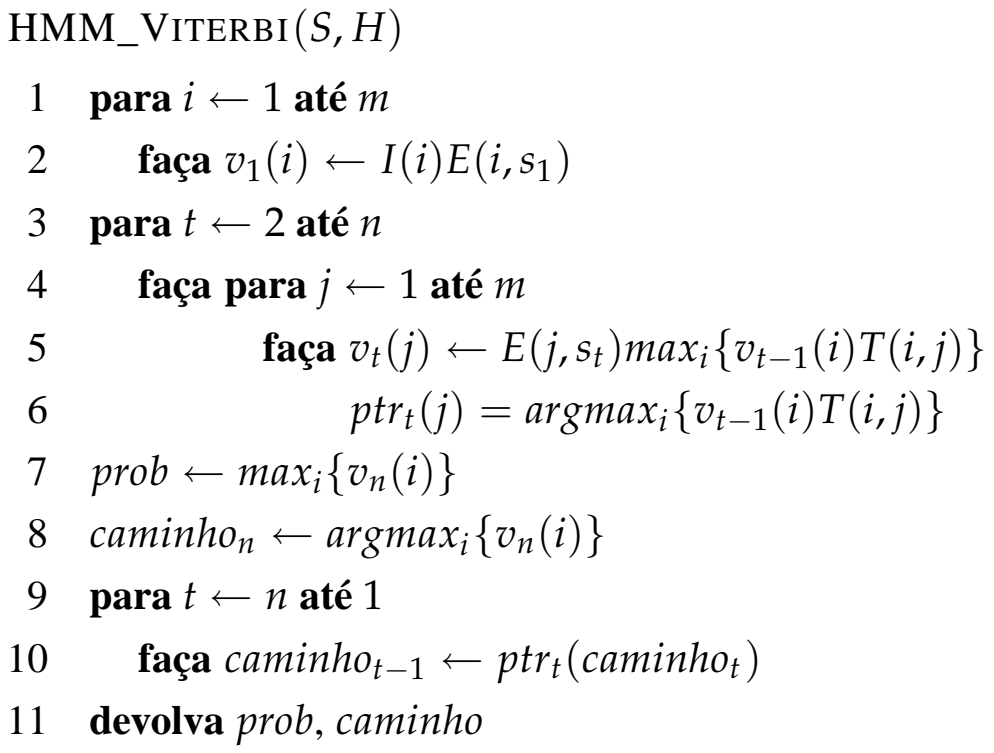

\subsection{Cadeia oculta generalizada de Markov}

Na Figura 4.6, há uma representação de uma cadeia oculta generalizada de Markov (GHMM - generalized hidden Markov model). Este modelo é construído a partir de uma cadeia de Markov em que a emissão é obtida simulando o modelo probabilístico associado com cada estado.

Figura 4.6: GHMM permite utilizar em cada estado um modelo probabilístico diferente representando a probabilidade de emissão de palavras.

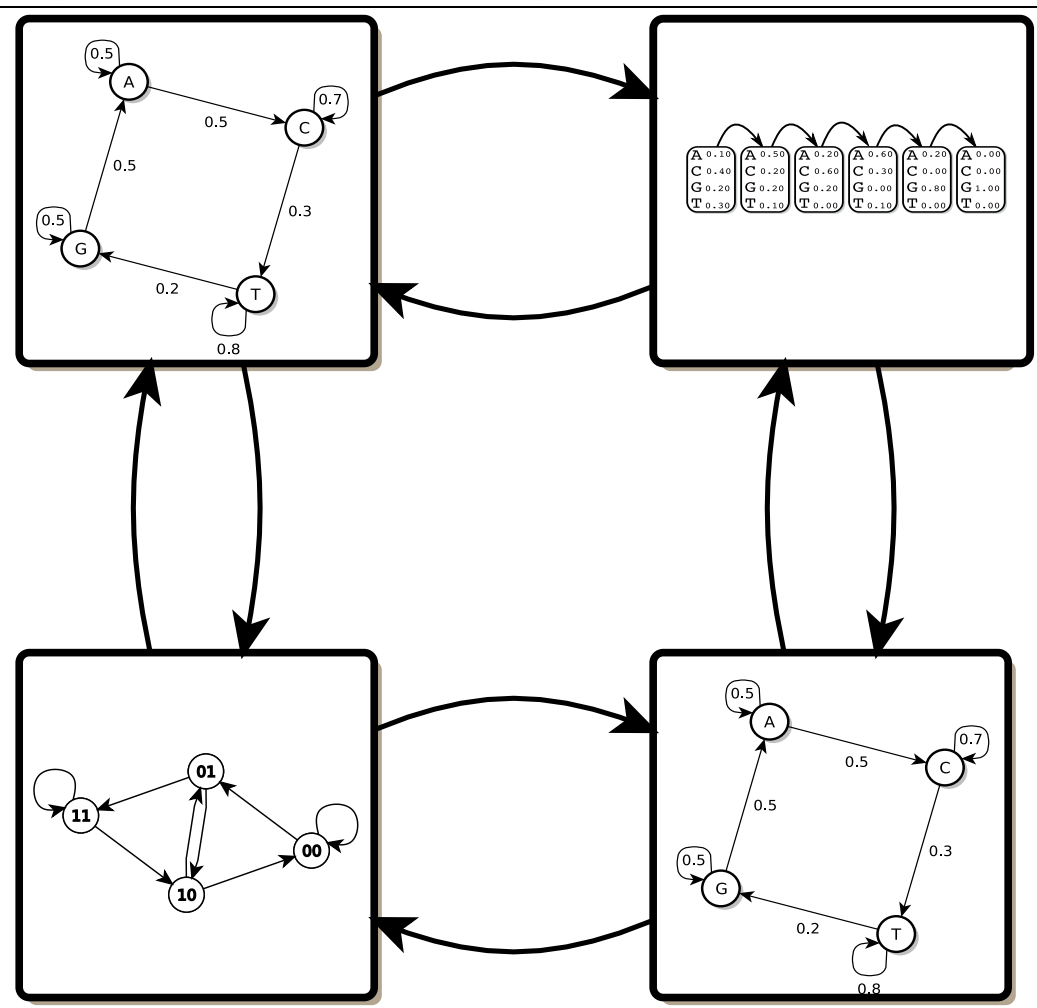


Para gerar uma palavra de tamanho $n$ utilizando uma GHMM, seguimos os seguintes passos [5, 9]:

1. O estado inicial $i$ é sorteado, e seja $j=i$ o estado atual.

2. Usando a distribuição de probabilidade de duração do estado $j$, uma duração $d$ é sorteada.

3. Usando o modelo probabilístico do estado $j$, é emitido uma palavra de tamanho $d$.

4. Usando a distribuição de transição de estados do estado $j$, é sorteado o próximo estado $k$.

5. Enquanto o tamanho da palavra formada pela concatenação das palavras emitidas for menor do que $n$, repita os passos $2,3,4$ e $5 \operatorname{com} j=k$.

6. No final, se o tamanho da palavra formada for maior do que $n$, então ela será truncada para ficar com tamanho $n$.

De forma mais formal, a cadeia oculta generalizada de Markov (GHMM) é formada por um par de processos estocásticos [21, 58]:

$$
\left(S_{0}, X_{0}\right),\left(S_{1}, X_{1}\right),\left(S_{2}, X_{2}\right), \cdots
$$

Em que o processo $\left\{X_{t}\right\}$ é uma cadeia homogênea de Markov, e o processo $\left\{S_{t}\right\}$ é a sequiência de variáveis aleatórias, cada $S_{t}$ recebe valores de um conjunto de palavras. Esses dois processos estão associados por uma mapeamento $S_{t}=e\left(X_{t}\right)$. Como $e$ pode ter o mesmo valor em estados diferentes, o processo oculto $\left\{X_{t}\right\}$ é observado de forma indireta através do processo $\left\{S_{t}\right\}[21]$.

A GHMM pode ser caracterizada por um conjunto finito, $Q$, de estados, uma matriz de transição $T$, e pela probabilidade de emissão $E$ que fornece a probabilidade de emitir a palavra $s_{i}$ dada a seqüência de estados $x_{0}, \ldots x_{i}$ e conhecendo a palavra que foi emitida $\tau=s_{0} \ldots s_{i-1}$ :

$$
E\left(x_{i-1}, x_{i}, \tau, s_{i}\right)=P\left(S_{i}=s_{i} \mid X_{0}=x_{0}, \ldots, X_{i}=x_{i}, S_{0}=s_{0}, \ldots, S_{i-1}=s_{i-1}\right)
$$

Em que, $x_{0}$ é o estado inicial, e $s_{0}$ é sempre o símbolo nulo.

Um caminho na GHMM é definido por uma seqüência de pares, em que cada par é formado por um estado $x_{i}$ e uma duração $d_{i}$. O vetor de pares $\theta=\left(\left(x_{1}, d_{1}\right),\left(x_{2}, d_{2}\right), \ldots,\left(x_{n}, d_{n}\right)\right)$ 
é chamado de caminho de comprimento $l$ se a soma de todas as durações deste caminho for $l$.

\subsubsection{Cálculo da probabilidade da seqüência dado o modelo}

Para calcular a probabilidade da sequiência dado o modelo, $P(S \mid G H M M)$, podemos utilizar uma abordagem parecida com aquela utilizada na cadeia oculta de Markov.

Vamos definir a probabilidade conjunta, $\alpha_{q, l}$, de emitir a palavra $S=s_{1} s_{2} \ldots s_{l}$ e do caminho terminando no estado $q$ [58]. O valor de $\alpha_{q, l}$ pode ser calculado utilizando uma fórmula parecida com aquela que vimos para HMM. Em vez de emitir um símbolo, a GHMM emite uma palavra. Assim, é necessário fazer a soma de todos os comprimentos $l^{\prime}$ possíveis:

$$
\alpha_{q, l}=\sum_{1 \leq l^{\prime}<l, q^{\prime} \in Q \text { ou } q^{\prime}=q_{0}, l^{\prime}=0} \alpha_{q^{\prime}, l^{\prime}} T\left(q^{\prime}, q\right) E\left(q^{\prime}, q, s_{1} \ldots s_{l^{\prime}}, s_{l^{\prime}+1} \ldots s_{l}\right)
$$

O algoritmo forward consiste em calcular as variáveis $\alpha_{q, l}$ usando a programação dinâmica.

A probabilidade da palavra $S$ de tamanho $n$ dado o modelo GHMM vai ser fornecida pela soma de $\alpha_{q, n}$ para todos os estados $q$.

$$
P(S \mid G H M M)=\sum_{q \in Q} \alpha_{q, n}
$$

\subsubsection{Algoritmo de Viterbi}

Podemos resolver o problema de encontrar o caminho mais provável dado uma sequiência. Vamos definir a variável de Viterbi $\gamma_{q, l}$ usando uma fórmula parecida com aquela utilizada para calcular o valor de $\alpha_{q, l}$. Em vez de calcular uma soma, a probabilidade do melhor caminho é encontrada através de uma maximização:

$$
\gamma_{q, l}=\max _{1 \leq l^{\prime}<l, q^{\prime} \in Q \text { ou } q^{\prime}=q_{0}, l^{\prime}=0}\left\{\gamma_{q^{\prime}, l^{\prime}} T\left(q^{\prime}, q\right) E\left(q^{\prime}, q, s_{1} \ldots s_{l^{\prime}}, s_{l^{\prime}+1} \ldots s_{l}\right)\right\}
$$

O algoritmo GHMM_VITERBI [58] devolve o caminho mais provável. O primeiro passo deste algoritmo é o de calcular cada entrada da matriz $\gamma_{q, l}$. A partir desta matriz o 
caminho mais provável é recuperado. Na linha 6 , o algoritmo está procurando o estado anterior que fornece a maior probabilidade para o caminho terminado em $q_{i-1}$ e que emitiu a palavra $s_{l+1} \ldots s_{i-1}$.

\section{GHMM_VITERBI $(S, G H M M)$}

1 Calcular e armazenar os valores de $\gamma_{q, l}$ para $q \in Q, 1 \leq l \leq n$

$2 q_{1} \leftarrow \operatorname{argmax}_{q \in Q} \gamma_{q, n} T\left(q, q_{\text {final }}\right)$

$3 \quad l_{1} \leftarrow n$

$4 \quad i \leftarrow 2$

5 enquanto $l_{i-1}>0$

6 faça $\left(q_{i}, l_{i}\right) \leftarrow \operatorname{argmax}_{(q, l) \in Q \times\left[1, l_{i-1}\right) \cup\left\{\left(q_{0}, 0\right)\right\}} \gamma_{q, l} T\left(q, q_{i-1}\right) E\left(q, q_{i-1}, s_{1} \ldots s_{l}, s_{l+1} \ldots s_{i-1}\right)$

$7 \quad i \leftarrow i+1$

$8 n \leftarrow i-2$

$9 \operatorname{devolva} \theta \leftarrow\left(\left(q_{n}, l_{n}-l_{n+1}\right), \ldots\left(q_{1}, l_{1}-l_{2}\right)\right)$

Este algoritmo utiliza $O(|Q| n)$ de memória, em que $n$ é o tamanho da seqüência, e o tempo de execução depende de como é calculado a probabilidade de emissão. Geralmente, a probabilidade de emissão pode ser pré-calculada em tempo $O(n)$ e recuperada em tempo constante $[35,59,9,5]$. Existem diferentes variações deste algoritmo que utilizam tempo linear [58, 5, 35]. Para obter esta complexidade, é utilizado diversas heurísticas tal como supor que a GHMM tem dois tipos de estados: estado com duração geométrica e estado com duração explícita. Esses dois tipos de estados devem estar organizados de tal forma que um caminho na GHMM é formado por uma seqüência de estados que não tem dois estados diferentes do mesmo tipo consecutivos [5]. Uma outra heurística é a utilização dos sensores de sinais para reconhecer pontos na seqüência que definem fronteiras entre duas regiões. Neste caso, o algoritmo precisa processar apenas as regiões potenciais definidas pelos sensores de sinais. 
44 CAPÍTULO 4. MODELOS PROBABILÍSTICOS PARA A PREDIÇÃO DE GENES 


\section{Capítulo 5}

\section{O sistema MYOP}

Ao analisar os diferentes preditores de genes, verificamos que muitos têm o modelo de genes fixado. Uma exceção é o sistema Tigrscan que permite escolher um modelo probabilístico para cada estado, mas não permite utilizar uma topologia diferente. A vantagem de deixar a topologia fixada é que o algoritmo de decodificação pode ser planejado especificamente para ela facilitando a implementação de soluções rápidas. A desvantagem é que devemos alterar o código de um programa existente ou implementar um novo programa para investigar uma nova variação de modelo de genes.

Quando queremos estudar os programas preditores de genes, uma das dificuldades encontrada é a impossibilidade de comparar cada abordagem de forma justa, pois não sabemos a relação entre o conjunto de treinamento e o conjunto de teste [68]. A maior parte das avaliações [28, 48, 43, 7] não fazem o treinamento de cada modelo de gene, e utilizam no conjunto de teste anotações recentes para evitar genes que estão no conjunto de treinamento de cada programa [48]. Essas avaliações mostram diferenças entre os programas, mas não deixam claro as diferenças de cada modelo: eles estão comparando preditores com topologias diferentes que utilizam modelos diferentes e que foram treinados com um conjunto de treinamento diferente.

Além disso, configurar uma GHMM é uma tarefa complicada e que está sujeita a muitas falhas. A possibilidade de utilizar cada modelo individualmente permite a identificação de modelos que não estão funcionando corretamente. Porém, nenhum programa citado documenta esta possibilidade.

Por esses motivos, escolhemos pela implementação de um novo sistema, MYOP (Make Your Own Predictor), que permite configurar diferentes modelos de genes, utilizar cada modelo individualmente, e comparar de forma justa a influência de cada modelo probabilístico em uma dada topologia. 


\subsection{Utilizando o MYOP}

Na Figura 5.1, estamos descrevendo os passos necessário para configurar a GHMM no sistema MYOP. Primeiro, o conjunto de treinamento de cada região é obtido. Depois, um modelo probabilístico de cada região e sinal biológico é treinado. Finalmente, o conjunto de modelos é mapeado na topologia de uma GHMM.

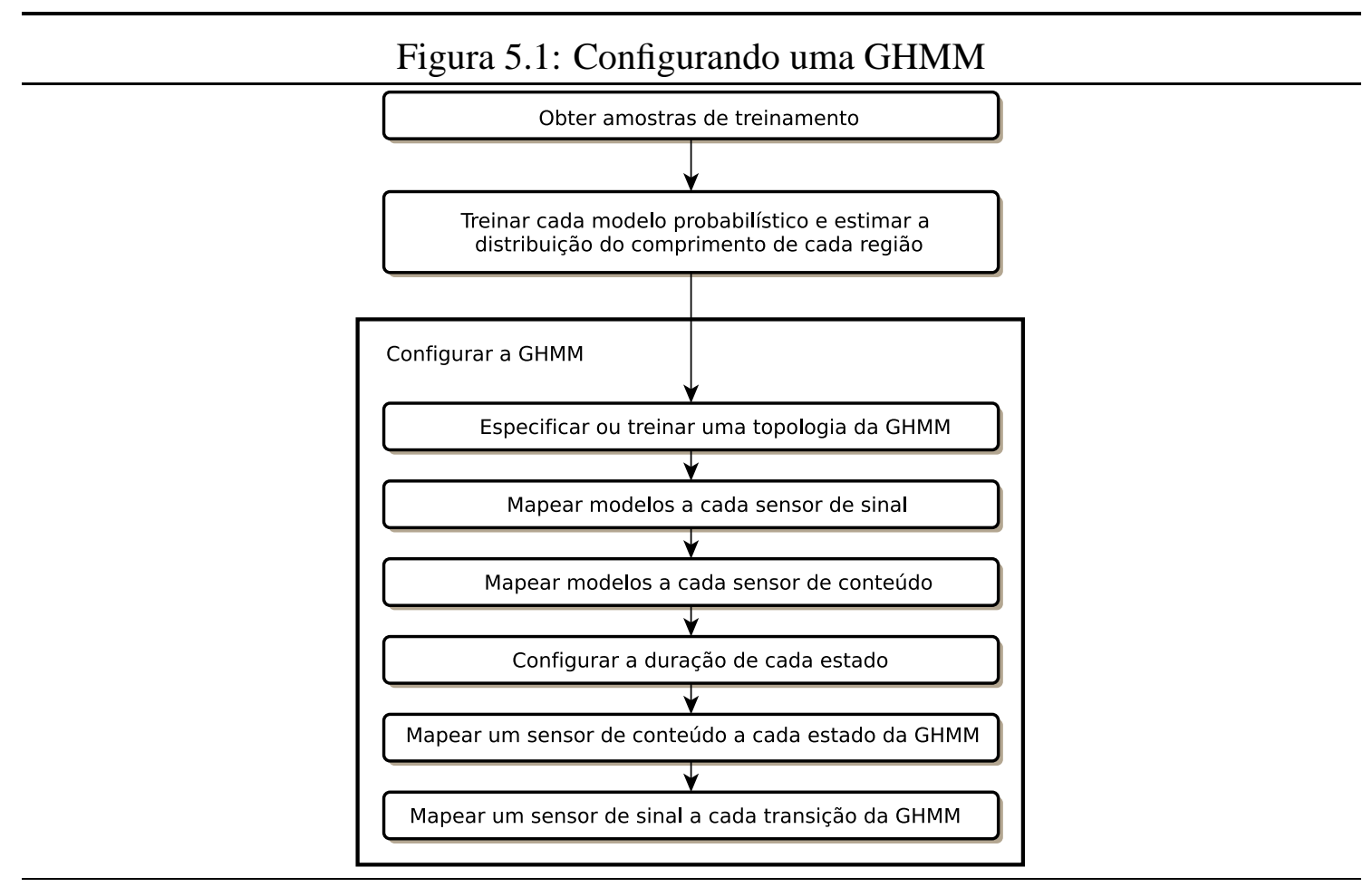

\section{Amostras de treinamento}

Para treinar cada modelo probabilístico, começamos com dois arquivos: "train.fasta" e "train.gff". O primeiro arquivo tem as seqüências que serão utilizadas, o segundo arquivo tem a localização de cada região. A partir desses dois arquivos, podemos extrair as seqüências de cada região ou sinal que servirá como amostra para estimar cada modelo.

\section{Construindo cada modelo}

A partir de uma amostra de treinamento, podemos estimar cada parâmetro de um modelo probabilístico. Note que cada modelo pode ter diferentes algoritmos de construção. Por exemplo, no sistema MYOP, é possível estimar os parâmetros da cadeia de Markov por máxima verossimilhança, ou podemos fornecer explicitamente cada estado e a matriz de transição. 


\section{Configurando a GHMM}

Após estimar cada modelo, podemos configurar uma GHMM seguindo os passos:

1. indicamos quais modelos serão utilizados;

2. configuramos os sensores de conteúdo, indicando o modelo de cada sensor de conteúdo;

3. configuramos os sensores de sinais, indicando o modelo negativo e o modelo positivo de cada sensor de sinal;

4. configuramos cada estado da GHMM, associando cada estado a um sensor de conteúdo;

5. configuramos as transições, associando cada transição a um sensor de sinal.

Os detalhes de cada arquivo de configuração da GHMM estão no Apêndice A.3.

\section{Ferramentas do MYOP}

A Figura 5.2 mostra os programas utilizados para gerar cada modelo que será utilizado pela GHMM:

- seqparser recebe um arquivo no formato GFF (gene finding format ou general feature format) e um arquivo no formato FASTA e separa cada região em arquivos diferentes de acordo com a especificação fornecida no arquivo de configuração.

- build_model serve para obter um modelo probabilístico. Este programa tem dois parâmetros obrigatórios, o nome do modelo de saída, e o tipo de modelo que vai ser estimado. Os outros parâmetros são específicos de cada algoritmo de construção: a ordem da cadeia de Markov, a amostra de treinamento, a duração de cada estado, e outros.

Note que podemos utilizar o mesmo modelo em muitos estados. O modelo "coding.model" pode ser utilizado em todos os estados do tipo éxon, e o modelo "noncoding.model" pode ser utilizado em todos os estados do tipo íntron ou região intergênica.

A matriz de transição da GHMM pode ser obtida de duas formas. Na primeira, o usuário especifica cada estado e probabilidade de transição utilizando um arquivo no formato 
Figura 5.2: Cada octágono representa um programa, e cada retângulo um arquivo. A partir dos arquivos "train.gff" e "train.fasta", obtemos outros arquivos no formato FASTA, cada um contendo sequiências de um mesmo tipo de região. O programa "seqparser" recebe um arquivo de configuração, "parser.cnf", indicando as regras de como extrair cada amostra. Cada arquivo gerado pelo seqparser serve como entrada para o programa build_model que recebe um arquivo de configuração e devolve um modelo. Cada modelo pode ser analisado individualmente, ou associado a um estado da GHMM. Devemos destacar que podemos ter um mesmo modelo associado a muitos estados diferentes. Neste caso, os estados do tipo éxons utilizam o modelo "coding.model", e os estados do tipo íntron e região intergênica utilizam o modelo "noncoding.model".

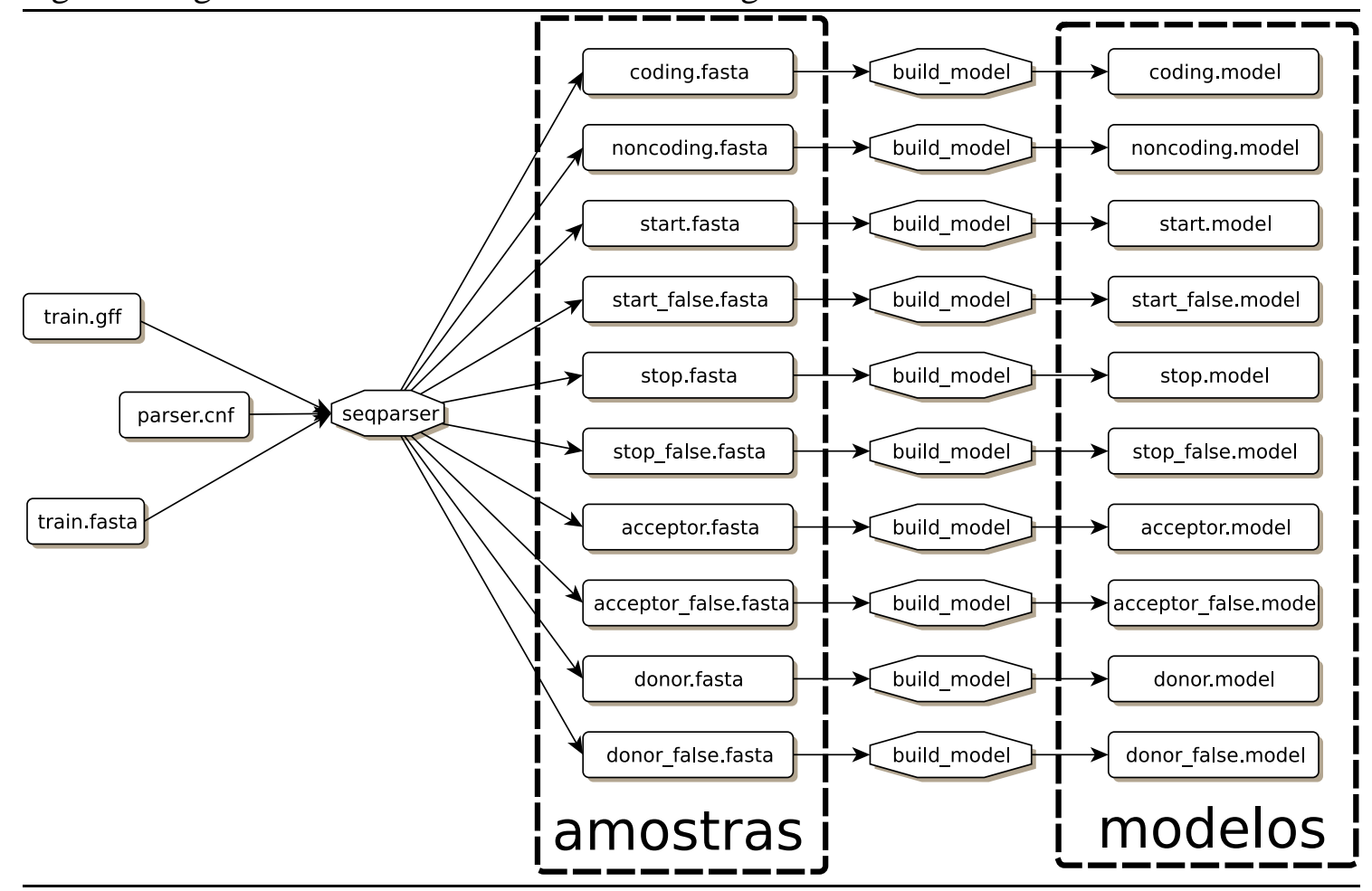


TGF (trivial graph format). A segunda consiste em estimar cada probabilidade de transição utilizando a informação contida no arquivo GFF. Para esse tarefa, podemos utilizar o programa get_transition_distribution.

Para estimar a probabilidade da duração de cada estado, podemos utilizar o programa smoothed_sojourn. Este programa recebe um arquivo FASTA com sequiências da região e devolve a distribuição suavizada do comprimento.

Após configurar uma GHMM, podemos aplicar o programa gene_prediction para obter predições de genes. Ele recebe a especificação da GHMM e um arquivo FASTA e para cada seqüência ele devolve uma estrutura do gene.

Finalmente, cada modelo estimado pode ser utilizado individualmente. Podemos simular o modelo utilizando o programa generate_sequence o qual gera seqüências por simulação, ou podemos calcular a razão log-odds de cada seqüência de um arquivo FASTA usando o programa score_sequence. Esses dois programas podem ser utilizados para verificar se o modelo foi estimado corretamente.

\subsection{Componentes do MYOP}

Os principais componentes do sistema MYOP são os modelos probabilísticos que estão representados na Figura 5.3. A classe abstrata SentenceStochasticModel ${ }^{1}$ fornece a interface de um modelo probabilístico que pode ser implementado no sistema.

Figura 5.3: Diagrama de classes no formato UML (unified modeling language) dos modelos probabilísticos do MYOP. O triângulo indica a relação de herança; e o diamante a relação de agregação: cada modelo é um SentenceStochasticModel.

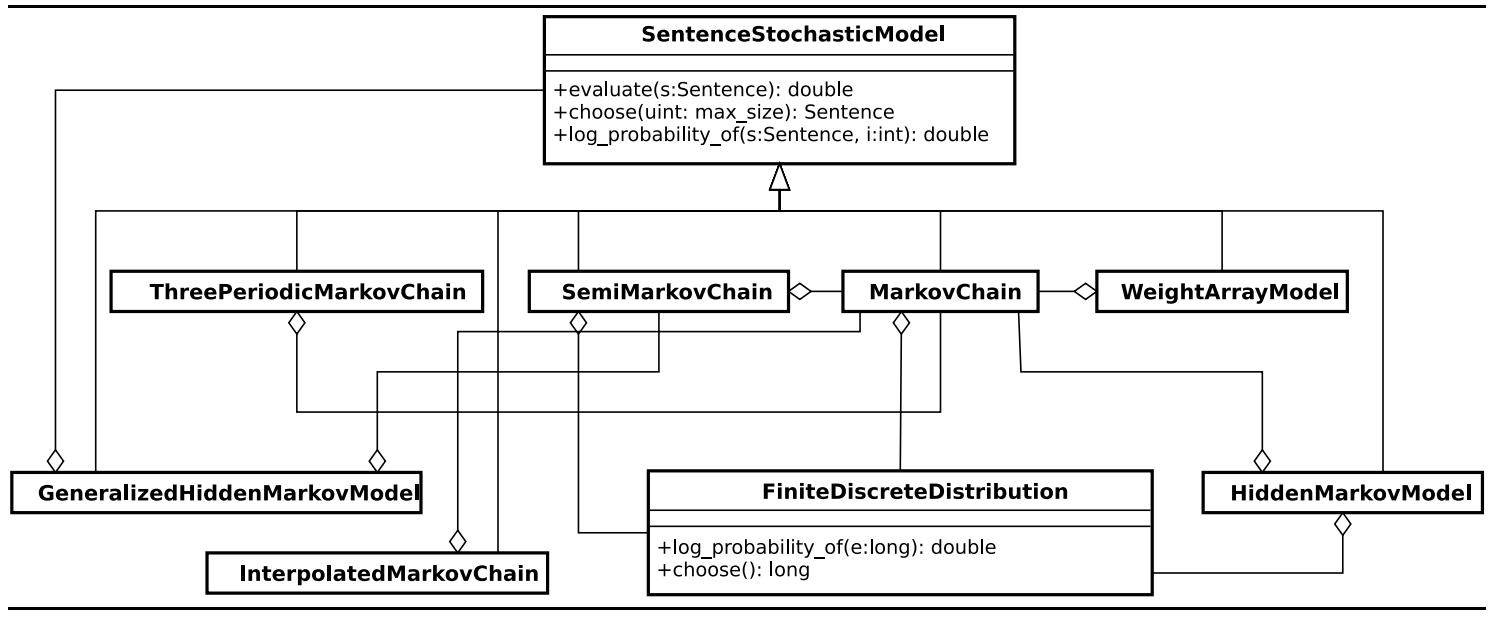

Todos os modelos probabilísticos do MYOP são construídos direta ou indiretamente através de um conjunto de distribuições de probabilidade finitas e discretas. A classe

\footnotetext{
${ }^{1}$ A classe abstrata SentenceStochasticModel tem os métodos choose e evaluate. O método choose serve para simular o modelo, e o evaluate calcula a probabilidade de uma sequiência.
} 
que fornece a abstração de uma distribuição é chamada de FiniteDiscreteDistribution ${ }^{2}$. Esta classe representa uma distribuição finita, pois ela utiliza uma tabela para armazenar a probabilidade de cada elemento. Um objeto desta classe representa uma distribuição de probabilidade sobre um conjunto de números inteiros.

Os modelos probabilísticos do sistema são implementações de uma SentenceStochasticModel:

- MarkovChain é a cadeia homogênea de Markov. Cada estado de uma MarkovChain tem um objeto FiniteDiscreteDistribution, indicando a probabilidade de transição que tem como origem este estado e destino um outro estado.

- InterpolatedMarkovModel é a cadeia de Markov interpolada. Ele é construída a partir de uma MarkovChain.

- WeightArrayMethod é a implementação dos modelos WMM e WAM. Se o objeto WeightArrayMethod for de ordem zero então é um modelo do tipo WMM, caso contrário ele é um modelo do tipo WAM. Para cada posição do modelo WAM, existe uma MarkovChain representando a distribuição posicional das bases;

- ThreePeriodicMarkovChain é a cadeia de periodicidade três de Markov. Para cada uma das três posições, há uma MarkovChain que representa a distribuição posicional das bases;

- HiddenMarkovModel é a cadeia oculta de Markov. Este modelo é constituído por uma MarkoChain, e uma FiniteDiscreteDistribution que representa a probabilidade de emissão de um símbolo;

- SemiMarkovChain é a cadeia semi-markoviana. Este modelo é formado por uma MarkovChain onde a duração do estado é dada de forma explícita através de objetos FiniteDiscreteDistribution;

- GeneralizedHiddenMarkovModel é a cadeia oculta generalizada de Markov, formada por uma SemiMarkovChain e por outros SentenceStochasticModel representando a probabilidade de emissão.

\subsection{Validação dos modelos e teste de unidade}

Para fazer a validação dos modelos implementados exploramos a capacidade de simulação do sistema MYOP. Cada algoritmo de simulação está descrito no Apêndice B. Começamos com dois modelos do mesmo tipo: o primeiro modelo tem parâmetros fixados

\footnotetext{
${ }^{2}$ A classe FiniteDiscreteDistribution possui o método log_probability_of que devolve a probabilidade de um elemento, e um método choose que escolhe um elemento da distribuição.
} 
manualmente; o segundo modelo será treinado. Utilizando o primeiro modelo geramos uma amostra de treinamento por simulação, cada sequiência desta amostra tem tamanho fixo. Esta amostra é utilizada para treinar os parâmetros do segundo modelo. É de esperar que após o treinamento, ambos os modelos representem uma distribuição de probabilidade semelhante.

Para verificar se as distribuições são semelhantes, é gerado uma amostra, $A=\left\{x_{1}, \ldots x_{n}\right\}$, de palavras com tamanho fixo usando o modelo que foi treinado. Usando o teste $\chi^{2}$ podemos testar se o primeiro modelo representa a distribuição de probabilidade que está na amostra [51].

Em outras palavras, a hipótese a ser testada chamada de hipótese nula $H_{0}$ é:

$$
H_{0}: P\left(X=x_{i}\right)=p_{x_{i}}, x_{i} \in A
$$

Em que $p_{x_{i}}$ é a probabilidade da palavra $x_{i}$ dado o modelo original. Para testar esta hipótese, seja $N_{x_{i}}$ o número de palavras iguais a $x_{i}$ na amostra $A$. Como cada variável $X_{i}$ é independentemente igual à $x_{i}$ com probabilidade $P\left(X=x_{i}\right)$, segue que sobre a hipótese nula, $N_{x_{i}}$ é uma binomial com parâmetros $n$ e $p_{x_{i}}$. Assim, quando $H_{0}$ é verdadeira temos:

$$
E\left[N_{x_{i}}\right]=n p_{x_{i}}
$$

e quando o valor de $\left(N_{x_{i}}-n p_{x_{i}}\right)^{2}$ é alto obtemos uma indicação de que $H_{0}$ não é correto. Então, podemos utilizar a seguinte estatística para o teste:

$$
T=\sum_{i=1}^{n} \frac{\left(N_{x_{i}}-n p_{x_{i}}\right)^{2}}{n p_{x_{i}}}
$$

A hipótese nula é rejeitada quando o valor de $T$ é alto. Para números grandes de $n, T$ é aproximadamente uma distribuição chi-quadrado com $n-1$ graus de liberdade.

Este processo de validação pode ser automatizado para sequiências de tamanho pequeno. No sistema MYOP, a validação é feita através da implementação de testes de unidade [2] os quais são executados sempre que modificamos o sistema.

\subsection{Detalhes de implementação do MYOP}

O sistema MYOP foi implementado utilizando diversos padrões de projetos descritos no livro Desing Patterns: Elements of reusable object-oriented software [20]: 
- Factory. Define uma interface para criar um objeto. Utilizamos este padrão para possibilitar a criação de diferentes tipos de objetos do tipo FiniteDiscreteDistribution e Alphabet;

- Builder. Separa a construção de um objeto complexo de tua representação de tal forma que o mesmo processo pode criar diferentes representações;

- Memento. Serve para salvar e recuperar o estado de um objeto;

- Strategy. Permite o intercâmbio de diferentes algoritmos.

Embora implementado em $\mathrm{C}++$, o sistema pode ser utilizado como um módulo Python que facilita a prototipagem de pequenos programas.

\subsubsection{Fábricas de distribuições discretas de probabilidade}

O sistema MYOP tem uma fábrica [20] de distribuições discretas finitas de probabilidade chamada de FiniteDiscreteDistributionFactory. Essa classe implementa métodos que servem para gerar, usando diferentes abordagens, objetos do tipo FiniteDiscreteDistribution. Os seguintes algoritmos estão implementados nesta fábrica:

- smoothedDistributionBurge(data, C). É o algoritmo de suavização descrito em [5].

- smoothedDistributionKernelDensity(data). É o algoritmo que utiliza a estimação de densidade pela função núcleo.

- uniform(begin, end). Gera uma distribuição uniforme com números inteiros no intervalo [begin, end].

\subsubsection{Fábricas de alfabetos}

O sistema tem uma classe chamada de Alphabet que representa um alfabeto qualquer. Além disso, a classe (AlphabetFactory) fornece diferentes alfabetos amplamente utilizados.

A classe AlphabetFactory tem os seguintes métodos:

- iupac_dna() devolve um alfabeto, segundo o padrão IUPAC, representando as bases de DNA.

- iupac_aminoacids() devolve um alfabeto, segunda a IUPAC, representando os aminoácidos. 
- custom_alphabet $(s)$ recebe uma palavra $s$ contendo os símbolos do alfabeto separados por caracteres “|”. Por exemplo, quando o método recebe "a|c|g|t”, ele devolve um alfabeto de quatro letras $\{a, c, g, t\}$.

\subsubsection{Construtores de modelos probabilísticos}

Utilizamos o padrão de projeto Builder para possibilitar a implementação de diferentes maneiras de construir um modelo probabilístico. Esse padrão de projeto separa a construção de um objeto complexo de tua representação de tal forma que o mesmo processo pode ser utilizado para construir representações diferentes [20]. Em outras palavras, podemos ter diferentes formas de construir instâncias de um mesmo tipo de modelo probabilístico.

Eventualmente, podemos implementar diferentes algoritmos de treinamento para um mesmo modelo. Por exemplo, para a construção de uma cadeia oculta de Markov podemos utilizar máxima verosimilhança se o processo oculto é conhecido, ou o algoritmo Baum-Welch [45] quando não conhecemos o processo oculto.

Em particular, os parâmetros de uma cadeia de Markov podem ser fornecidos utilizando um arquivo para representar grafos. Um formato amplamente utilizado é o TGF (trivial graph format). Editando um arquivo neste formato, podemos definir os parâmetros da cadeia de Markov e utilizando um objeto da classe TGFMarkovChainBuilder podemos construir um objeto do tipo MarkovChain. A Figura 5.4 mostra como podemos ter diferentes algoritmos para a construção de uma MarkovChain: a classe abstrata MarkovChainBuilder fornece a interface necessária para esta tarefa. A mesma idéia é aplicada para outros modelos.

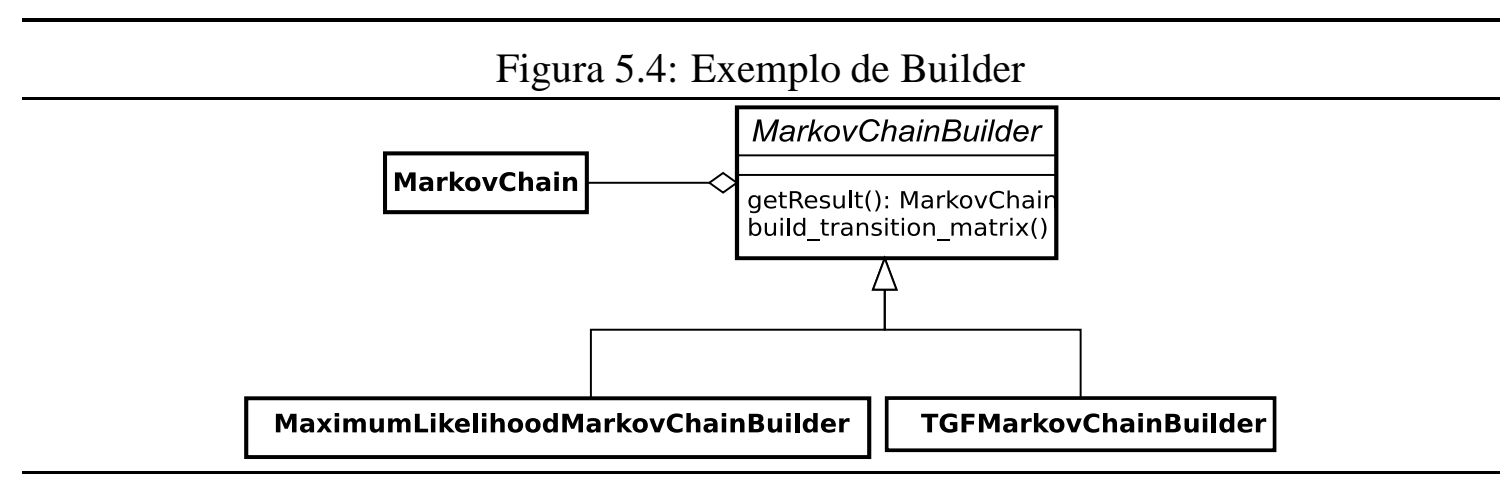

\subsubsection{MYOP e Python}

Embora programado em $\mathrm{C}++$, os objetos do MYOP podem ser utilizados na linguagem Python, facilitando o processo de prototipagem de uma nova abordagem: para utilizar as componentes do MYOP não precisamos programar em $\mathrm{C}++$. 
O exemplo a seguir, mostra como podemos utilizar o MYOP usando a linguagem Python: construímos um alfabeto usando a fábrica de alfabetos; uma nova seqüência é construída; um modelo é carregado a partir de um arquivo; e a probabilidade da seqüência é calculada.

\section{\#! /usr/bin/env python}

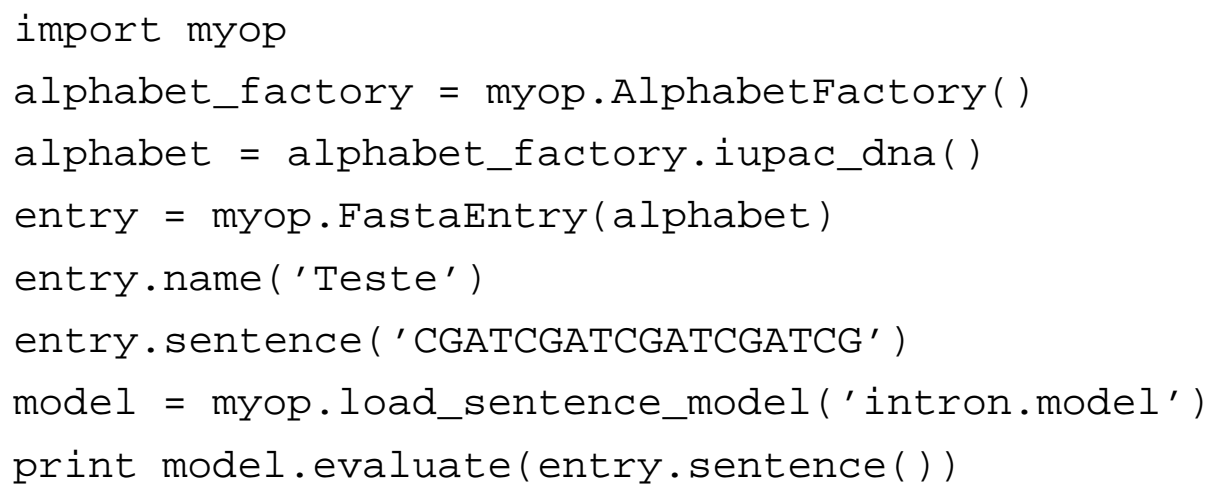

\subsubsection{Ferramentas utilizadas}

O sistema MYOP foi implementado na linguagem $\mathrm{C}++$ e foi utilizado as seguintes bibliotecas do projeto BOOST ${ }^{3}$ (versão 1.33.1).: regex fornece suporte a expressão regular; smart pointer serve para evitar vazamento de memória; serialization permite a serializar objetos em $\mathrm{C}++$; Boost test library é um arcabouço para realizar testes de unidade; e Boost.python para possibilitar o uso dos objetos C++ na linguagem Python (versão 2.3). Além disso, fizemos a documentação do sistema usando Doxygen (versão 1.4.2) ${ }^{4}$.

O sistema MYOP roda no sistema operacional Linux. Em particular, ele foi testado com a distribuição Debian Sarge e com a distribuição Ubuntu 6.10.

\footnotetext{
${ }^{3}$ BOOST fornece bibliotecas $\mathrm{C}++$ portáveis que passam por um processo de peer-review antes de serem publicadas. Essas bibliotecas podem ser adquiridas em http://www.boost.org/. BOOST também é fornecido em pacotes presentes em qualquer distribuição Linux

${ }^{4}$ Doxygen é um sistema de documentação que suporta diversas linguagens, inclusive $\mathrm{C}++$. Ele analisa os comentários presentes no código-fonte e gera uma documentação em HTML, bem como um manual em LETEX. Doxygen pode ser encontrado em pacotes presentes em qualquer distribuição Linux, ou através da página http://www.stack.nl/ dimitri/doxygen/
} 


\section{Capítulo 6}

\section{Um exemplo de uso do MYOP}

O sistema MYOP é uma ferramenta para investigar em detalhe os diferentes aspectos de modelos de genes. Cada modelo de gene é constituído por uma topologia e para cada estado da topologia esta associado um modelo probabilístico. Note que podemos implementar qualquer topologia que vimos no Capítulo 3, e podemos explorar os modelos de genes equivalentes aos modelos dos preditores: GeneMark; Genscan; Glimmer; Augustus; Tigrscan; e GeneMark.hmm. Esses preditores utilizam os mesmos modelos probabilísticos implementados no MYOP e possuem os melhores resultados em diversas avaliações [28, 48, 43, 7].

Neste capítulo procuramos demonstrar a utilidade do MYPO como ferramenta de estudo, fazendo uma exploração preliminar da topologia de três preditores: GlimmerHMM (similar à do TigrScan), Phat e GeneMark.hmm. Escolhemos essas três topologias porque elas modelam os mesmos elementos do gene utilizando uma topologia diferente. GlimmerHMM é a topologia mais simples tem um estado para éxon inicial e um estado para éxon final. Phat tem três estados para éxon inicial na fita direta, e três estados para éxon final na fita reversa. GeneMark.hmm tem três estados para éxon inicial, três para éxon final, e 18 estados para éxon interno. Não fizemos a modelagem para as regiões não condificadoras 5'e 3', nem dos promotores e sítios de poliadenilação, para reduzir o número de variáveis e de configurações finais nesta primeira avaliação. Utilizando essas três topologias, estudamos a influência de dois modelos probabilísticos para a região codificadora e dois tipos de modelo para cada um dos 4 sinais biológicos (sinal de aceitação, sinal de doação, sinal de iniciação e sinal de terminação). Estas variações determinam um total de 96 modelos de genes ${ }^{1}$, os quais foram treinados e avaliados utilizando os programas do sistema MYOP.

Como já mencionamos antes, quando os preditores implementam diretamente a topologia do analisador, várias heurísticas podem ser utilizadas para melhorar a predição.

\footnotetext{
$12 * 2^{4} * 3=96$
} 
Porém isso dificulta uma comparação direta das várias topologias. Acreditamos que o desenvolvimento de preditores mais eficientes deve se iniciar pelo estudo das topologias em seu estado mais "puro" para, posteriormente, ser realizado um estudo da inclusão das várias heurísticas de maximização de performance. Para uma estimativa inicial da importância destas heurísticas, avaliamos também os preditores GlimmerHMM e Tigrscan com a mesma amostra de treinamento e teste utilizada para os 96 modelos descritos acima.

Um detalhe importante, a especificação da arquitetura, o treinamento dos modelos e os testes de avaliação foram feitos em apenas 2 dias. Como veremos abaixo, mesmo num tempo tão exíguo foi possível obter resultados animadores no sentido de indicar novos caminhos para o desenvolvimento de novos preditores de genes.

\subsection{Amostra de genes}

Todos os modelos de genes foram avaliados utilizando o par de amostra de treinamento, e de validação desenvolvido por D. Kulp (University of California at Santa Cruz) e M. G. Reese (Lawrence Berkeyley National Laboratories) em 1995. Este par de amostras pode ser obtido no seguinte endereço ftp://ftp.cse. ucsc.edu/pub/dna/genes/. A amostra de treinamento tem 304 genes e a de validação tem 65 genes. Todos os genes possuem sinais com seqüências conservadas canônicas: GT para sítio doador; AG para sítio aceitador; ATG para sinal de início de tradução; TAA, TAG, TGA para sinal de fim de tradução.

\subsection{Topologias testadas}

Testamos três topologias de três preditores de genes: GlimmerHMM (Figura 6.1); Genemark.hmm (Figura 6.3); e Phat (Figura 6.2). Escolhemos essas topologias porque não preparamos amostras para o sítio de poliadenilação, o promotor e nem para as regiões $5^{\prime}$ e 3' não-codificadoras.

\subsection{Sensores de conteúdo avaliados}

Para representar a região codificadora, treinamos a cadeia de Markov com periodicidade três com ordem 5, e a cadeia interpolada de Markov com ordem 8. Para representar a região não-codificadora, treinamos uma cadeia de Markov homogênea e uma cadeia interpolada de Markov com ordem 8.

Cada estado do tipo éxon precisa de um modelo para a região codificadora, e cada estado do tipo íntron ou região intergênica precisa de um modelo para a região não- 


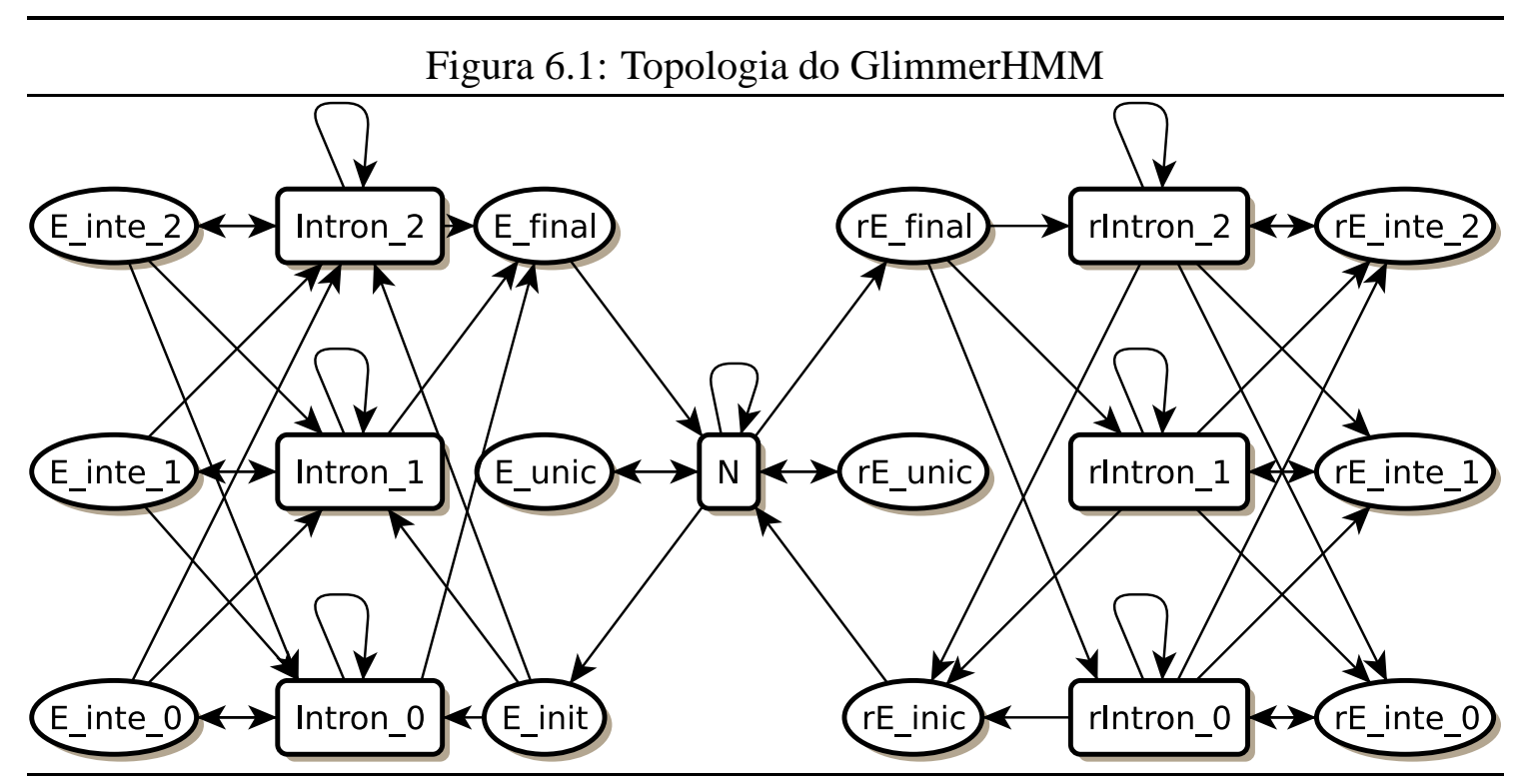

Figura 6.2: Topologia do Phat

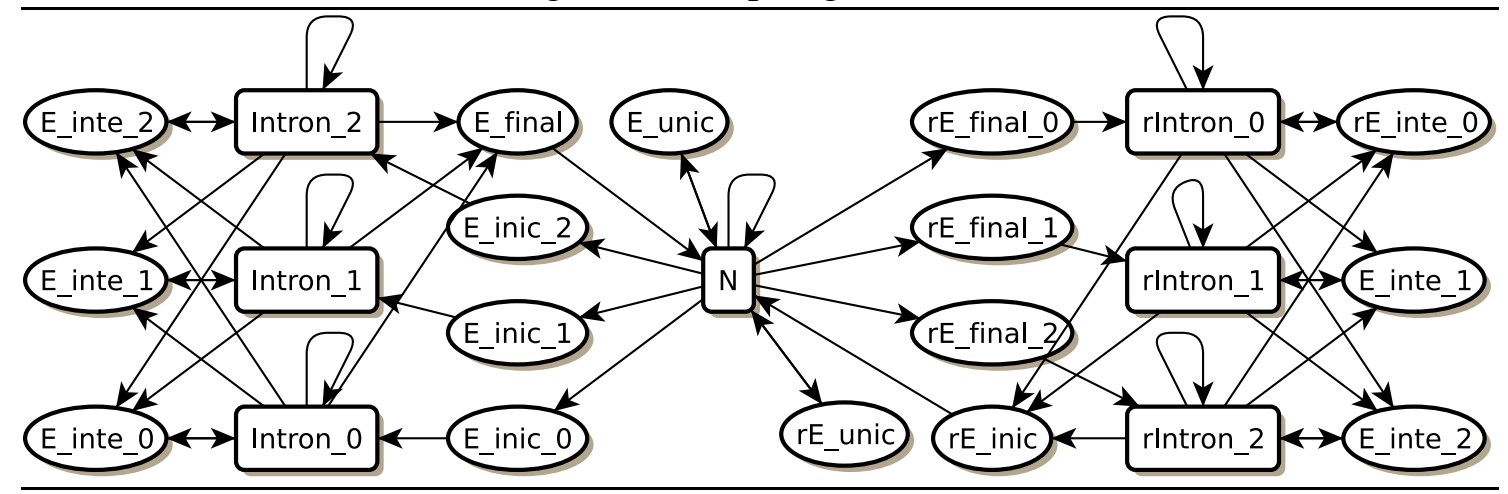

Figura 6.3: Topologia do Genemark.hmm

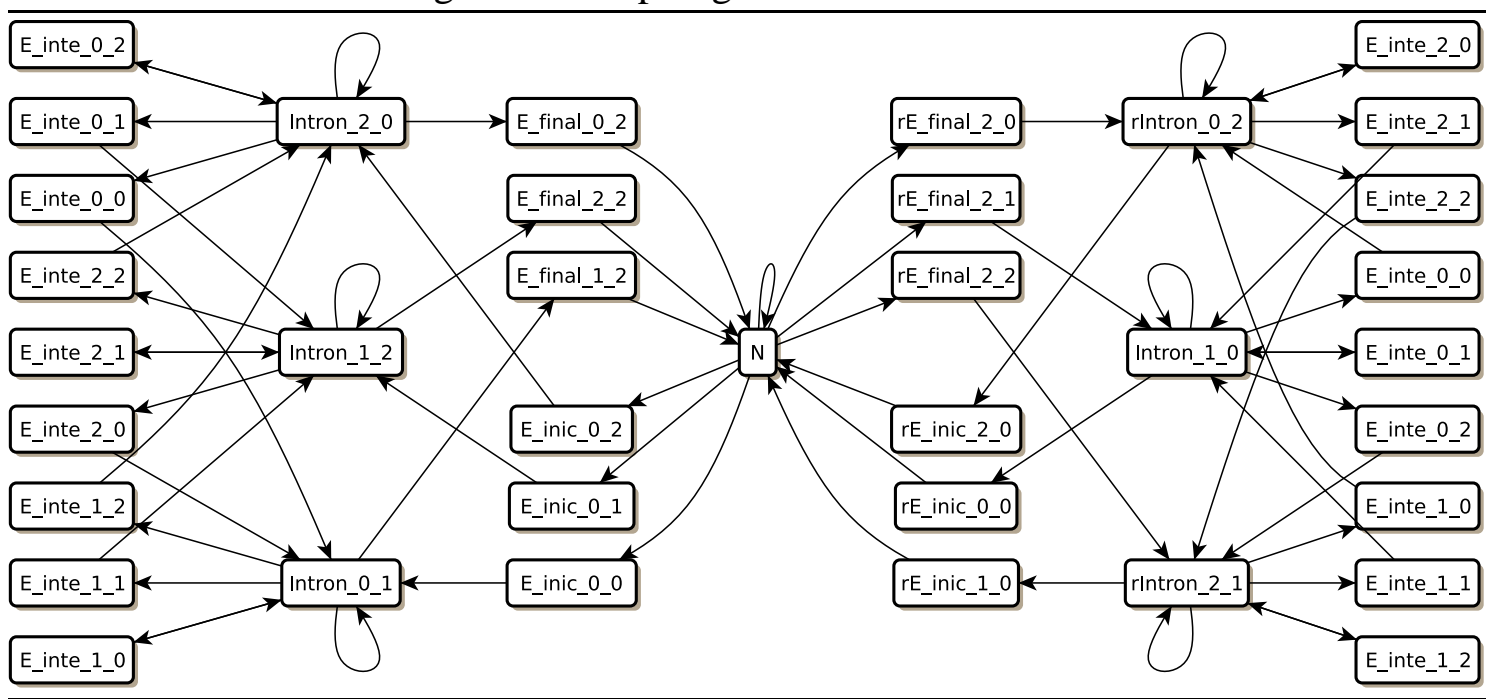


codificadora. Todas as vezes que aplicamos a cadeia de Markov homogênea para a região não-codificadora, utilizamos a cadeia de Markov com periodicidade três para a região codificadora. E todas as vezes que utilizamos a cadeia interpolada de Markov para a região não-codificadora, utilizamos também a cadeia interpolada de Markov com periodicidade três para a região codificadora.

\subsection{Sensores de sinais avaliados}

Cada modelo de gene tem quatro tipos de sinais biológicos: sítio de início de tradução, sítio de fim de tradução, sítio aceitador, e sítio doador. Para cada sinal biológico treinamos uma WAM de ordem 1 e uma WMM.

Na Tabela 6.1, mostramos a configuração das seqüências desses sinais. Na Tabela 6.2, apresentamos o tamanho de cada amostra de treinamento utilizada: sequiências de sinais truncadas foram ignoradas.

Tabela 6.1: Sinais que estão modelados no preditor. $\mathrm{A}$ notação $[A C G T]\{10\} A T G[A C G T]\{13\}$ significa que a sequiência da janela é constituída por dez bases seguido de ATG, seguido de 13 bases.

\begin{tabular}{lll}
\hline Sinal & Tamanho & Configuração da janela \\
\hline início de tradução & 26 bases & {$[A C G T]\{10\} A T G[A C G T]\{13\}$} \\
fim de tradução & 18 bases & {$[A C G T]\{10\}(T A A|T G A| T A G)[A C G T]\{5\}$} \\
sítio aceitador & 37 bases & {$[A C G T]\{30\} A G[A C G T]\{5\}$} \\
sítio doador & 12 bases & {$[A C G T]\{5\} G T[A C G T]\{5\}$} \\
\hline
\end{tabular}

Tabela 6.2: Tamanho da amostra de cada sinal

\begin{tabular}{lll}
\hline Sinal & Amostra positiva & Amostra negativa \\
\cline { 2 - 3 } início de tradução & 300 & 39844 \\
fim de tradução & 303 & 111216 \\
sítio aceitador & 1494 & 99099 \\
sítio doador & 1494 & 98508 \\
\hline
\end{tabular}

\subsection{Duração dos estados}

A Figura 6.4 mostra a distribuição do comprimento do éxon inicial, éxon interno, éxon final, e íntron. Repare que existem comprimentos que não aparecem na amostra, a suavização serve para preencher esses "espaços vazios". Utilizamos uma distribuição geométrica com média 964.04 para representar a distribuição do comprimento dos íntrons. 

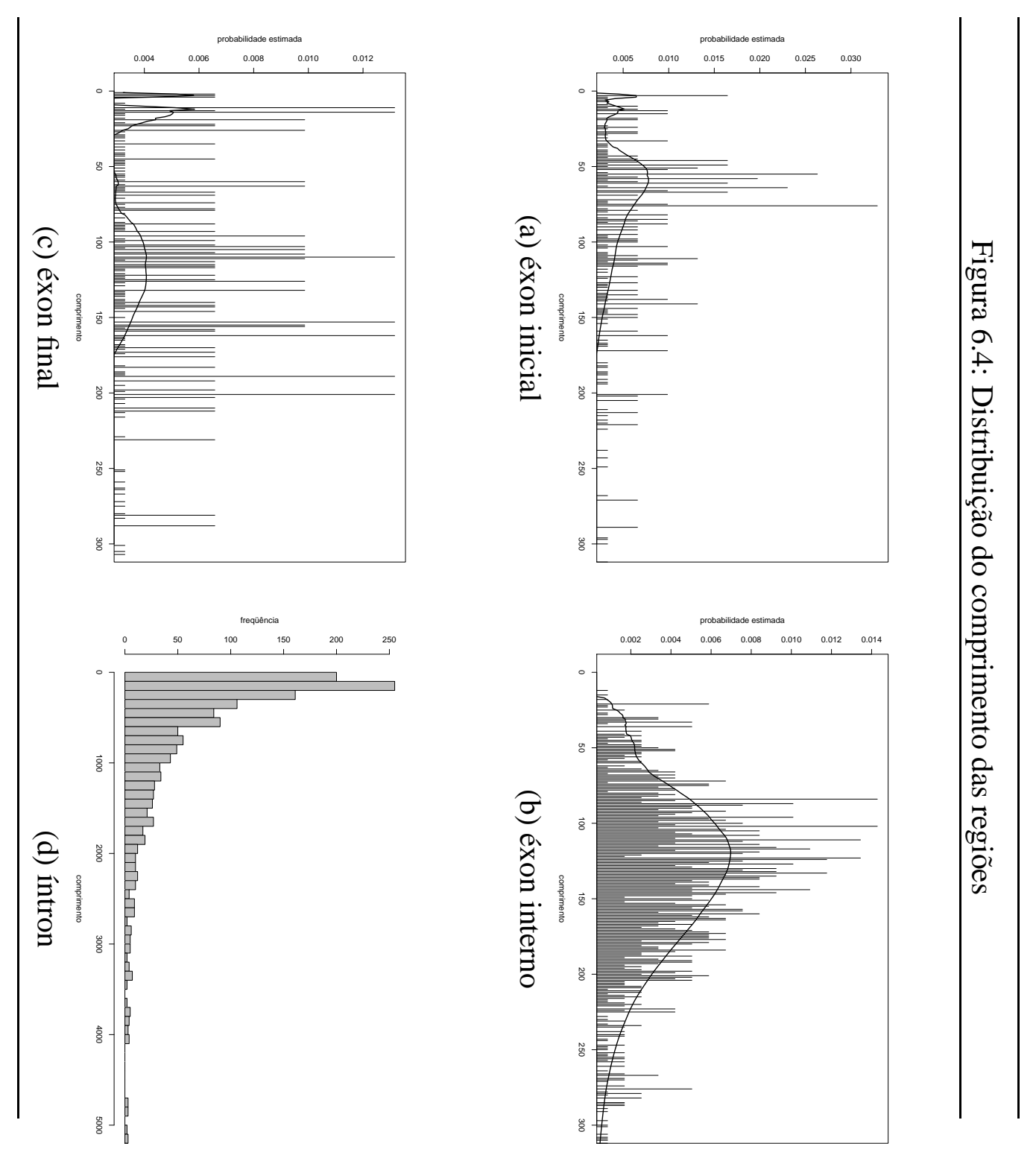


\subsection{Modelos de genes avaliados}

Implementamos 96 modelos de genes: testamos três topologias; para cada topologia, exploramos dois modelos para a região codificadora; e cada topologia representa quatro tipos de sinais biológicos e cada sinal foi representado por 2 modelos, testamos todas as 16 combinações de modelos e sinais.

Dentro do conjunto de 96 modelos, existe um modelo que deve ser equivalente ao GeneMark.hmm. Como não implementamos o MDD e nem a cadeia de alcance variável de Markov, não há nenhum modelo equivalente ao Phat e nem ao GlimmerHMM. O sensor de sinal para sítios de splicing do GlimmerHMM utiliza a informação da região codificadora combinada com o modelo MDD [44], e o sensor de sinal do Phat é formado por uma cadeia de alcance variável de Markov. Esses dois sensores serão implementados futuramente.

\subsection{Avaliação dos modelos de genes}

A exatidão de cada modelo de gene do MYOP foi calculada pelo programa Eval [27], a descrição de cada medida está no Apêndice C.1.

O preditor GlimmerHMM (versão 2.2.0) foi treinado com a mesma amostra utilizando o programa trainGlimmerHMM com os parâmetros padrão, nenhum tipo de ajuste manual foi realizado.

Modificamos a topologia do preditor Tigrscan (versão 1.0) removemos os estados para as regiões 5' não-codificadora, 3' não-codificadora, promotor e sinal de poliadenliação da topologia do Tigrscan. Para essa tarefa foi necessário uma modificação no código-fonte. Utilizamos a cadeia interpolada de Markov para a região codificadora e não codificadora, e duas combinações de modelos para os sinais: a primeira representando os sinais utilizando a WAM, a segunda representando apenas o sinal doador com a WMM e os demais sinais usando WAM.

\subsection{Resultados}

Inicialmente, fizemos a avaliação dos preditores TigrScan e GlimmerHMM, mostrados na Tabela 6.3. Neste caso, a vantagem do preditor TigrScan é patente, com valores superiores tanto na especificidade quanto na sensibilidade.

Em seguida foram avaliadas as 96 topologias do MYOP. A Tabela 6.4, mostra os 10 modelos de genes com os maiores valores da média entre os valores de especificidade e 
Tabela 6.3: Os preditores Tigrscan e GlimmerHMM foram avaliados com os 65 genes da amostra de teste; $S_{p}$ é a especificidade; $S_{n}$ é a sensibilidade; IMM é cadeia de Markov interpolada; MC é a cadeia de Markov com periodicidade três.

\begin{tabular}{|c|c|c|c|c|c|c|c|c|c|c|c|}
\hline \multirow{2}{*}{ Topologia } & \multirow{2}{*}{$\begin{array}{l}\text { Sensor de } \\
\text { Conteúdo }\end{array}$} & \multicolumn{4}{|c|}{ Sensores de Sinais } & \multicolumn{3}{|c|}{ Éxon } & \multicolumn{3}{|c|}{ Bases } \\
\hline & & iniciação & terminação & aceitador & doador & $S_{n}$ & $S_{p}$ & $\frac{\left(S_{n}+S_{p}\right)}{2}$ & $S_{n}$ & $S_{p}$ & $\frac{\left(S_{n}+S_{p}\right)}{2}$ \\
\hline Tigrscan & IMM & WAM & WAM & WAM & WAM & 56.68 & 66.57 & $\frac{2}{61.63}$ & 92.27 & 88.87 & $\frac{2}{90.57}$ \\
\hline Tigrscan & IMM & WAM & WAM & WAM & WMM & 54.95 & 64.91 & 59.93 & 84.72 & 82.84 & 83.78 \\
\hline GlimmerHMM & IMM & $\begin{array}{l}\text { IMM e } \\
\text { MDD }\end{array}$ & $\begin{array}{l}\text { IMM e } \\
\text { MDD }\end{array}$ & $\begin{array}{l}\text { IMM e } \\
\text { MDD }\end{array}$ & $\begin{array}{l}\text { IMM e } \\
\text { MDD }\end{array}$ & 17.57 & 2.82 & 10.20 & 90.57 & 33.06 & 61.82 \\
\hline
\end{tabular}


sensibilidade no número de bases corretamente preditas. A Tabela 6.5, mostra os 10 modelos de genes com os maiores valores de sensibilidade do número de bases corretamente preditas. Finalmente, a Tabela 6.6 mostra os 10 modelos de genes com os maiores valores de especificidade do número de bases corretamente preditas.

Utilizando essas três tabelas, algumas observações podem ser feitas. Primeiro, apesar da boa exatidão do Tigrscan, o nosso modelo de gene equivalente no MYOP não teve melhores resultados em nehuma ordenação. Segundo, embora o GlimmerHMM utilize um sensor de sinal melhor, a especificidade deste preditor foi menor que qualquer modelo de gene do MYOP. Terceiro, modelos de genes com a topologia do Phat teve um resultado pior em relação aos modelos de genes com a topologia do GlimmerHMM e GeneMark.hmm. Ainda não estudamos a fundo estes dados, mas eles indicam a possibilidade da construção de preditores melhores através do estudo com o MYOP, uma vez incorporadas as heurísticas de predição.

Analisando com mais detalhes algumas características mais específicas pode ser observadas:

- Quando aplicamos o modelo IMM, observamos também um aumento na sensibilidade das bases preditas. Contudo, a cadeia de Markov com periodicidade 3 forneceu um resultado melhor, acertando um número maior de éxons, em relação aos modelos que utilizam IMM.

- Os modelos WMM ou WAM não forneceram mudança significativa para o reconhecimento de sinal de início de tradução ou sinal de fim de tradução. Porém, a utilização do modelo WMM para sítio doador, e o modelo WAM para sítio aceitador resultou em modelos de genes com melhor especificidade e sensibilidade dos éxons preditos.

- A exatidão dos éxons preditos e das bases preditas do Tigrscan caiu significativamente com o modelo WMM no sítio doador, contudo quando utilizamos WMM o Tigrscan acertou a estrutura de um número maior de genes (2 genes a mais).

\subsection{Discussão e Conclusão}

Conseguimos avaliar a exatidão de 96 modelos de genes em apenas dois dias de trabalho. O nosso objetivo não era o de conseguir o melhor modelo de gene, mas queremos mostrar que o sistema fornece um bom ambiente para analisar cada modelo. Este tipo de avaliação é importante, pois, nem sempre um sensor melhor fornece um resultado melhor. WAM pode ser considerada melhor do que uma WMM, porém, WMM melhorou o reconhecimento de éxons nos nossos modelos. 
Tabela 6.4: Exatidão dos modelos. Estamos listando as 10 melhores combinações de acordo com o valor médio entre especificidade e sensibilidade das bases preditas; $S_{n}$ é a sensibilidade; IMM é cadeia de Markov interpolada; MC é a cadeia de Markov com periodicidade três. Nas duas últimas linhas, os dois modelos de genes equivalentes aos modelos de genes do Tigrscan. A tabela completa pode ser obtida em http://www.vision.ime.usp.br/ 〜yoshiaki/MYOP/ myop_validation_Jan_2007.csv

\begin{tabular}{|c|c|c|c|c|c|c|c|c|c|c|c|c|}
\hline & \multirow{2}{*}{ Topologia } & \multirow{2}{*}{$\begin{array}{l}\text { Sensor de } \\
\text { Conteúdo }\end{array}$} & \multicolumn{4}{|c|}{ Sensores de Sinais } & \multicolumn{3}{|c|}{ Éxon } & \multicolumn{3}{|c|}{ Bases } \\
\hline & & & iniciação & terminação & aceitador & doador & $S_{n}$ & $S_{p}$ & $\frac{\left(S_{n}+S_{p}\right)}{2}$ & $S_{n}$ & $S_{p}$ & $\frac{\left(S_{n}+S_{p}\right)}{2}$ \\
\hline 1 & glimmerhmm & $\mathrm{MC}$ & WAM & WAM & WMM & WMM & 10,64 & 18,53 & 14,58 & 78,67 & 92,61 & 85,64 \\
\hline 2 & genemarkhmm & $\mathrm{MC}$ & WAM & WMM & WMM & WMM & 11,14 & 19,40 & 15,27 & 78,04 & 93,04 & 85,54 \\
\hline 3 & genemarkhmm & $\mathrm{MC}$ & WMM & WMM & WMM & WMM & 11,14 & 19,40 & 15,27 & 78,04 & 93,04 & 85,54 \\
\hline 4 & glimmerhmm & $\mathrm{MC}$ & WAM & WMM & WMM & WMM & 10,64 & 18,30 & 14,47 & 78,95 & 92,04 & 85,49 \\
\hline 5 & genemarkhmm & $\mathrm{MC}$ & WAM & WAM & WMM & WMM & 11,63 & 20,43 & 16,03 & 78,05 & 92,70 & 85,37 \\
\hline 6 & genemarkhmm & $\mathrm{MC}$ & WMM & WAM & WMM & WMM & 11,63 & 20,43 & 16,03 & 78,05 & 92,70 & 85,37 \\
\hline 7 & glimmerhmm & $\mathrm{MC}$ & WAM & WAM & WMM & WAM & 7,92 & 13,97 & 10,94 & 77,55 & 92,30 & 84,92 \\
\hline 8 & glimmerhmm & $\mathrm{MC}$ & WMM & WMM & WMM & WMM & 11,39 & 19,41 & 15,40 & 78,44 & 91,36 & 84,90 \\
\hline 9 & glimmerhmm & $\mathrm{MC}$ & WMM & WAM & WMM & WMM & 11,39 & 19,41 & 15,4 & 77,78 & 92,00 & 84,89 \\
\hline 10 & genemarkhmm & $\mathrm{MC}$ & WAM & WMM & WMM & WAM & 8,66 & 15,56 & 12,11 & 76,88 & 92,70 & 84,79 \\
\hline 34 & glimmerhmm & IMM & WAM & WAM & WAM & WMM & 12,62 & 17,23 & 14,92 & 85,67 & 82,57 & 84,12 \\
\hline 68 & glimmerhmm & IMM & WAM & WAM & WAM & WAM & 10,15 & 14,14 & 12,14 & 84,10 & 82,12 & 83,11 \\
\hline
\end{tabular}


Tabela 6.5: Exatidão dos modelos (sensibilidade). Estamos listando as 10 melhores combinações de acordo com a sensibilidade das bases preditas; $S_{n}$ é a sensibilidade; IMM é cadeia de Markov interpolada; MC é a cadeia de Markov com periodicidade três. Nas duas últimas linhas, os dois modelos de genes equivalentes aos modelos de genes do Tigrscan.

\begin{tabular}{|c|c|c|c|c|c|c|c|c|c|c|c|c|}
\hline & \multirow{2}{*}{ Topologia } & \multirow{2}{*}{$\begin{array}{l}\text { Sensor de } \\
\text { Conteúdo }\end{array}$} & \multicolumn{4}{|c|}{ Sensores de Sinais } & \multicolumn{3}{|c|}{ Éxon } & \multicolumn{3}{|c|}{ Bases } \\
\hline & & & iniciação & terminação & aceitador & doador & $S_{n}$ & $S_{p}$ & $\frac{\left(S_{n}+S_{p}\right)}{2}$ & $S_{n}$ & $S_{p}$ & $\frac{\left(S_{n}+S_{p}\right)}{2}$ \\
\hline 1 & glimmerhmm & IMM & WMM & WAM & WMM & WMM & 9,90 & 13,07 & 11,48 & 86,22 & 80,08 & 83,15 \\
\hline 2 & glimmerhmm & IMM & WAM & WAM & WMM & WMM & 9,65 & 12,83 & 11,24 & 86,22 & 80,08 & 83,15 \\
\hline 3 & glimmerhmm & IMM & WMM & WMM & WMM & WMM & 9,90 & 13,29 & 11,59 & 85,83 & 80,13 & 82,98 \\
\hline 4 & glimmerhmm & IMM & WAM & WMM & WMM & WMM & 9,65 & 13,04 & 11,34 & 85,83 & 80,13 & 82,98 \\
\hline 5 & glimmerhmm & IMM & WMM & WAM & WAM & WMM & 12,87 & 17,45 & 15,16 & 85,67 & 82,57 & 84,12 \\
\hline 7 & glimmerhmm & IMM & WMM & WMM & WAM & WMM & 12,13 & 16,90 & 14,51 & 85,29 & 83,09 & 84,19 \\
\hline 8 & glimmerhmm & IMM & WAM & WMM & WAM & WMM & 11,88 & 16,67 & 14,27 & 85,29 & 83,09 & 84,19 \\
\hline 9 & genemarkhmm & IMM & WAM & WMM & WAM & WMM & 12,62 & 17,77 & 15,19 & 85,23 & 83,70 & 84,46 \\
\hline 10 & genemarkhmm & IMM & WMM & WMM & WAM & WMM & 12,62 & 17,77 & 15,19 & 85,23 & 83,70 & 84,46 \\
\hline [6] & glimmerhmm & IMM & WAM & WAM & WAM & WMM & 12,62 & 17,23 & 14,92 & 85,67 & 82,57 & 84,12 \\
\hline 21 & glimmerhmm & IMM & WAM & WAM & WAM & WAM & 10,15 & 14,14 & 12,14 & 84,10 & 82,12 & 83,11 \\
\hline
\end{tabular}


Tabela 6.6: Exatidão dos modelos (especificidade). Estamos listando as 10 melhores combinações de acordo com a especificidade das bases preditas; $S_{n}$ é a sensibilidade; IMM é cadeia de Markov interpolada; MC é a cadeia de Markov com periodicidade três. Nas duas últimas linhas, os dois modelos de genes equivalentes aos modelos de genes do Tigrscan.

\begin{tabular}{|c|c|c|c|c|c|c|c|c|c|c|c|c|}
\hline & \multirow{2}{*}{ Topologia } & \multirow{2}{*}{$\begin{array}{l}\text { Sensor de } \\
\text { Conteúdo }\end{array}$} & \multicolumn{4}{|c|}{ Sensores de Sinais } & \multicolumn{3}{|c|}{ Éxon } & \multicolumn{3}{|c|}{ Bases } \\
\hline & & & iniciação & terminação & aceitador & doador & $S_{n}$ & $S_{p}$ & $\frac{\left(S_{n}+S_{p}\right)}{2}$ & $S_{n}$ & $S_{p}$ & $\frac{\left(S_{n}+S_{p}\right)}{2}$ \\
\hline 1 & genemarkhmm & $\mathrm{MC}$ & WAM & WMM & WAM & WMM & 2,62 & 23,83 & 18,22 & 75,95 & 93,38 & 84,66 \\
\hline 2 & genemarkhmm & MC & WMM & WMM & WAM & WMM & 2,38 & 23,26 & 17,82 & 75,93 & 93,38 & 84,65 \\
\hline 3 & phat & $\mathrm{MC}$ & WAM & WAM & WMM & WMM & 6,93 & 13,66 & 10,29 & 74,21 & 93,35 & 83,78 \\
\hline 4 & phat & $\mathrm{MC}$ & WMM & WAM & WMM & WMM & 6,93 & 13,66 & 10,29 & 74,21 & 93,35 & 83,78 \\
\hline 5 & phat & $\mathrm{MC}$ & WAM & WAM & WAM & WMM & 7,92 & 16,67 & 12,29 & 73,32 & 93,25 & 83,285 \\
\hline 6 & phat & $\mathrm{MC}$ & WMM & WAM & WAM & WMM & 7,92 & 16,67 & 12,29 & 73,32 & 93,25 & 83,28 \\
\hline 7 & genemarkhmm & $\mathrm{MC}$ & WMM & WMM & WAM & WAM & 9,65 & 18,48 & 14,06 & 75,43 & 93,09 & 84,26 \\
\hline 8 & genemarkhmm & $\mathrm{MC}$ & WAM & WMM & WAM & WAM & 9,90 & 18,96 & 14,43 & 75,45 & 93,09 & 84,27 \\
\hline 9 & phat & $\mathrm{MC}$ & WMM & WAM & WMM & WAM & 4,21 & 8,50 & 6,355 & 72,82 & 93,07 & 82,94 \\
\hline 10 & phat & $\mathrm{MC}$ & WAM & WAM & WMM & WAM & 4,21 & 8,50 & 6,355 & 72,82 & 93,07 & 82,94 \\
\hline 70 & glimmerhmm & IMM & $\overline{\text { WAM }}$ & WAM & WAM & WMM & 2,62 & 17,23 & 14,92 & 85,67 & 82,57 & 84,12 \\
\hline 71 & glimmerhmm & IMM & WAM & WAM & WAM & WAM & 0,15 & 14,14 & 12,14 & 84,10 & 82,12 & 83,11 \\
\hline
\end{tabular}


Note que o resultado também depende de como o programa de predição utiliza cada modelo. No caso do Tigrscan, percebemos uma melhora quando utilizamos WAM no sítio doador, em vez de WMM.

Embora o algoritmo de decodificação do GlimmerHMM e do Tigrscan sejam equivalentes [38], observamos uma grande diferença de exatidão entre esses dois preditores. A única diferença entre os dois modelos de genes é que o GlimmerHMM utiliza um sensor de sinal mais sofisticado.

Devemos notar que podemos melhorar a exatidão do GlimmerHMM apenas modificando certos parâmetros estruturais: a distância mínima entre dois genes; um fator penalizador da tendência do preditor dividir os genes; o tamanho médio da região intergênica; um fator que aumenta a sensibilidade dos éxons; um fator que aumenta o escore de "bons" sítios de splicing; um fator que aumenta o número de genes com éxon único; e outros. Cada parâmetro tem grande influência no resultado final. 


\section{Capítulo 7}

\section{Conclusão}

Embora exista um grande número de programas, o problema de predição de genes ainda está longe de ser resolvido [68]. Após a análise de um conjunto de programas com abordagem probabilística percebemos diversas dificuldades: ainda não existe uma comparação justa entre os programas de predição de genes [68]; analisar a influência de cada modelo probabilístico na exatidão das predições implicava na alteração de um programa existente; é difícil implementar diferentes topologias de GHMM, pois ela é descrita no código-fonte em muitos programas; seria necessário implementar cada modelo para possibilitar a utilização de cada um individualmente; finalmente, é difícil de realizar um estudo detalhado dos algoritmos de predição pela ausência de informação mais precisa sobre o resultado das predições de cada modelo da topologia do gene.

O desenvolvimento do sistema MYOP foi motivado por essas dificuldades, uma vez que não existe, tanto quanto pudemos apurar, um sistema onde se pode, ao mesmo tempo estudar cada modelo probabilístico individualmente e também estudar a performance conjunta dos modelos quando utilizados em conjunto dentro de uma GHMM.

A flexibilidade do sistema MYOP nos permite analisar rapidamente um grande número de modelos de genes com arquitetura e modelos diferentes. Como um exemplo de uso, implementamos e avaliamos 96 modelos de genes em apenas dois dias de trabalho. Verificamos que nem sempre um modelo mais sofisticado fornece o melhor preditor, e que as pequenas diferença nas topologias mudaram a exatidão dos programas. Esse fato mostra a importância de experimentar diferentes modelos de gene, já que cada combinação diferente de sensor ou topologia fornece um resultado diferente. É importante ressaltar que mesmo este estudo rápido foi capaz de apresentar melhoras promissoras na performance das topologias de dois preditores de genes largamente utilizados, TigrScan e GlimmerHMM, como mostrado no Capítulo6. A performance dos preditores ainda é melhor do que dos modelos MYOP implementados, mas acreditamos que com a inclusão das heurísticas utilizadas nos preditores reais, estaremos no caminho de produzir melhores 
preditores.

Finalmente, a disponibilidade dos dados em relação a cada sinal e cada gene, nos permitirá entender melhor a performance diferenciada de cada preditor, possivelmente desenvolvendo topologias alternativas que sejam capazes de incorporar vantagens das topologias e modelos utilizados em diferentes programas de predição.

\subsection{Trabalhos futuros}

Este trabalho lançou as bases para o início de um estudo mais aprofundado sobre predição de genes. Nosso objetivo final é o desenvolvimento de novas abordagens que melhorem a performance dos preditores de genes. O próximo passo consiste em estudar em detalhes cada programa de predição, visando entender a diferença de performance entre os modelos "puros" implementados no MYOP e os preditores reais.

Ainda precisamos implementar dois modelos probabilísticos: a cadeia de alcance variável, que permitirá a implementação de um modelo de gene equivalente ao modelo de gene do Phat; e o modelo MDD (maximum dependence decomposition), que permitirá a implementação de um modelo de gene equivalente ao modelo de gene do GlimmerHMM.

Precisamos estudar em detalhes o algoritmo de Viterbi de cada programa, pois existem diferentes implementações desse algoritmo [36, 6, 58]. Podemos observar heurísticas nessas implementações, tal como o uso das seqüências conservadas para o reconhecimento de sinais; fator para alterar a sensibilidade dos éxons; fator penalizador da tendência do preditor dividir cada gene em genes menores; um fator que aumenta o escore de "bons" sítios de splicing; um fator que aumenta o número de éxons únicos preditos. Futuramente, iremos identificar e implementar cada heurística no MYOP. Nossa intenção é introduzir estas heurísticas de forma modular utilizando o padrâo Strategy de desenho orientado a objetos, mas a viabilidade disto ainda precisa ser estudada.

Desenvolver um algoritmo de treinamento que considere os parâmetros estruturais e os aspectos globais pode tanto melhorar a exatidão das predições, quanto deixar a comparação de cada modelo de gene mais uniforme [36]. Atualmente, cada modelo é treinado por máxima verossimilhança usando amostras de regiões locais não levando em consideração os aspectos globais, e existem vários parâmetros estruturais que são ajustados manualmente [36].

Devemos verificar se é possível melhorar a exatidão apenas combinando as diferentes predições de cada modelo de gene, já que, cada modelo fornece evidências diferentes que podem complementar as predições de outros modelos.

No exemplo de uso que vimos, realizamos a validação sobre um único conjunto de 
teste. Seria mais interessante realizar validação cruzada o qual fornece uma estimativa melhor para o erro de generalização dos modelos.

Estudar a combinação da abordagem extrínseca com intrínseca é importante. Um exemplo de sucesso, é o programa Twinscan [29] que utiliza um modelo de gene equivalente ao preditor ab initio Genscan [5], mas ele é capaz de explorar informações extrínsecas entre seqüências conservadas de dois organismos filogeneticamente próximos. Além disso, esse preditor obteve o melhor resultado em relação aos programas que utilizam apenas a abordagem intrínseca numa avaliação entre preditores atuais [28].

Por último gostariamos de ressaltar que, embora o MYOP tenha sido desenvolvido para a implementação de preditores de genes, o fato de que a modelagem do alfabeto de entrada foi feita de maneira modular, permite que o arcabouço orientado a objetos seja utilizado em outros domínios de estudo onde se possa utilizar os modelos probabilísticos aqui utilizados. Para isso seria necessário o desenvolvimento de outros programas de apoio para tarefas como geração de conjunto de treinamentos. 


\section{Referências Bibliográficas}

[1] B. Alberts, D. Bray, J. Lewis, M. Raff, K. Roberts, e J. Watson. Molecular biology of THE CELL. Garland Publishing, 1994.

[2] K. Beck. Simple Smalltalk Testing: With Patterns. Smalltalk Report, 4(2), 1994.

[3] D. A. Benson, I. Karsch-Mizrachi, D. J. Lipman, J. Ostell, e D. L. Wheeler. Genbank. Nucleic Acids Res, 33:D34-D38, Jan 2005.

[4] M. Borodovsky e J. McIninch. Genmark: Parallel gene recognition for both DNA strands. Computer Chem, 17:123-133, 1993.

[5] C. Burge. Identification of genes in human genomic DNA. Tese de Doutoramento, Stanford University, 1997.

[6] C. Burge. Modeling dependencies in pre-mRNA splicing signals. Computational Methods in Molecular Biology, 32:129-164, 1998.

[7] M. Burset e R. Guigò. Evaluation of gene structure prediction programs. Genomics, 34:353-367, Jun 1996.

[8] R. C. Carrasco e J. Oncina. Learning stochastic regular grammars by means of a state merging method. In International Conference on Grammatical Inference, páginas 999-999. Springer-Verlag, setembro 1994.

[9] S. E. Cawley, A. I. Wirth, e T. P. Speed. Phat-a gene finding program for plasmodium falciparum. Mol Biochem Parasitol, 118:167-174, Dec 2001.

[10] J.M. Claverie. Computational methods for the identification of genes in vertebrate genomic sequences. Human Molecular Genetics, 6:1735-1744.

[11] F. Crick. Central dogma of molecular biology. Nature, 227(5258):561-563, 1970.

[12] F. H. C. Crick. The genetic code III. Sci Am, 215:55-55, Oct 1966.

[13] S. Dong e D. B. Searls. Gene structure prediction by linguistic methods. Genomics, 23:540-551, Oct 1994. 
[14] R. O. Duda, P. E. Hart, e D. G. Stork. Pattern Classification (2nd Edtion). Wiley Interscience Publication, 2001.

[15] P. Dupont, L. Miclet, e E. Vidal. What is the search space of the regular inference? In ICGI: International Colloquium on Grammatical Inference and Applications. 1994.

[16] R. Durbin, S. R. Eddy, A. Krogh, e G. Mitchison. Biological sequence analysis: Probabilistic models of proteins and nucleic acids. The press syndicate of the University of Cambridge, 1998.

[17] P. A. Ferrari e J. A. Galves. Acoplamento e processos estocásticos. Colóquio Brasileiro de Matemática, Rio de Janeiro, 1997.

[18] J. Fickett e C. S. Tung. Assessment of protein coding measure. Nucleic Acids Res, 20:6441-6450, 1992.

[19] J. W. Fickett. Recognition of protein coding regions in dna sequences. Nucleic Acids Res, 10:5303-5318, Sep 1982.

[20] E. Gamma, R. Helm, R. Johnson, e J. Vlissides. Design Patterns: Elements of Reusable Object-Oriented Software. Addison Wesley, Massachusetts, 1994.

[21] Y. Guédon. Estimating hidden semi-Markov chains from discrete sequences. Journal of Computational and Graphical Statistics, 12(3):604-??, setembro 2003.

[22] S. A. Hamed e E. P. Hoffman. Automated sequence screening of the entire dystrophin cDNA in duchenne dystrophy: point mutation detection. Am J Med Genet B Neuropsychiatr Genet, 141:44-44, Jan 2006.

[23] Huang, Li, Chen, e Wu. An approach of encoding for prediction of splice sites using svm. Biochimie, Apr 2006. ISSN 0300-9084.

[24] G. B. Hutchinson e M. R. Hayden. The prediction of exons through an analysis of spliceable open reading frames. Nucleic Acids Res, 20:3453-3462, Jul 1992.

[25] A. Y. Kashiwabara e A. M. Durham. Biological signal prediction using stochastic regular grammars. Poster - Intelligent Systems for Molecular Biology (ISMB) Fortaleza, Brasil, August 2006.

[26] A. Y. Kashiwabara, D. Vieira, A. Machado-Lima, e A. M. Durham. Splice site prediction using grammar inference. Genetics and Molecular Research, 2007.

[27] E. Keibler e M.R. Brent. Eval: A software package for analysis of genome annotations. feedback, 2004. 
[28] K. Knapp e Y.-P. P. Chen. An evaluation of contemporary hidden markov model genefinders with a predicted exon taxonomy. Nucleic Acids Res, Dec 2006. ISSN 1362-4962.

[29] I. Korf, P. Flicek, D. Duan, e M.R. Brent. Integrating genomic homology into gene structure prediction. Bioinformatics, 17(Suppl 1):S140-S148, 2001.

[30] A. Krogh. Two methods for improving performance of an HMM and their application for gene finding. In In Proc. Fifth Int. Conf. Intelligent System for Molecular Biology, páginas 179-186. 1997.

[31] A. Krogh. An introduction to hidden markov models for biological sequences. Computational Methods in Molecular Biology, 32:45-63, 1998.

[32] D. Kulp., D. Haussler., M. G. Reese., e F. H. Eeckman. A generalized hidden Markov model for the recognition of human genes in DNA. Proc Int Conf Intell Syst Mol Biol, 4:134-142, 1996.

[33] A. Lomsadze, V. Ter-Hovhannisyan, Y. O. Chernoff, e M. Borodovsky. Gene identification in novel eukaryotic genomes by self-training algorithm. Nucleic Acids Res, 33:6494-6506, November 2005.

[34] W. H. Majoros, M. Pertea, e S. Salzberg. TigrScan and GlimmerHMM: two open source ab initio eukaryotic gene-finders. Bioinformatics, 20:2878-2879, Nov 2004.

[35] W. H. Majoros, M. Pertea, e S. L. Salzberg. Efficient implementation of a generalized pair hidden markov model for comparative gene finding. Bioinformatics, 21:1782-1788, May 2005.

[36] W. H. Majoros e S. L. Salzberg. An empirical analysis of training protocols for probabilistic gene finders. BMC Bioinformatics, 5:206, December 2004.

[37] W.H. Majoros, M. Pertea, C. Antonescu, e S.L. Salzberg. GlimmerM, Exonomy and Unveil: three ab initio eukaryotic genefinders. Nucleic Acids Research, 31(13):3601-3604, 2003.

[38] W.H. Majoros, M. Pertea, A.L. Delcher, e S.L. Salzberg. Efficient decoding algorithms for generalized hidden Markov model gene finders. BMC Bioinformatics, 6(1):16, 2005.

[39] C. Mathé, M. F. Sagot, T. Schiex, e P. Rouzé. Current methods of gene prediction, their strengths and weaknesses. Nucleic Acid Rese, 30:4103-4117, 2000.

[40] D. W. Mount. Bioinformatics - Sequence and Genome Analysis. Cold Spring Harbor Laboratory Press, Cold Spring Harbor, NY, 2001. 
[41] K. Munch e A. Krogh. Automatic generation of gene finders for eukaryotic species. BMC Bioinformatics, 7:263, May 2006.

[42] G. Parra, E. Blanco, e R. Guigò. Geneid in drosophila. Genome Res, 10:511-515, Apr 2000.

[43] N. Pavy, S. Rombauts, P. Déhais, C. Mathé, D. V. Ramana, P. Leroy, e P. Rouzé. Evaluation of gene prediction software using a genomic data set: application to arabidopsis thaliana sequences. Bioinformatics, 15:887-899, Nov 1999. ISSN 13674803.

[44] M. Pertea, X. Lin, e S. Salzberg. GeneSplicer: a new computational method for splice site prediction. Nucleic Acids Res, 29:1185-1190, Mar 2001.

[45] L. R. Rabiner. A tutorial on Hidden Markov Models and selected applications in speech recoginition. In Proccedings of the IEEE, volume 77, páginas 257-286. February 1989.

[46] M. G. Reese e F. H. Eeckman. Improved splice site detection in Genie. J Comp Biol, 4:311-323, 1997.

[47] A. Rich e S. H. Kim. The three-dimensional structure of transfer RNA. Sci Am, 238:52-52, Jan 1978.

[48] S. Rogic, A. K. Mackworth, e F. B. Ouellette. Evaluation of gene-finding programs on mammalian sequences. Genome Res, 11:817-832, May 2001.

[49] D. Ron, Y. Singer, e N. Tishby. The power of amnesia: Learning probabilistic automata with variable memory length. Machine Learning, 25:117, 1996.

[50] D. Ron, Y. Singer, e N. Tishby. On the learnability and usage of acyclic probabilistic finite automata. JCSS: Journal of Computer and System Sciences, 56, 1998.

[51] S.M. Ross. Simulation. Morgan Kaufmann Publishers Inc. San Francisco, CA, USA, 1996.

[52] S. Rudd. Expressed sequence tags: alternative or complement to whole genome sequences? Trends Plant Sci, 8:321-329, Jul 2003. ISSN 1360-1385.

[53] S. Salzberg, A. L. Delcher, S. Kasif, e O. White. Microbial gene identification using Interpolated Markov Models. Nucleic Acids Research, 26:544-548, 1998.

[54] S. Salzberg, M. Pertea, A. Delcher, M. J. Gardner, e H. Tettelin. Interpolated Markov models for eukaryotic gene finding. Genomics, 59:24-24, Jul 1999.

[55] S.J. Sheather. Density estimation. Statistical Science, 19(4):588-597, 2004. 
[56] V.V. Solovyev, A.A. Salamov, e C.B. Lawrence CB. Predicting internal exons by oligonucleotide composition and discriminant analysis of spliceable Open Reading Frames. Nucleic Acids Res, 22:5156-5163, 1994.

[57] R. Staden. Computer methods to locate signals in nucleic acid sequences. Nucleic Acids Res, 12:505-519, 1984.

[58] M. Stanke. Gene prediction with a hidden Markov model. Tese de Doutoramento, Universität Göttingen, 2003.

[59] M. Stanke e S. Waack. Gene prediction with a hidden Markov model and a new intron submodel. Bioinformatics, 19 Suppl 2:II215-II215, Oct 2003.

[60] T. A. Thanaraj. Positional characterisation of false positives from computational prediction of human splice sites. Nucleic Acids Res, 28:744-754, Feb 2000. ISSN 1362-4962.

[61] A. Thomas e M. H. Skolnick. A probabilistic model for detecting coding regions in dna sequences. IMA J Math Appl Med Biol, 11:149-160, 1994.

[62] Vapnik. Statistical Learning Theory. John Wiley, setembro 1998.

[63] E. Vidal, F. Thollard, C. de la Higuera, F. Casacuberta, e R. C. Carrasco. Probabilistic finite-state machines-part I. IEEETPAMI: IEEE Transactions on Pattern Analysis and Machine Intelligence, 27, 2005.

[64] Z. Wang, Y. Chen, e Y. Li. A brief review of computational gene prediction methods. Genomics Proteomics Bioinformatics, 2:216-221, Nov 2004.

[65] A. I. Wirth. A Plasmodium falciparum genefinder. Honours research project. Department of Mathematics and Statistics. University of Melbourne, Parkville VIC.

[66] Y. Xu e E. C. Uberbacher. Computational gene prediction using neural networks and similarity search. Computational Methods in Molecular Biology, 32:109-128, 1998.

[67] G. Yeo e Christopher B. Maximum entropy modeling of short sequence motifs with applications to rna splicing signals. J Comput Biol, 11:377-394, 2004.

[68] M. Q. Zhang. Computational prediction of eukaryotic protein-coding genes. Nat Rev Genet, 3:698-698, Sep 2002.

[69] M. Q. Zhang e T. G. Marr. A weight array method for splicing signal analysis. Computer Applied in Bioscience, 9:499—509, 1993. 
[70] MQ Zhang. Identification of protein coding regions in the human genome by quadratic discriminant analysis, 1997.

[71] W. Zucchini e I.L. MacDonald. Hidden Markov and Other Models for DiscreteValued Time Series. CRC Press, 1997. 


\section{Apêndice A}

\section{Utilizando o MYOP}

\section{A.1 Programabuild_model}

Para construir qualquer modelo, precisamos utilizar o programa build_model. Esse programa tem dois parâmetros obrigatórios: o tipo de modelo a ser construído; e o nome do modelo de saída. Os outros parâmetros são específicos de cada modelo e do algoritmo de construção que é utilizado: podemos construir uma cadeia de Markov usando um algoritmo de treinamento; ou a partir de um arquivo descrevendo cada estado e cada transição.

O treinamento necessita de um conjunto de seqüências de genes anotados. Geralmente, essas sequiências estão em arquivos no formato FASTA, e as anotações estão em arquivos no formato GFF ${ }^{1}$ (general feature format). A partir desses dois arquivos, extraímos as amostras e obtemos outros arquivos FASTAs contendo sequiências de cada tipo de região do gene: éxon; íntron; região intergênica; região codificadora; os sinais biológicos; e falsos sinais. Para extrair as seqüências de cada tipo de região podemos utilizar o programa seqparser do MYOP, ele recebe uma tabela especificando a localização de cada região e devolve arquivos FASTAs contendo as seqüências dessas regiões.

\section{A.2 Gerando seqüências simuladas}

As sequiências podem ser geradas por simulação usando o programa generate_sequence. Ele recebe a saída obtida pelo programa build_model e devolve um arquivo no formato FASTA. O usuário deve especificar a quantidade e o tamanho das seqüências geradas.

\footnotetext{
${ }^{1} \mathrm{O}$ formato GFF especifica uma tabela que tem a localização exata de cada região do gene.
} 


\section{A.3 Configurando uma GHMM}

Suponha que temos um conjunto de modelos representando cada região do gene, e agora queremos construir um preditor de genes. Para essa tarefa, uma GHMM deve ser configurada manualmente: devemos especificar os modelos; os sensores; a configuração de cada estado; e as transições do estado.

\section{Especificando os modelos utilizados}

A primeira tarefa da construção de uma GHMM é a de especificar quais modelos serão utilizados. Um arquivo de configuração ${ }^{2}$ (“model.cnf”) contendo cada modelo e um apelido deve ser editado:

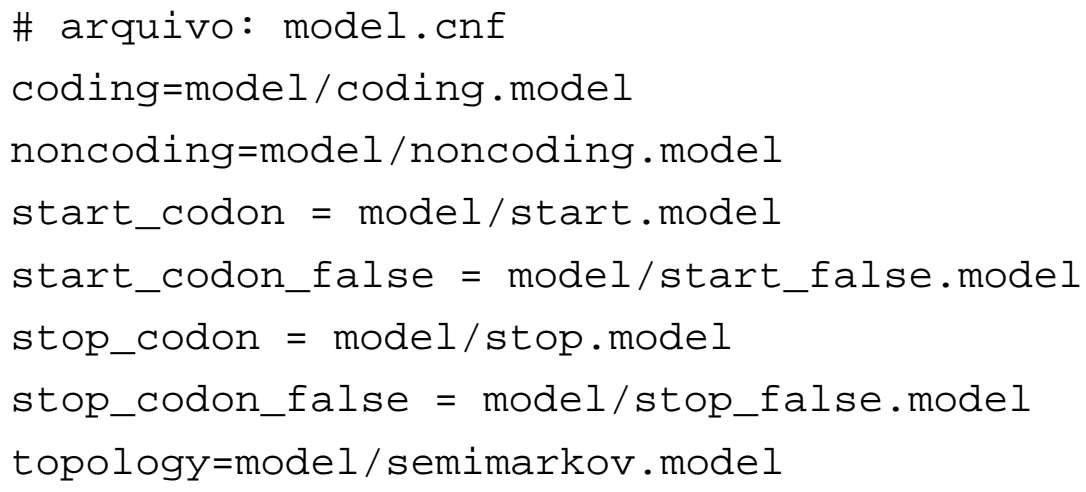

Neste exemplo, estamos especificando 4 modelos com apelidos: coding, noncoding, start_codon, stop_codon, start_codon_false, e stop_codon_false. O parâmetro "topology" é obrigatório e define a topologia da GHMM. A topologia é uma cadeia semi-markoviana que é formada por uma cadeia de Markov em que cada estado tem uma distribuição de duração fornecida de forma explícita. A Figura A.1 mostra a topologia da GHMM que estamos configurando, um preditor desse tipo funciona como um achador de ORF para procarioto. Estamos modelando apenas dois estados: a região codificadora e a região intergênica.

Figura A.1: Uma topologia simples com apenas dois estados: N, região intergênica; coding, região codificadora

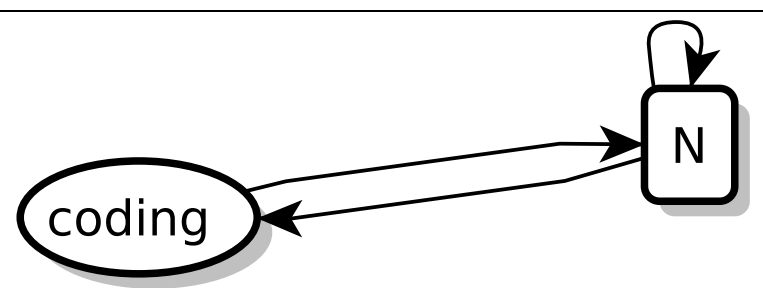

\footnotetext{
${ }^{2} \mathrm{O}$ usuário define o nome de cada arquivo de configuração.
} 


\section{Definindo os sensores de sinais}

Devemos configurar cada sensor de sinal, o arquivo ("signal.cnf") especifica o nome do sensor de sinal:

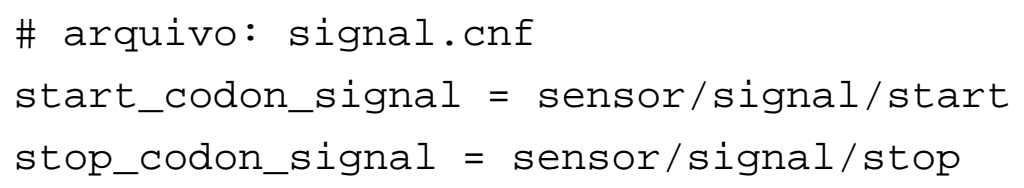

Estamos configurando dois sensores de sinais: um para o sítio de início de tradução; e outro para o sítio de fim de tradução. O arquivo "sensor/signal/start" serve para especificar os parâmetros do sensor "start_codon_signal":

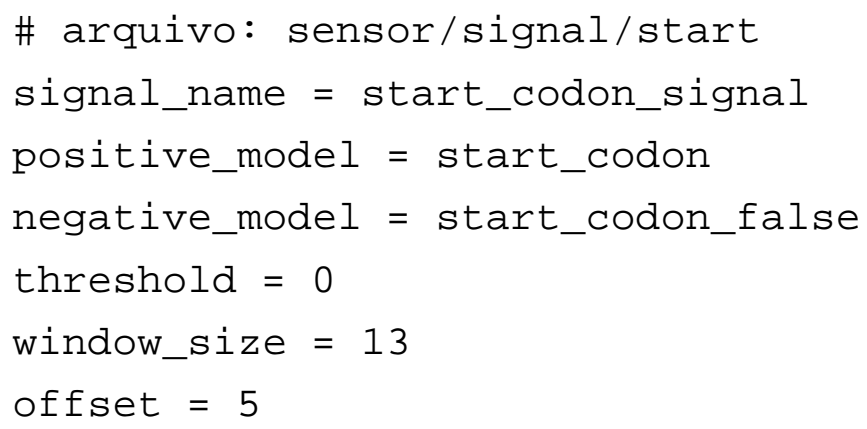

Um sensor de sinal serve para separar duas regiões de tipos diferentes de tamanho variável: o valor de "offset" serve para indicar a primeira posição da próxima região. Neste caso, a próxima região é a região codificadora, que começa na posição 5 da janela, sendo que a seqüência da janela começa na posição 0 .

\section{Definindo os sensores de conteúdo}

O próximo passo consiste em especificar quais sensores de conteúdo serão utilizados. No arquivo (“content.cnf”), estamos configurando dois sensores de conteúdo. O primeiro para o reconhecimento de regiões codificadoras, e o segundo para o reconhecimento de regiões não codificadoras.

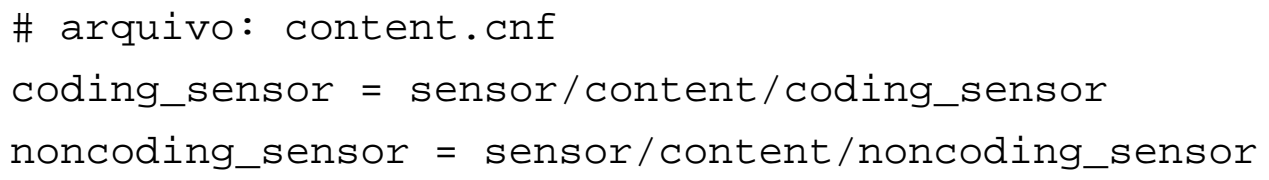

O arquivo "sensor/content/coding_sensor" serve para configurar o sensor de conteúdo “coding_sensor": 
\# arquivo: sensor/content/coding_sensor

content_sensor_name = coding_sensor

positive_model = coding

negative_model = noncoding

O sensor de conteúdo "coding_sensor" é definido por um modelo positivo ("coding”) e um modelo negativo ("noncoding").

\section{Configurando os estados}

A topologia que estamos modelando possuem dois estados que também devem ser configurados:

\# arquivo: state.cnf

$\mathrm{N}=$ state $/ \mathrm{N}$

coding $=$ state/coding

Para cada estado temos um arquivo de configuração:

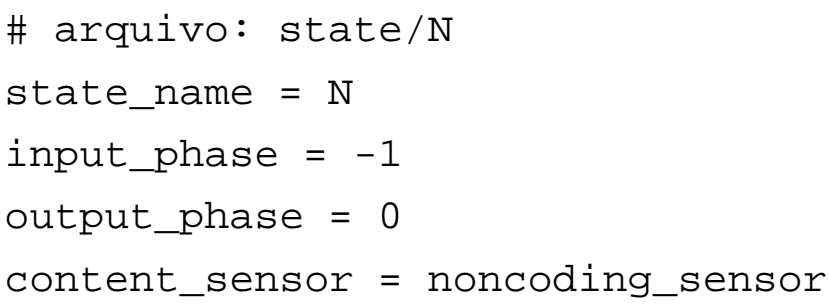

Estamos indicando que a fase de saída do estado $N$ é a fase 0 , e a fase de entrada é livre: quando o valor da fase é negativa então a fase pode ser qualquer um.

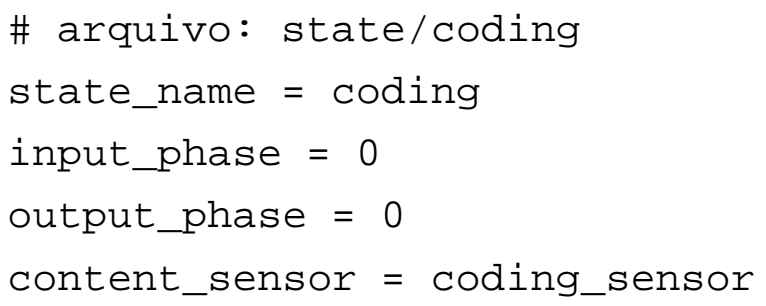

A região codificadora entra com a fase de leitura zero e saí com a fase zero, isto garante que o tamanho da região codificadora seja múltiplo de três. 


\section{Configurando as transições}

Como os sensores de sinais definem a fronteira de duas regiões, para cada transição está associado um sensor de sinal:

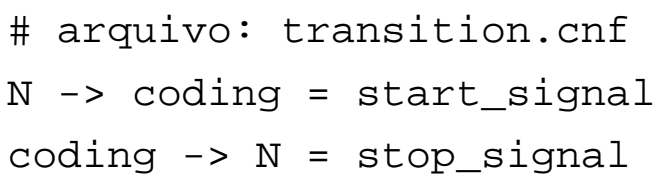

Enquanto a transição da região intergênica para a região codificadora tem um sinal de início de tradução, a transição da região codificadora para a região intergênica tem um sinal de fim de tradução.

\section{Juntando todas as configurações}

Finalmente, o arquivo principal ("ghmm.cnf”) pode ser construído. Ele simplesmente tem a localização de cada uma das configurações: modelos, sensor de sinal, sensor de conteúdo, estados, e transições:

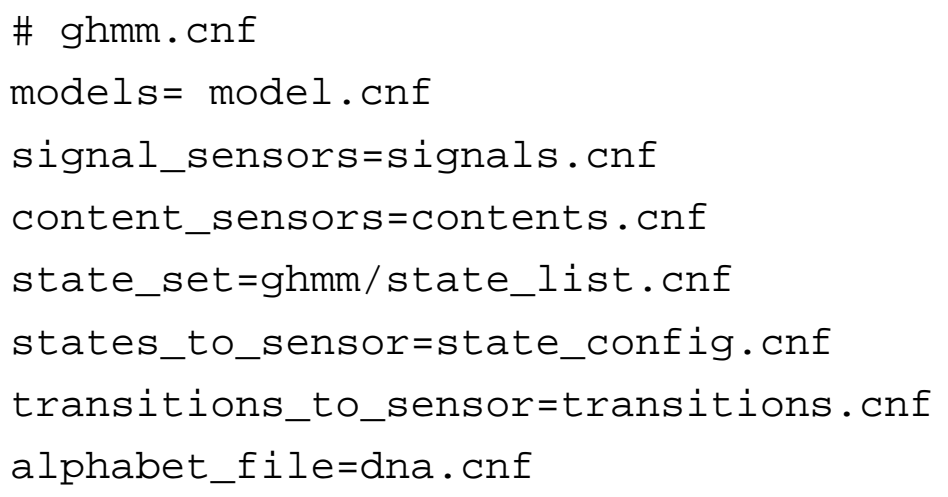

O parâmetro "state_set" indica a lista dos estados utilizados, e o parâmetro "alphabet_file" é simplesmente uma lista com símbolos da alfabeto que estamos utilizando.

\section{A.4 Encontrando a estrutura do gene}

Para procurar o caminho mais provável na GHMM, podemos utilizar o programa gene_predictor. Ele recebe o arquivo principal de configuração da GHMM e um arquivo FASTA e devolve para cada seqüência uma possível estrutura do gene. 


\section{A.5 Outros programas do MYOP}

- $c d s \_f i n d e r$ fornece um escore para cada ponto da seqüência indicando a possibilidade dele ser codificador;

- score_sequence recebe um modelo positivo e um modelo negativo e devolve o escore log-odds para cada seqüência de um arquivo no formato FASTA;

- smoothed_distribution recebe um conjunto de sequiência e devolve uma distribuição suavizada do comprimento das sequiências do conjunto de entrada; 


\section{Apêndice B}

\section{Gerando seqüências por simulação dos modelos}

\section{Cadeia de Markov}

O seguinte algoritmo serve para gerar uma seqüência de tamanho $N$ usando a simulação da cadeia de Markov. O valor de distribuicao[e] é um objeto FiniteDiscreteDistribution que indica a probabilidade de um símbolo no estado $e$. A cada passo do algoritmo, um novo símbolo é escolhido, e o estado atual é atualizado. No final, o algoritmo devolve o vetor de símbolos $X$

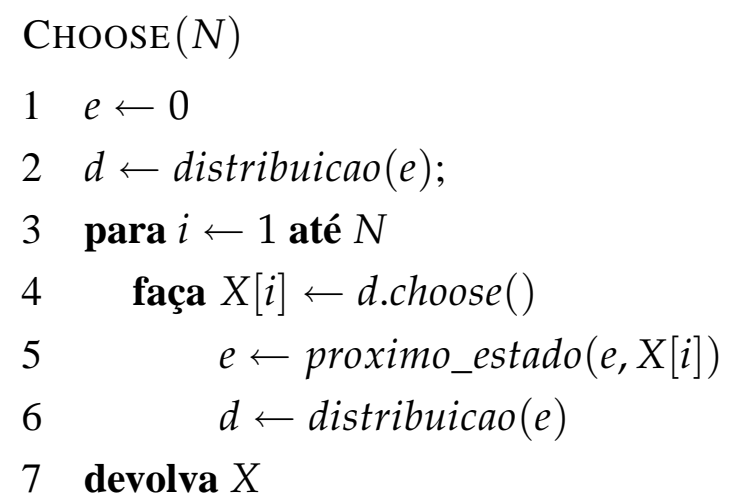

\section{Weight array method}

Na simulação de uma WAM, a cada posição $i$ uma cadeia de Markov diferente é utilizada (markov[i]). O método choose_next_symbol da MarkovChain recebe um histórico $X_{1}, X_{2}, \ldots, X_{i-1}$, e escolhe ao acaso o próximo símbolo. O valor de max_wam_size indica qual é o tamanho máximo das palavras geradas pelo modelo. 


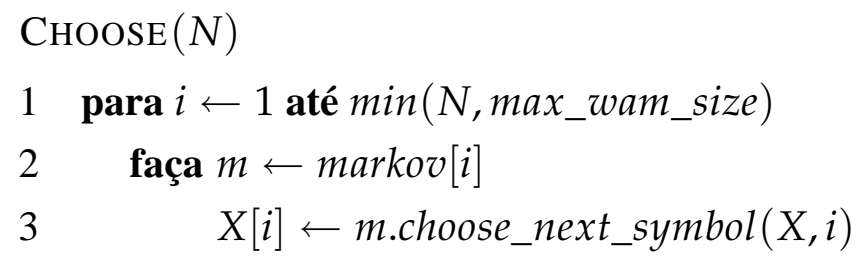

4 devolva $X$

\section{Cadeia de periodicidade três de Markov}

Neste algoritmo, a cada fase de leitura existe uma cadeia de Markov, markov[fase] ( fase $\in\{0,1,2\}$ ). A cada passo um novo símbolo é sorteado, e a fase é atualizada. $\mathrm{O}$ algoritmo termina quando uma sequiência de símbolos de tamanho $N$ foi gerada.

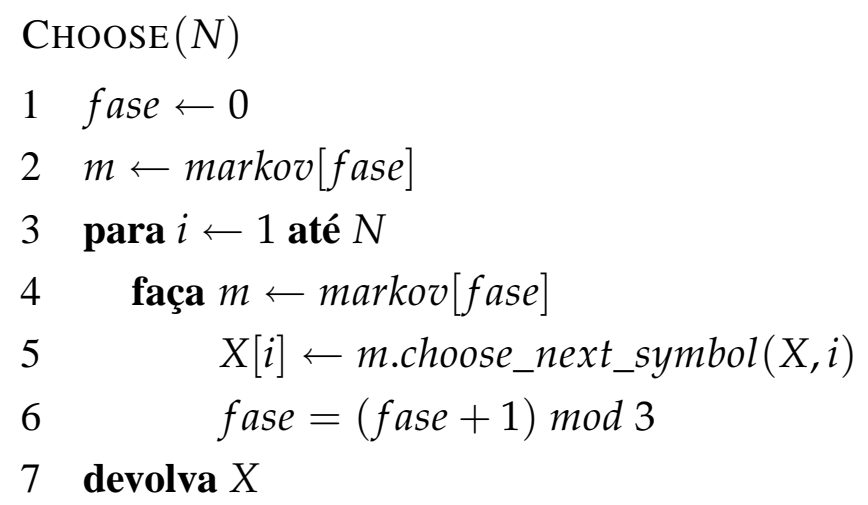

\section{Cadeia semi-markoviana}

Na linha 3 do próximo algoritmo, um novo símbolo dado o histórico $X_{1}, \ldots, X_{i-1}$ é sorteado. Na linha 4, o estado atual é computado. Na linha 6 , uma duração $d(d \geq 1)$ é sorteada a partir da distribuição de probabilidade da duração do estado $e$. Na iteração das linhas $8-10$, o algoritmo preenche o vetor a partir do elemento $X[i+1]$ até $X[d+i-1]$ com o valor de $X[i]$. O algoritmo devolve o vetor $X$ de símbolos. 


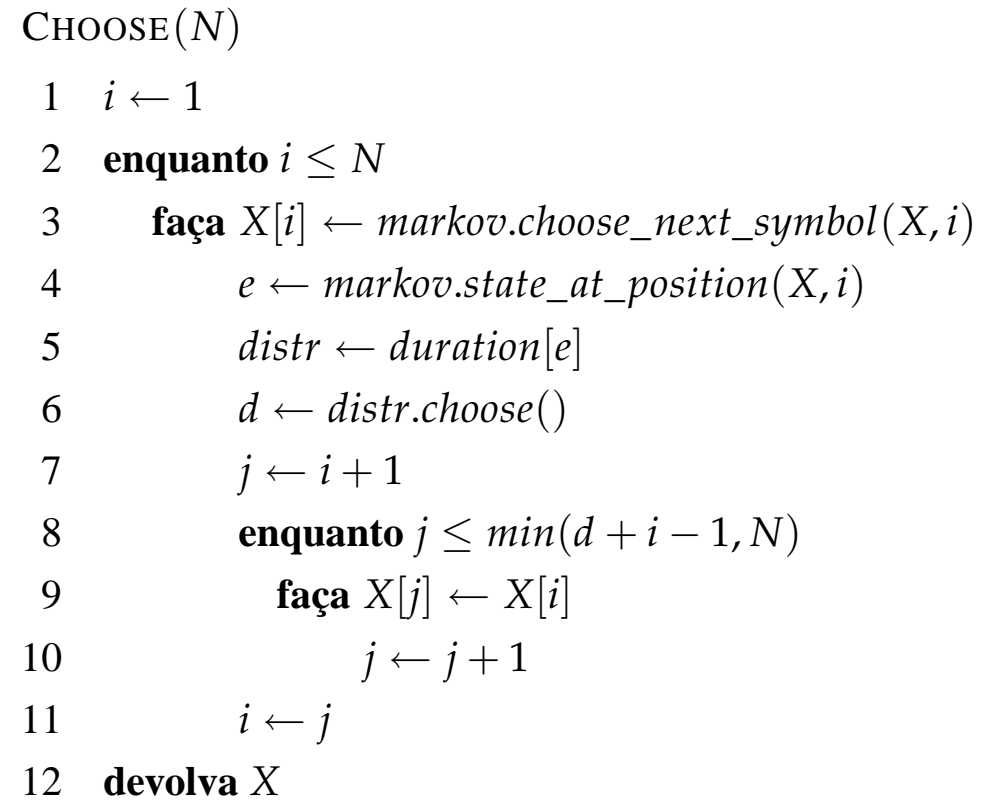

\section{Cadeia oculta de Markov}

Na primeira linha, o algoritmo escolhe um estado: a cadeia de Markov neste caso é de ordem 1, assim o símbolo corresponde ao estado da cadeia. Na linha 3, um símbolo é emitido a partir da probabilidade de emissão dada pelo objeto do tipo FiniteDiscreteDistribution associado ao estado $e$. A iteração das linhas 5-8 consiste em sortear o próximo estado, e de emitir um próximo símbolo. O algoritmo devolve o vetor de símbolos $X$. Repare que a cadeia de Markov permanece oculta.

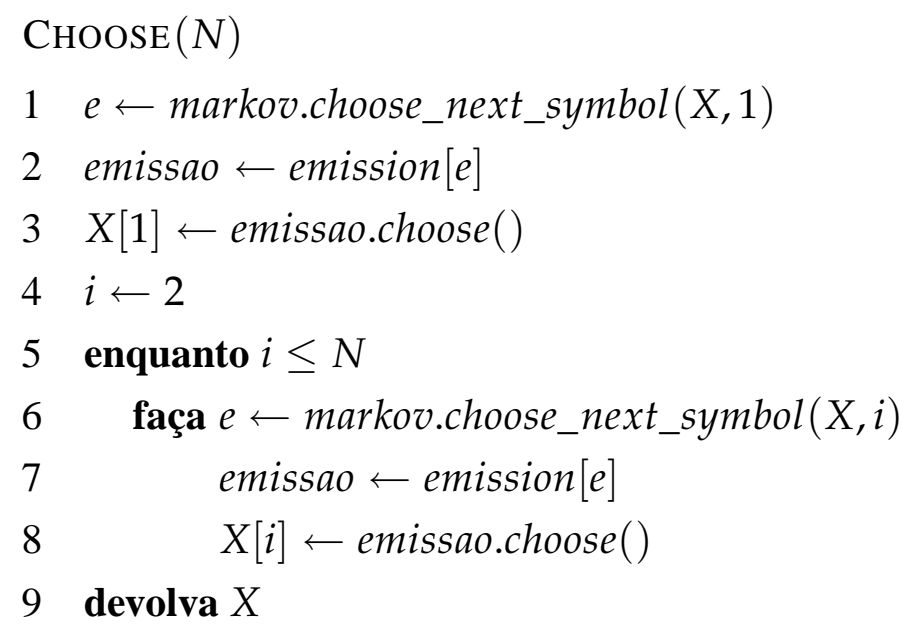

\section{Cadeia oculta generalizada de Markov}

Para gerar uma seqüência usando a cadeia oculta generalizada de Markov, primeiro é sorteado um caminho $S[1 . . N]$ : o último elemento, $S[N+1]$, é o estado nulo diferente 
de qualquer estado que pode ser gerado pelo processo semi-markoviano. Percorrendo o caminho gerado $S$, podemos descobrir a duração $d$ de cada estado. A medida que ocorre uma mudança de estado é emitido uma palavra de tamanho $d$. Este algoritmo devolve uma seqüência $X$ de símbolos.

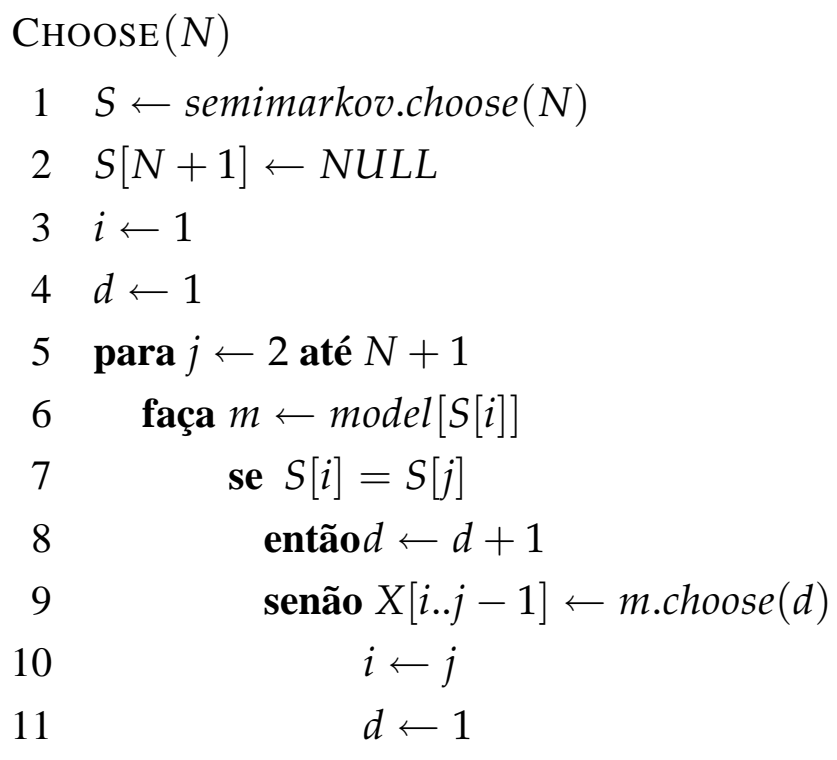

\section{2 devolva $X$}




\section{Apêndice C}

\section{Avaliação entre preditores de genes}

\section{C.1 Medidas de exatidão da predição de genes}

Podemos fazer uma análise comparativa com o método descrito em [28, 7, 43]. Basicamente, analisamos a exatidão da predição em três pontos de vista: bases codificadoras, estrutura exônica, e produtos protéicos.

No ponto de vista de bases codificadoras, é tradicionalmente observada a exatidão da predição sobre o conjunto de teste comparando o valor de predição codificadora (codificadora ou não-codificadora) com o valor real de cada base da sequiência. Assumimos que tanto a predição quanto o valor real é dado por variáveis binárias cujo o valor (codificadora ou não-codificadora) é observado ao longo das bases da seqüência.

Utilizamos quatro contagens: (1) TP é a quantidade de bases codificadoras que foram corretamente preditas como codificadoras; (2) TN é a quantidade de bases nãocodificadoras que foram corretamente preditas como não-codificadoras; (3) FN é a quantidade de bases codificadoras que foram preditas como não-codificadoras; (4) FP é a quantidade de bases não-codificadoras que foram preditas como codificadoras $(F P)$.

As duas medidas que podem ser obtidas usando essas contagens são a sensibilidade $\left(S_{n}\right)$ e a valor de predição positiva $\left(S_{p}\right)$ definidas como:

$$
\begin{aligned}
& S_{p}=\frac{T P}{T P+F P} \\
& S_{n}=\frac{T P}{T P+F N}
\end{aligned}
$$

Devemos observar que na literatura sobre predição de genes, o valor de predição positiva é também chamado de especificidade [7, 48].

Contudo, cada um desses valores de exatidão não fornece sozinho uma medida global. 
Nesse caso, podemos utilizar o coeficiente de correlação (CC), dado por:

$$
C C=\frac{(T P \times T N)-(F N \times F P)}{\sqrt{(T P+F N) \times(T N+F P) \times(T P+F P) \times(T N+F N)}}
$$

Esta medida fornece a idéia global de exatidão e pode ser aplicada como a função objetiva durante o treinamento dos programas de predição de genes.

No ponto de vista de éxons, é utilizado um conjunto de quatro medidas de exatidão: sensibilidade $\left(S_{n}\right)$, especificidade $\left(S_{p}\right)$, éxon perdidos $(M E)$, e éxons errados $(W E)$.

$$
\begin{aligned}
S_{n} & =\frac{\text { Número de éxons corretos }}{\text { Número de éxons reais }} \\
S_{p} & =\frac{\text { Número de éxons corretos }}{\text { Número de éxons preditos }} \\
M E & =\frac{\text { Número de éxons perdidos }}{\text { Número de éxons reais }} \\
W E & =\frac{\text { Número de éxons errados }}{\text { Número de éxons preditos }}
\end{aligned}
$$

Um éxon foi perdido se nenhuma base real deste éxon foi predito. E um éxon é considerado errado se alguma base do éxon não foi predito corretamente.

No ponto de vista de produtos preditos, contamos a total relativo dos genes nas quais todos os éxons foram preditos corretamente. 


\section{Apêndice D}

\section{Poster ISMB 2006}

Poster apresentado no International Conference On Intelligent Systems for Molecular Biology em Agosto de 2006 que ocorreu em Fortaleza, Brasil.

\section{Biological signal prediction using Stochastic Regular Gram- $\operatorname{mar}[25]$}

\section{Authors}

Andre Kashiwabara (IME-USP)

Alan Durham (IME-USP)

\section{Short Abstract}

Two technologies have been widely applied for ab initio splice site prediction, WMM and WAMs. We show that WMMs and WAMs are part of the search space of inference algoritms for Sochastic Regular Grammars and present an algorithm that converge to any of them.

\section{Long Abstract}

Biological signal prediction by computational methods is an important step for an accurate ab initio gene prediction. In particular, splice site prediction is a difficult and relevant problem. Weight Matrix Method (WMM) [57] and Inhomogeneous Markov Model (IHMM 
or WAM) [69] are two signal sensors that were incorporated in ab initio gene prediction, and are widely used in splice site prediction methods $[31,59,44,5]$.

In the last two decades, various pattern recognition methods were applied in splice site prediction and some of them uses WMM or IHMM, such as decision trees, and Support Vector Machines (SVM) [62]. Maximum Dependence Decomposition [6] is a decision tree approach that makes a partition of the dataset such that the strongest dependencies are captured at the earliest branch points, and WMM or IHMM can be used to represent each subset of the tree. SVM has been employed recently, and it also have applied WMM for feature extraction [23].

Probabilistic Finite Automata (PFA) is a syntactic object which can model and generate the same probability distribution as Hidden Markov Models (HMM) [31] over sets of strings [63]. Deterministic PFA (DPFA) are not as powerful as HMMs, but some problems become tractable: (1) DPFA has a simple and efficient recognizer (called parser ) with complexity $O(n)$, where $\mathrm{n}$ is the size of the word. (2) DPFA equivalence problem is tractable, because it admits a minimal object. In a previous work, we have shown that a DPFA has a similar performance than NNSPLICE [46] for donor site prediction [26].

In our current work, we show that WMM and IHMM are particular cases of Deterministic Probabilistic Finite Automata (DPFA), and that both signal sensors are in the search space of DPFA inference algorithms that employ prefix tree automata: Learn Acyclic PFA (LAPFA) [50] and ALERGIA [8]. These algorithms work over a search space that can be viewed as a lattice in which the elements are the automatas. The canonical automata of this lattice is the prefix tree automata that recognizes only the training set, and the universal automata has only one state with recursive transitions for every entry symbol, recognizing any string over the alphabet. The DPFA interence algorithms mentioned above modify the prefix tree automata interactively by merging different states. This creates a search space of automata that can be reached from the prefix tree automata by successive state merging operations [15]. The idea is to search an automata that is a good approximation of a target probabilistic automata.

In spite of IHMMs being in the theoretical search space of the LAPFA algorithm, experiments with splice site prediction have shown us that even the best parameter setting of the algorithm was converging to a DPFA similar to a WMM, in spite of the fact that IHMM presented better prediction performance. We have thus developed a modification of LAPFA that enables it to also converge also to IHMMs, if the training sample supports this convergence.

DPFA could be a good alternative to IHMM and WMM, but more investigation must to be done, in particular trying to find better convergence points in the specific case of splice sites. 
In this work we present the proof that IHMM and WMM have equivalent DPFAs, the proof that the DPFAs are in the theoretical search space of prefix-tree-based DPFA inference algorithms, and an extension of the LAPFA inference algorithm, that ensures it can also converge IHMM-equivalent DPFAs. Finally, we show the comparative results of the new DPFA inference algorithm on splice site prediction against WMMs and IHMMs. Future work includes a study of other modifications on the LAPFA algorithm aiming at improving the performance of DPFAs on splice site prediction in particular and signal prediction in general. 


\section{Índice Remissivo}

analisador, 13

anticódon, 8

códon, 8

de iniciação, 8

de terminação, 8

comprimento da memória, veja ordem, 35

decodificador, 13

estimador de densidade pela função núcleo,

20

estrutura do gene

éxon, 10, 13

único, 18

final, 18

inicial, 18

interno, 18

íntron, 10, 13, 18

promotor, 6

região 3' não traduzida, 10, 19

região 5' não traduzida, 10, 19

região intergênica, 9, 13, 18

sítio de fim de tradução, 9

sítio de fim de transcrição, 6

sítio de início de tradução, 9

sítio de início de transcrição, 6

fase de leitura, $8,16,17,22$

função logística, 16

inferência gramatical

LAPFA, 15

janela deslizante, 17 modelo de genes, 18

modelo probabilístico, 29

cadeia de Markov, 16, 29

definição, 31

homogênea, 22, 31

IMM, 18

matriz de transição, 31

não homogênea, 31

cadeia de Markov com periodicidade três,

$16,18,22$

definição, 34

cadeia oculta generalizada de Markov,

18,22

algoritmo de Viterbi, 42, 43

algoritmo forward, 42

definição, 41

distribuição da duração, 20

emissão, 18

estado com duração explícita, 18

estado com duração geométrica, 18

estados, 18

probabilidade de emissão, 19, 42

topologia, 19

transição de estados, 18

cadeia oculta de Markov, 18

algoritmo de Viterbi, 39

algoritmo forward, 39

definição, 38

interpolated Markov model, 16, 22

WAM, 15, 22

definição, 33

e gramáticas, 15

probabilidade de emissão, 33 
WMM, 14, 22

definição, 32

e gramáticas, 15

limitação, 15

probabilidade de emissão, 33

ordem, 15,16

open reading frames, 16

organismo

eucarioto, 16

procarioto, 16

predição de genes

ab initio, 13

abordagem

extrínseca, 13

intrínseca, 13

probabilística, 13

divisão do problema, 13

programa de predição

Augustus, 22

GeneMark, 34

Genemark.hmm, 22

Genie, 22

Genscan, 13, 22

GlimmerHMM, 22

Phat, 22

Tigrscan, 22

Twinscan, 13

razão log-odds, 15

região codificadora, 17

região não-codificadora, 17

regra de decisão de Bayes, 17

sensores

de conteúdo, 14

composição de códons, 16

freqüência de hexâmeros, 16

o conteúdo GC, 16

periodicidade de bases, 16 de sinais, 14

simulação, 29

sinal biológico

ponto de ramificação, 7

região promotora, 14

sítio aceitador, 7

sítio de fim de tradução, 8

sítio de início de fim de tradução, 14

sítio de início de tradução, 8, 14

sítio doador, 7

sítios de splicing, 14

seqüências conservadas, 14

sinal de poliadenilação, 6, 10, 14

tradução, 8

transcrição, 6 